\title{
مفهوم الإبداع في النسقية الإسلامية
}

عبد القادر هاشم رمزي

المقدمة:

إن أي رؤيـة إسـلامية تستكمل شـروط النسبة إلى الإسـلام لا بـــ أن تـرتبط بالنسـق المرجعي الإسلامي؛ أي المرجعية الإسـلامية في تحديد المفاهيم وتحقيق إسـلاميتها و تأصيلها. 1 وإن صحة الرؤيـة

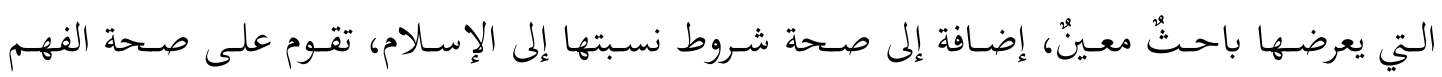
والتفسير والربط بين محورين، أولمها: النسق المفهومي لهذه الرؤية موضوعاً ودلالةً وصيغةً، وثانيهمـا: المرجعية الإسلامية المتمثلة في القرآن الكريم والسنة النبوية الشريفة، والدلالات المعجمية للغة العربية. ولعل مفهوم الإبـاع الإسـلامي لم يستثر انتباه فقهاء الأمسة الإسلامية وعلمائها وباحثيها في العصسور السـابقة -ربمـا- لأن دلالات هـذا المفهوم متضـمنة في مفـاهيم نسـقية إسـلامية أخـرى مثـل: العبادات، والطاعة، والالتزام، والإحسـان، والإتقـان، والعدالة، والاجتهاد، والجهاد، والتقوى، والورع، والبِدِعة الحسـنة، والابتـاع المهتدي؛ كَحُبِّ الله سبحانه وتعالى، وحبب رسوله عليه الصلاة والسـلام، وحب المؤمنين، وغيرها من مفاهيم الفعل الإسلامي وصور أدائه على الوجه الإسلامي. وقد برز تفعيل

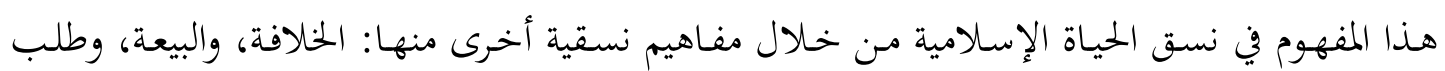
العلم. وعبر جهود علماء الإسلام، وفي تنظيم مؤسسات الحكمم والحسبة والوقف وتدوين الدواوين، وفي إنجازات القادة والولاة والفقهاء في جميع مناحي الحياة الإسلامية..

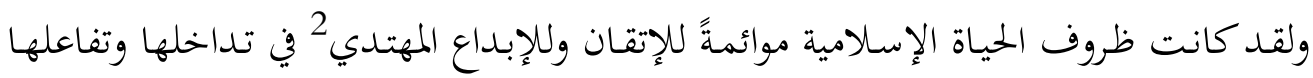

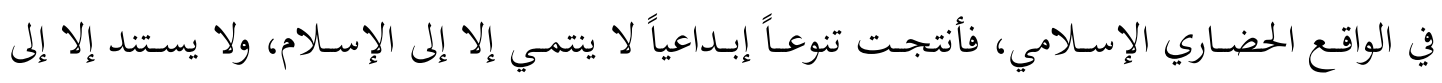

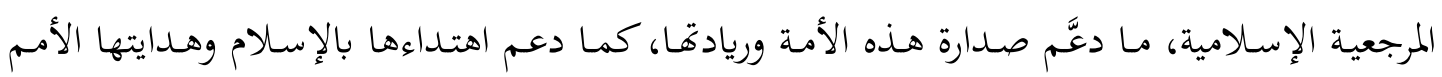
الأخرى إليه. وقد أغنى ذلك كله الباحثين والعلماء والفقهاء والمربين المسلمين، في ظل تلك الشروط، عن الانشغال المفهومي التفصيلي بالإبداع الإسلامي أو بالإبداع في الفعل الإسلامي وفي نطاق النسقية

aqhramzi@asu.edu.jo دكتوراه في العلوم الاجتماعية والتربوية، أستاذ مشارك في جامعة العلوم التطبيقية الخاصة في الأردن.

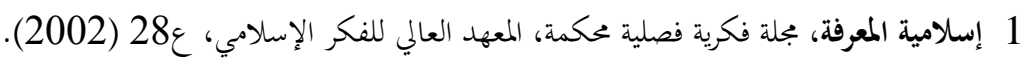

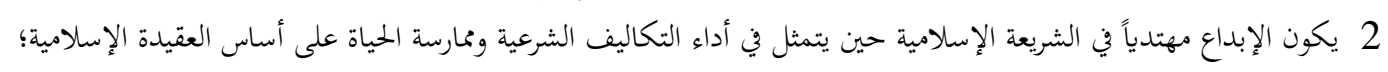

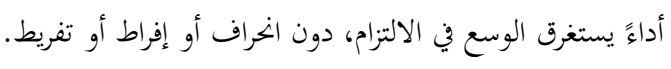


الإسـلامية3 الـتي ينتظم فيهـا: الإيمـان، والعقيـدة، والحيـاة الإسـلامية، والتربيـة الإسـلامية، والحضـارة الإسلامية.

ويرتبط الإبداع الإسلامي بالواقعية المرجعية التي تستند إليها الرؤية المفهومية الإسلامية لهذا

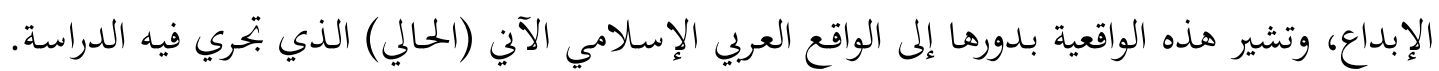

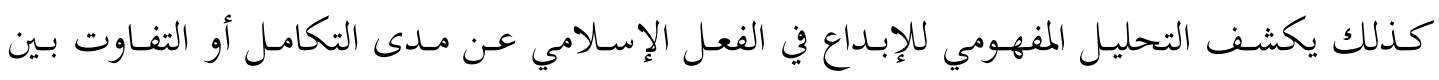

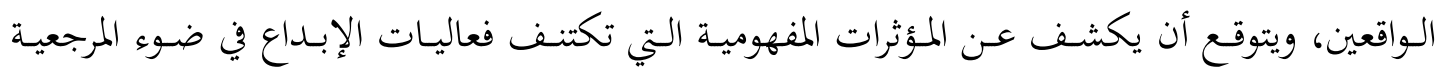

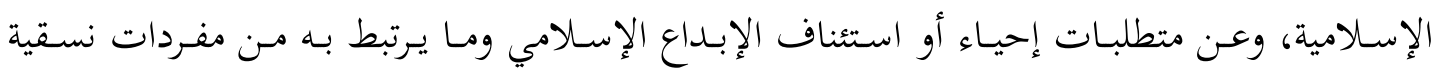

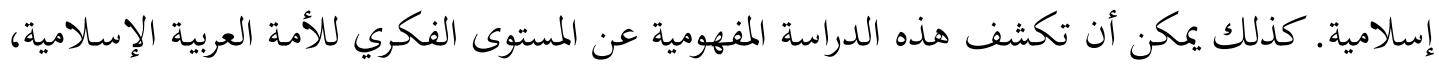

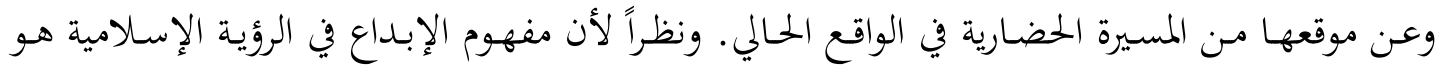

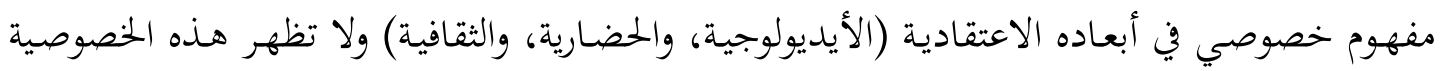

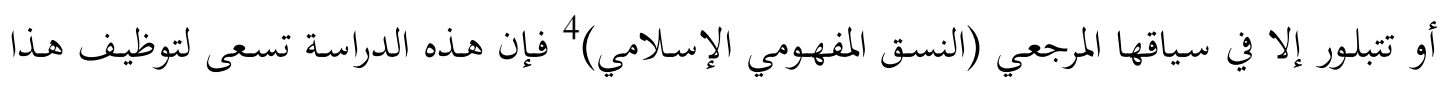
الارتباط بين الإبداع الإسلامي والنسقية الإسلامية.

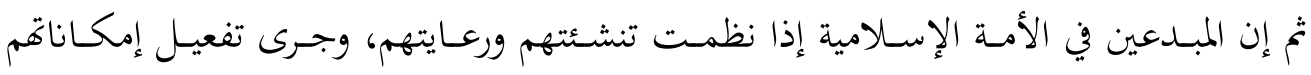

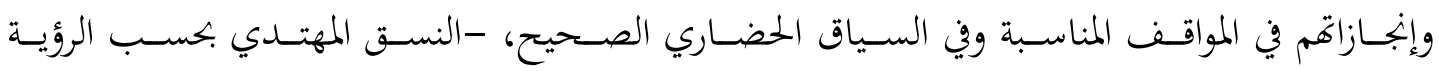

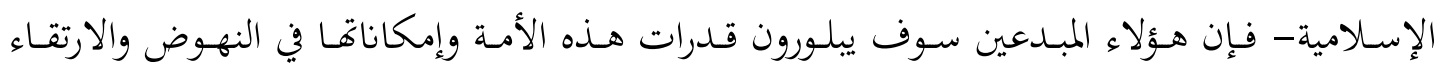

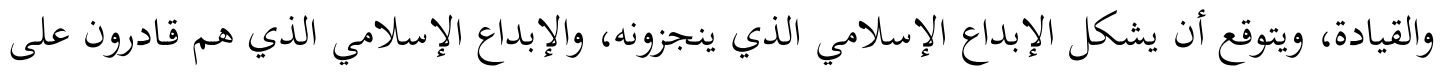

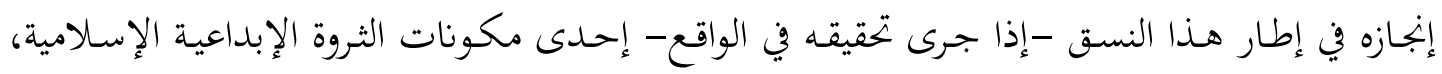

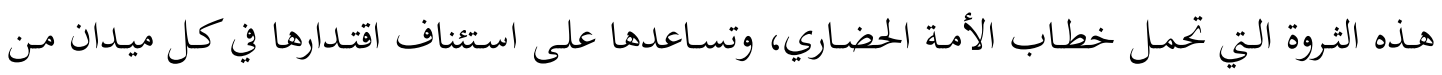

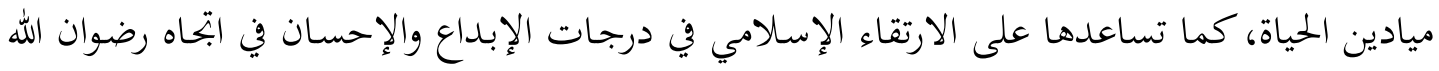

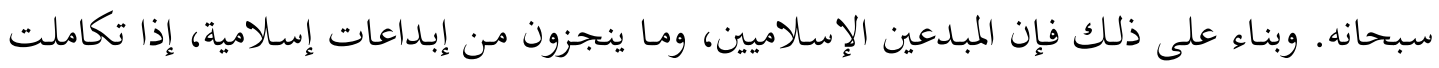

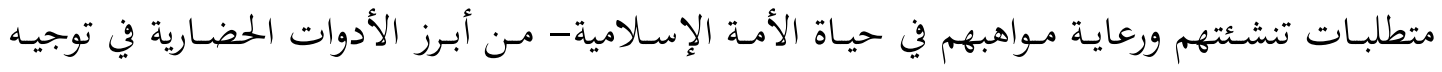

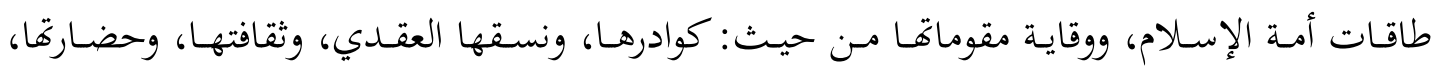

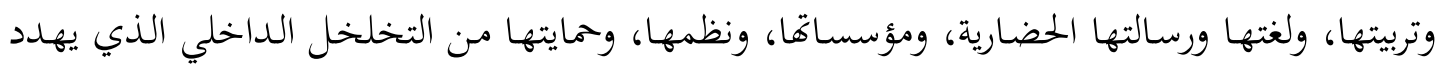


بناها الأساسية، ومن التغلغل الخارجي الوافد (الغازي) الذي يهدد كياها ومسيرتا ورسالتها الحضارية، إضافة إلى تمديد اقتدارها على التجدد والارتقاء والتميز. وهذه الدراسة محاولة تحليلية لبلورة مفهوم الإبداع الإسلامي من جهة نسقيته، وتوضيح الثوابت

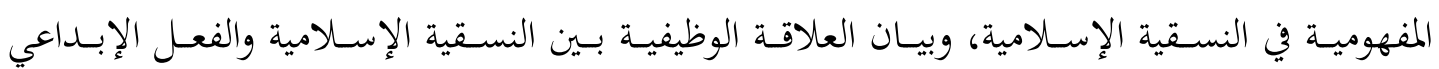
الإسلامي، ومتطلبات تفعيل الإبداع الإسلامي في حياة المسلمين. وتنحصر الدراسة في مفهوم الإبداع

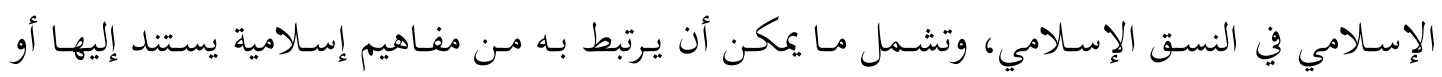

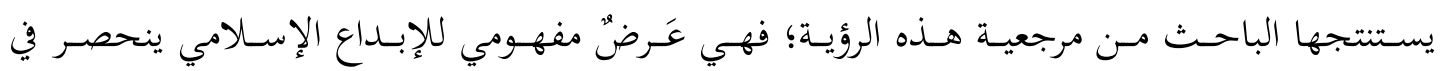

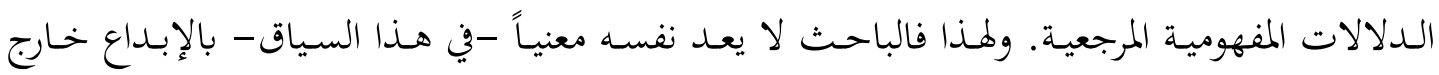
النطاق الإسـلامي، وإن كـان يقـترب منـه في ظل تفعيل النسـق المرجعي الإسـلامي وإمكانيـة تطبيقه، ومتطلبات هذا التفعيل في الواقع. والنسق في الرؤية الإسلامية هو منظومة المفاهيم التي تحققت إسلاميتها (نسبتها إلى الإسلام) أصالة5 أو تأصيلاًك، ولا تحمل هذه الصفة إلا المصطلحات التي تنتظم في نسيج النسقية الإسلامية

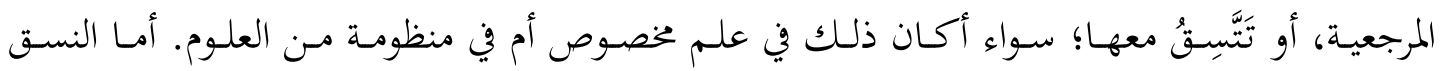
الإسلامي المرجعي، أو الإطار المرجعي للنسقية الإسلامية فيعني: منظومة المفاهيم والمفردات التي تتكون منها العقيدة الإسـامية بشقيها: التصديق القلبي الجـازم، والتصديق العملي المرتبط بـه. فـالأول هـو: (الإيمان)؛ أي الاعتقـاد (الجـازم) بالله، وملائكتـه، وكتبـه، ورسـله، واليوم الآخـر، وبالقـدر خـيره وشـره؛ ويقوم عليه الجانب الثاني (الإسلام) وهو: شهادة أن لا إله إلا الله وأن محمداً رسول الله، وإقام الصلاة، وإيتاء الزكاة، وصوم رمضان، وحج البيت من استطاع إليه سبيلاً. 7 وكل مـا يرتبط بهذه المفردات من الأفعال الإسلامية، وما يقوم عليها قياماً إسلامياً من مفاهيم نسقية إسلامية.

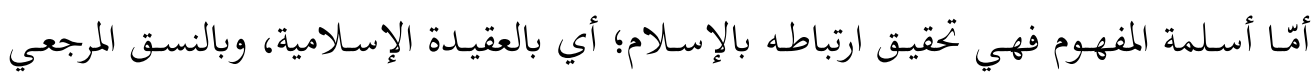
الإسلامي في الحياة الإسلامية نظراً وعملاً أو فقهاً وتطبيقاً، ويشمل ذلك إسلامية ما ينتج عن تطبيق

5 رمزي، عبد القادر . "في النسق المفهومي الإسلامي: البعد الاجتهادي في التنظير والتأصيل"، مجلة البلقاء للبحوث والدراسات،

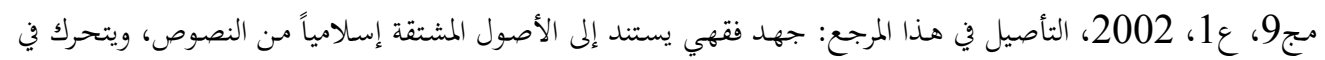

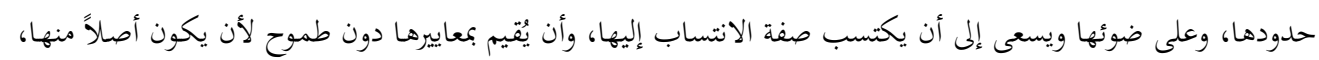

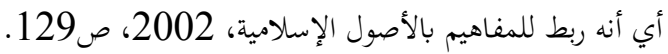

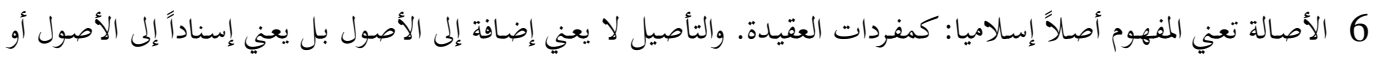

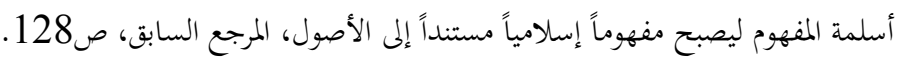

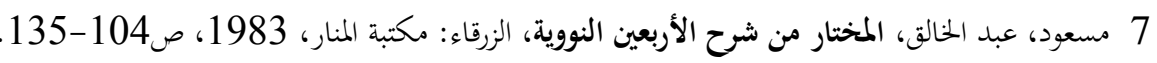


المفهوم من آثار إسلامية مققة مادية ومعنوية. 8 وهذه الأبعاد تؤخذ في الحسبان عند التحقق من عملية الأسلمة، كما أها عملية اجتهادية بالمعنى الفقهي الإسلامي.

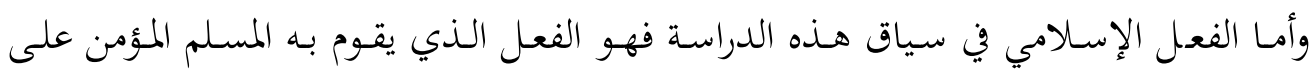

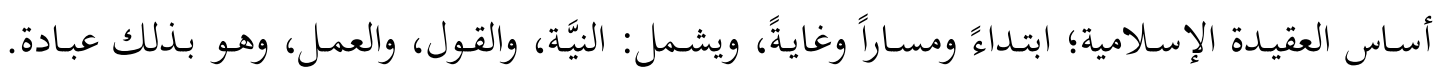

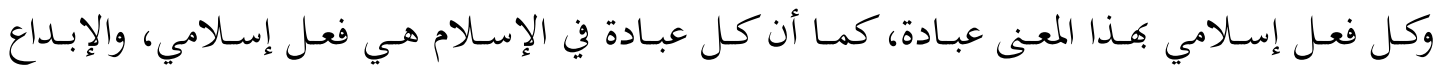

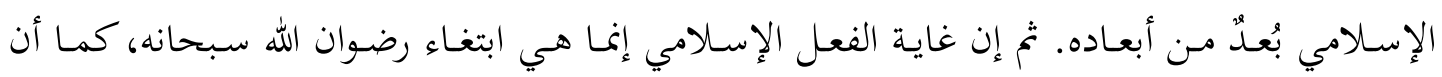

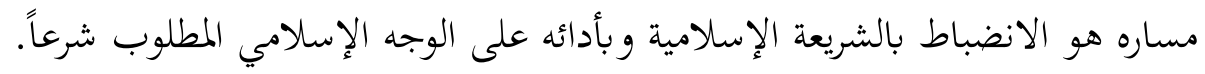

أولاً: الإبداع في الدراسات الإسلامية السابقة:

من الدراسات الإسلامية السابقة التي تناولت الإبداع في أبعاده الإسلامية بصورة أو بأخرى:

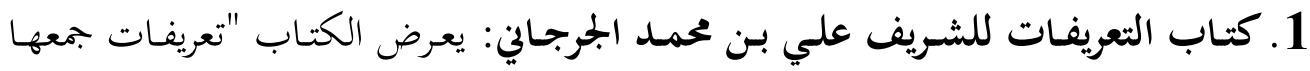

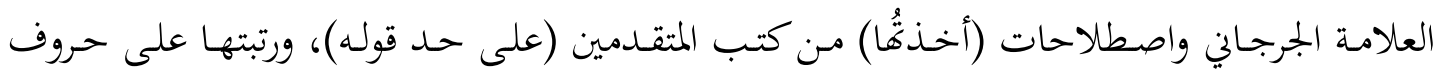

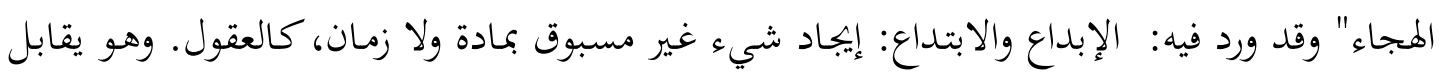

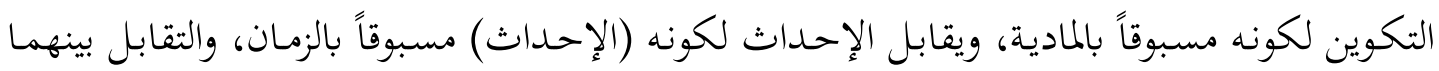

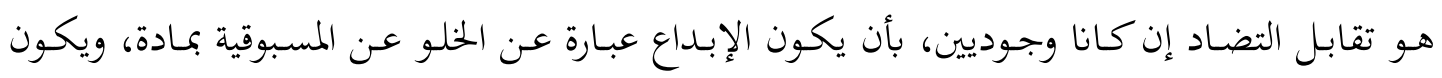

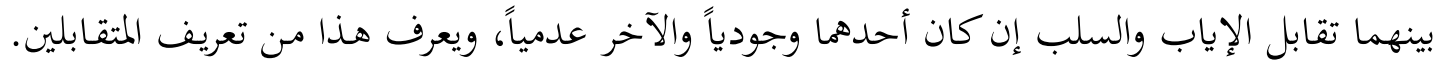

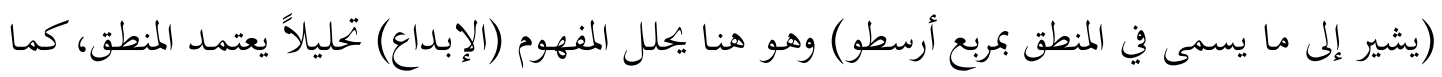

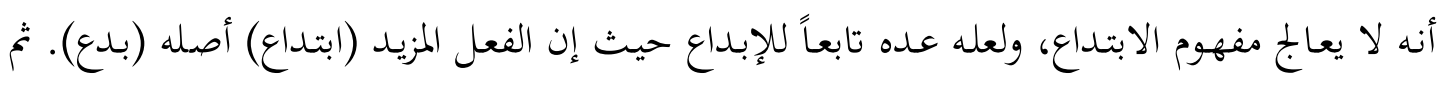

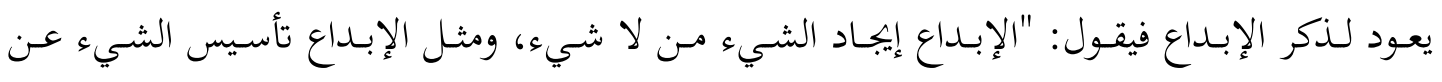

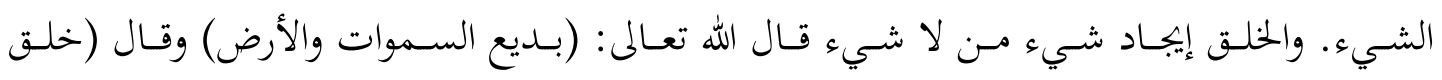

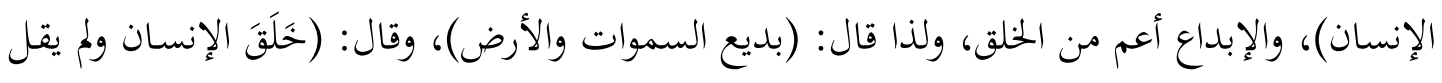

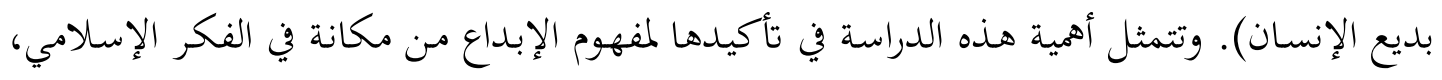
غير أهما تبقى دراسة معجمية لا تتناول الأنساق الفكرية أو التطبيقات الوظيفية الإسلامية للمفاهيم.

8- أبو سليمان، عبد الحميد. الإنسان بين شريعتين،رؤية قرآنية لمعرفة الذات ومعرفة الآخر، إسلامية المعرفة، المعهد العلمي

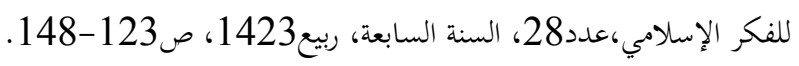


2. مقدمة في منهج الإبـداع - لزهير منصسور: قدمت هذه الدراسة منهجية الإبداع دون

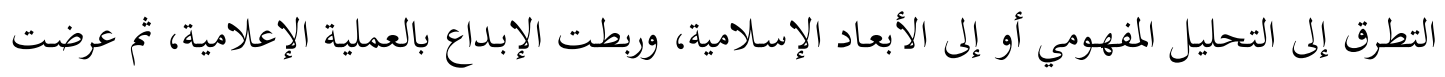

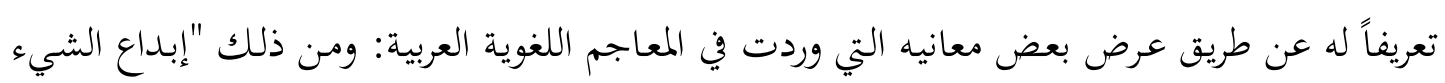

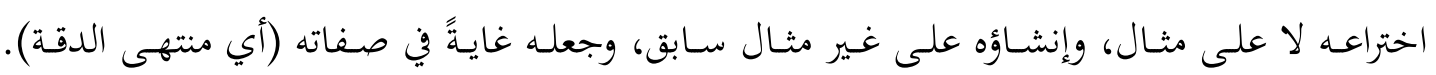

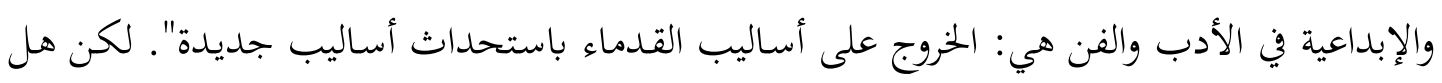

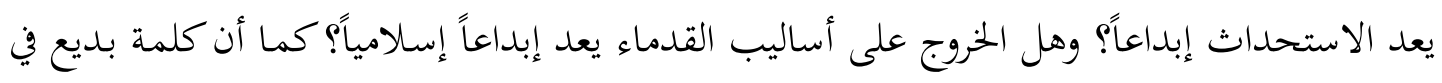

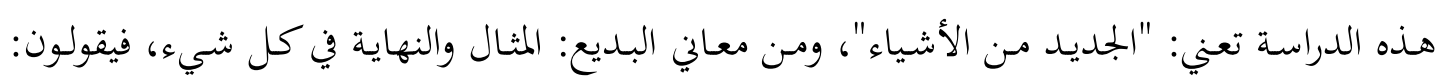

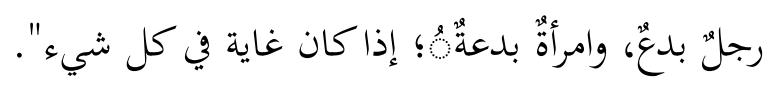

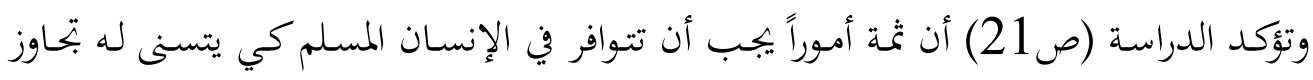

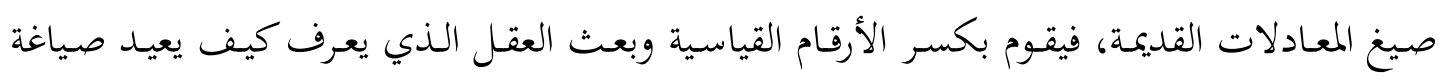

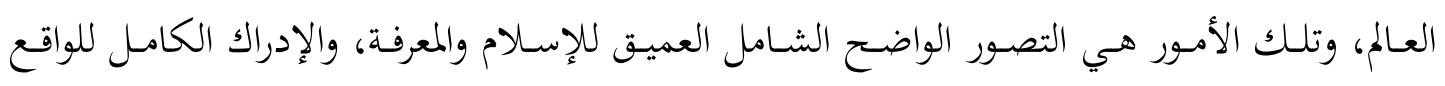

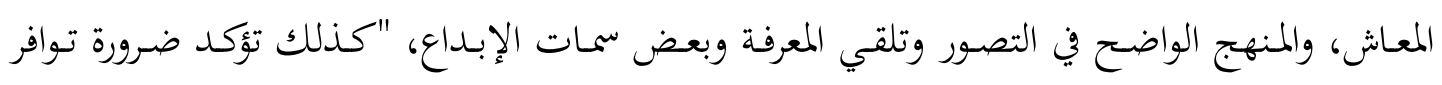

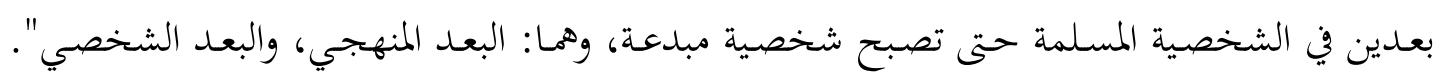

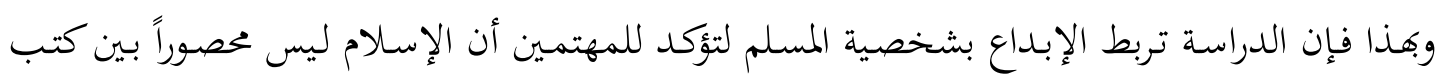

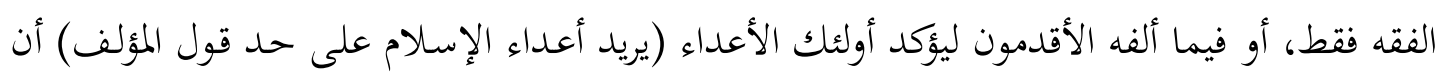

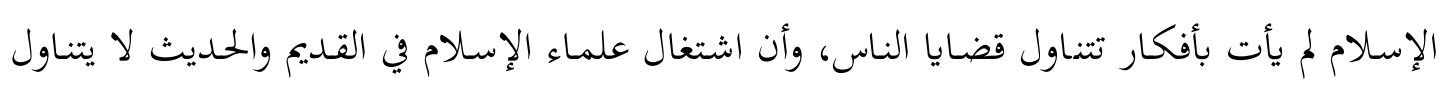
إلا العبادات.

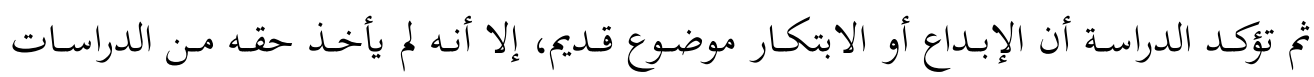

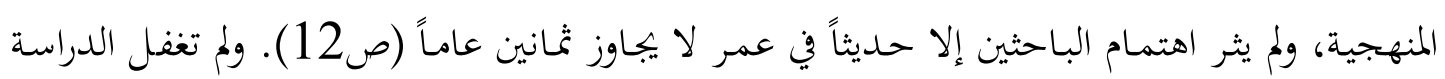

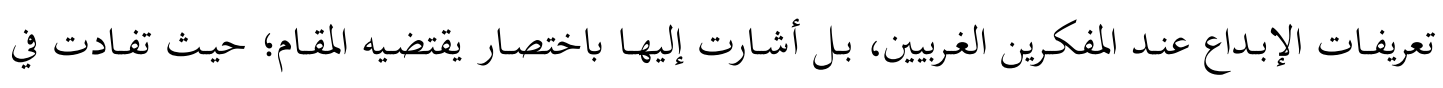

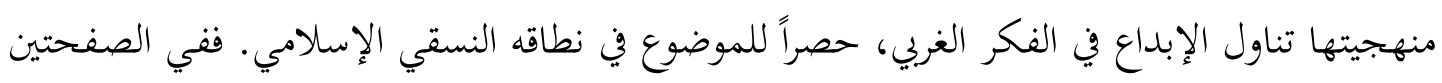
(26، 27) تشير إلى تعريفات مفكرين غير إسلاميين، يمكن اقتطاف أمثلة من بينها:

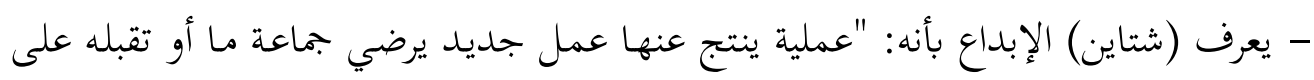

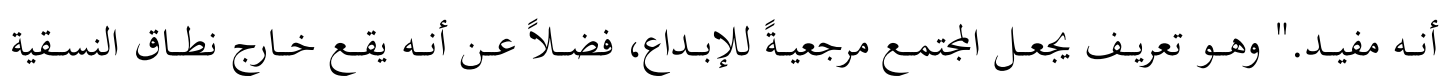
الإسلامية. 
- ويعرفه (سيمسون) على أنه: "المبادرة التي يبديها الشخص في قدرته على الانشقاق من التسلسل العادي في التفكير إلى ما يخالف فيه النمط المعتاد."

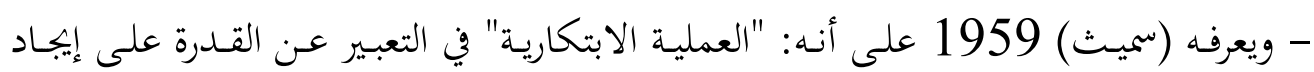
علاقات بين أشياء لم يسبق أن قيل إن بينها علاقات.

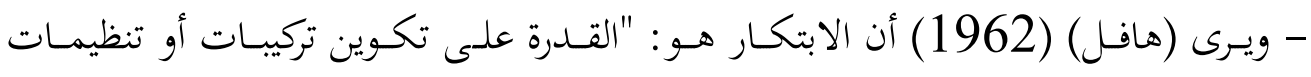
جديدة."

- ويرى (ثوراندايك) أن الإبداع ظاهرة يمكن حصرها في فئات أربع هي: التعريفات التي تركز

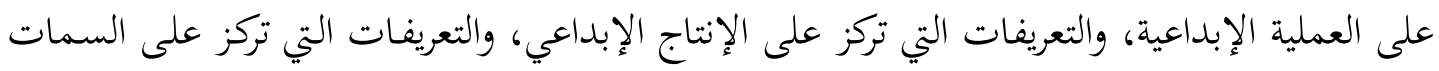
الإبداعية (الشخصية)، والتعريفات التي تركز على الإمكانية الإبداعية.

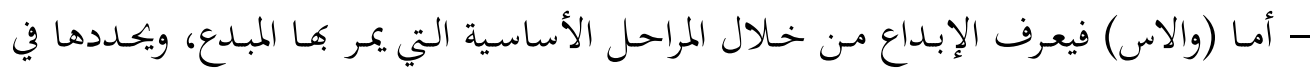

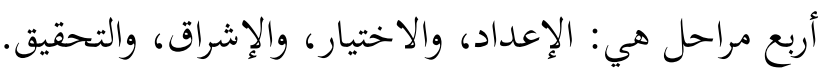

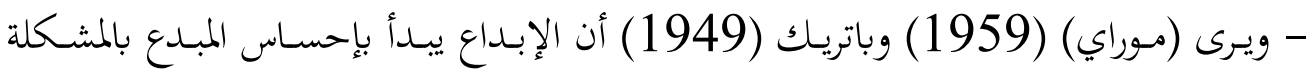
ليمر بمراحل الإبداع التي وضعها والاس.

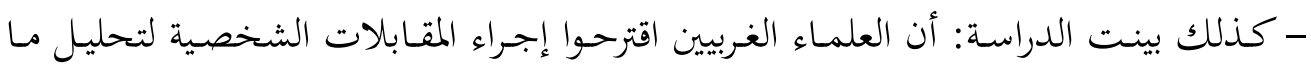

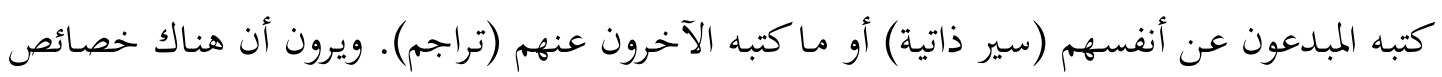

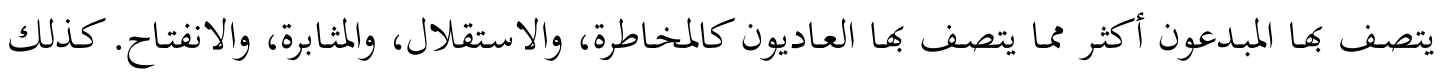

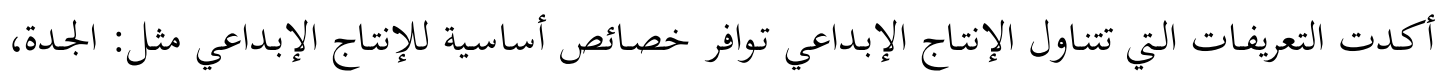
والملاءمة (المواءمة) وإمكانية التقدير.

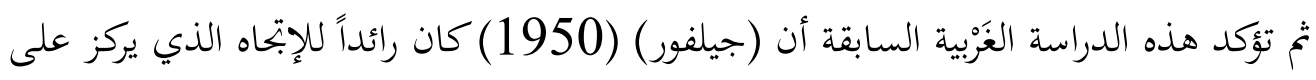

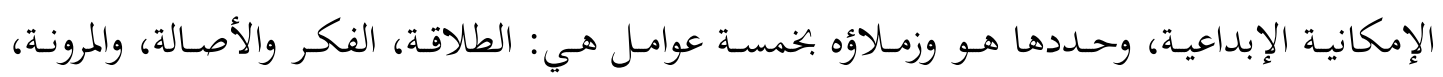

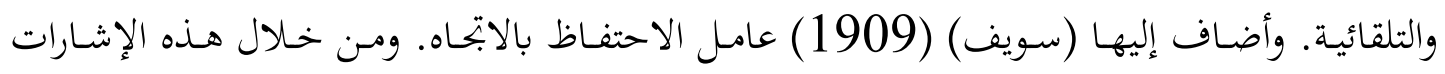

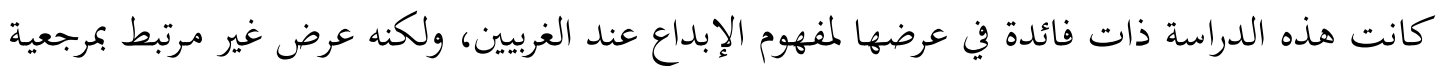

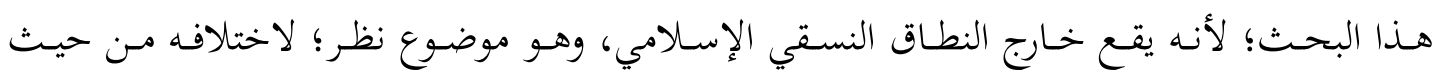

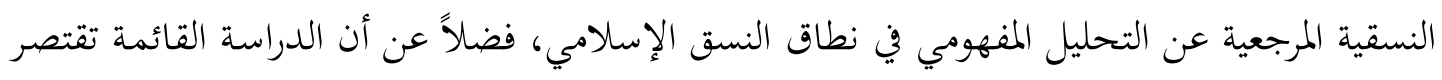

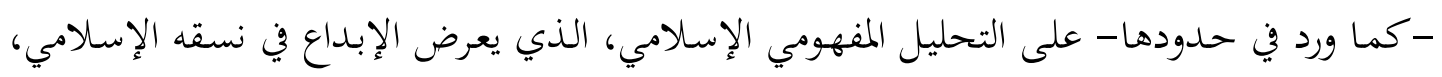


الذي يسعى به المبدع إلى بلوغ مرضاة الله سبحانه وتعالى، وهو الحمد الذي يكون فيه الإبداع عبادة إسلامية.

ومع أن الدراسة السابقة المذكورة في هذه الفقرة قدمت اختبارات قياس الإبداع، كما قدمت الفات

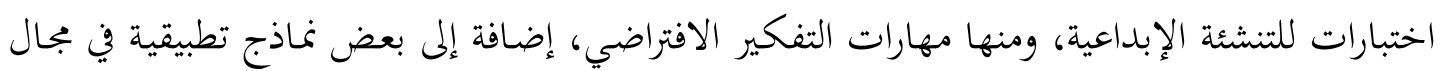

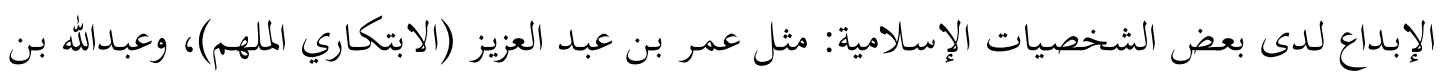

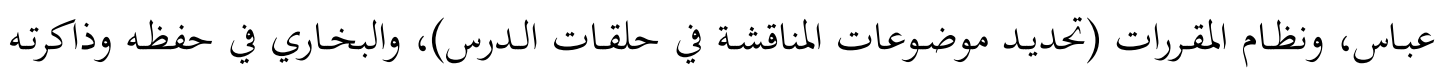

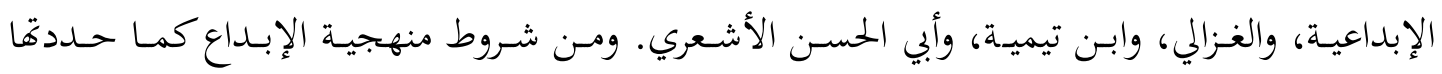

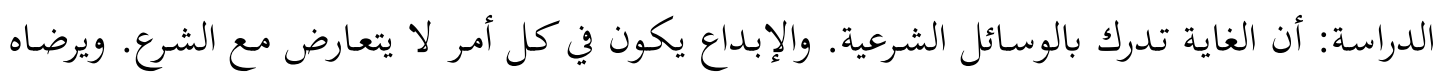

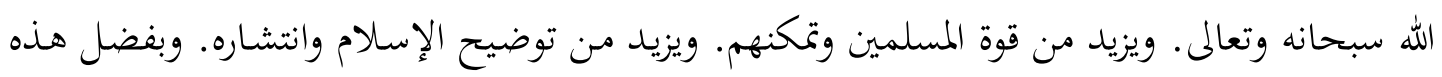

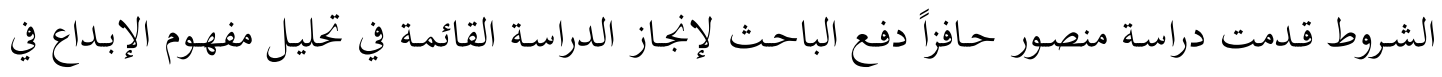
النسق الإسلامي.

3. الدين والإبـداع: دراسة فلسفية (أثر العقيدة في منهج الفن الإسلامى مـن خلال محاور

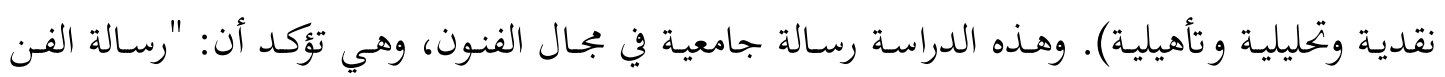

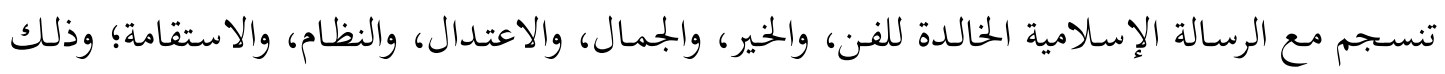

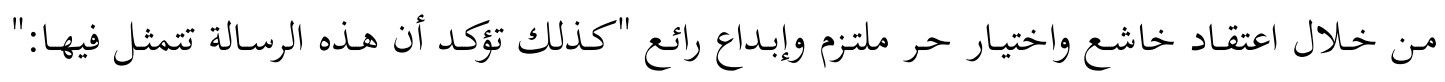

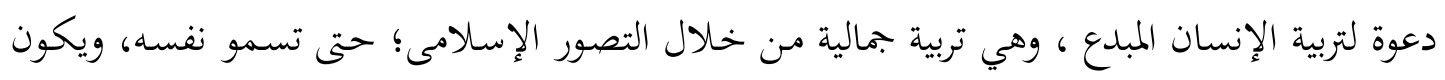

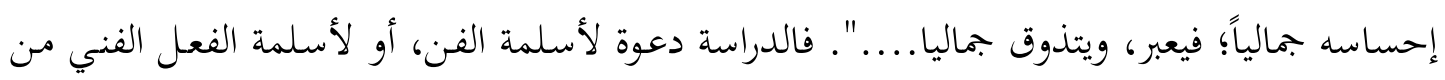

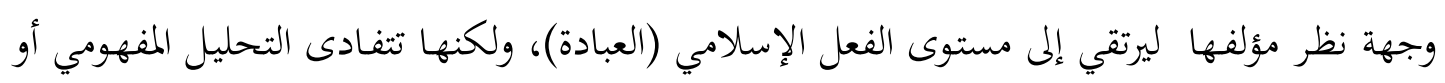

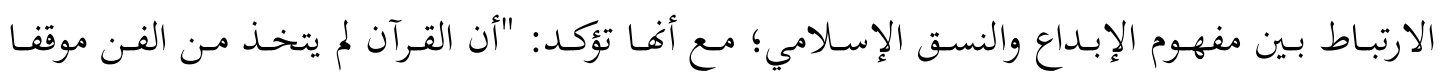

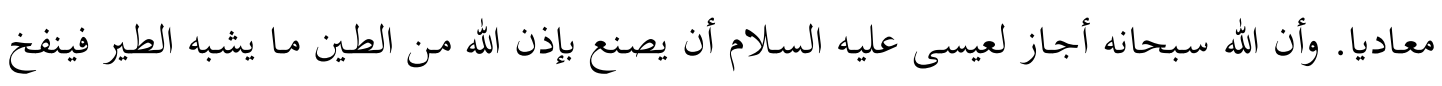

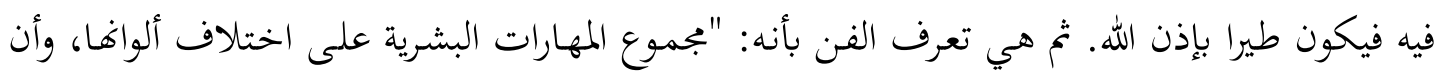

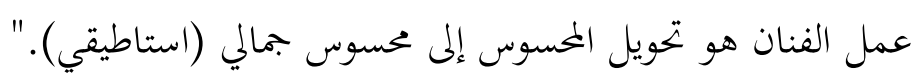

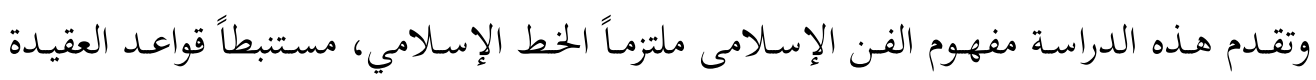

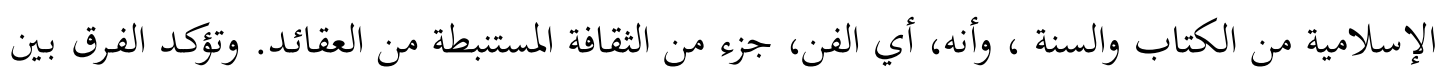

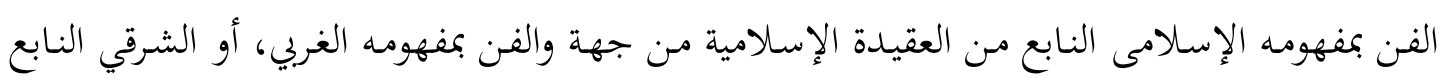

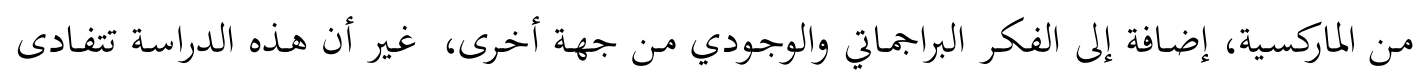


التحليل النسقي المهتدي؛ فتركز على موقف الأديان من الوثنية، وموقف علماء أصول الفقه منها. ثم

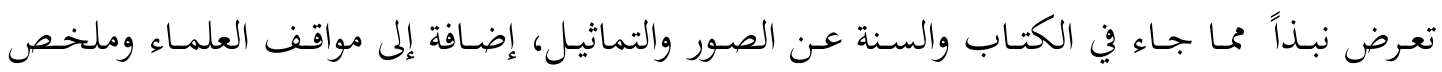

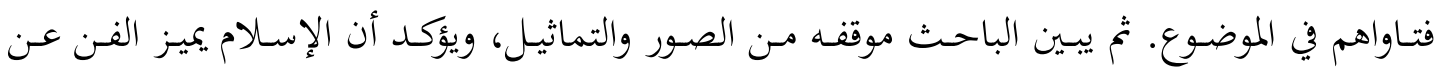

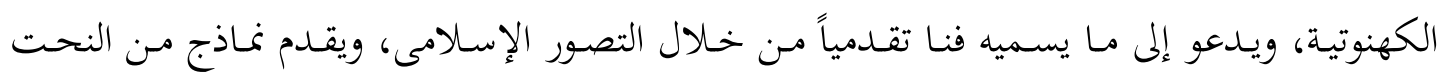

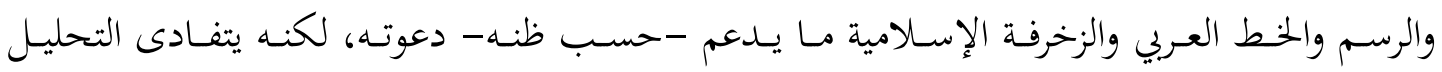
المفهومي للإبداع في النسقية الإسلامية.

4. الإبداع في الفنون والعلوم، للدكتور عبد الكريم اليافي: فقد استخدمت هذهة الإسية الدراسة

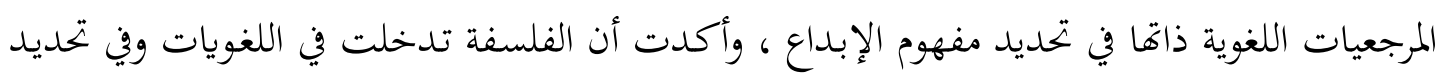

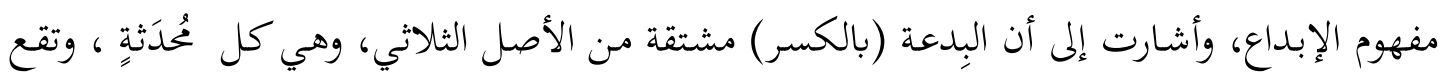

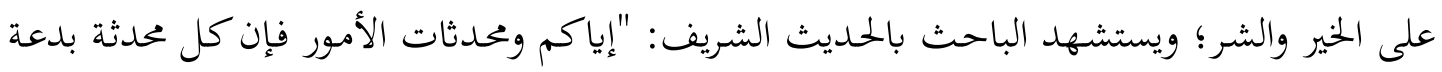

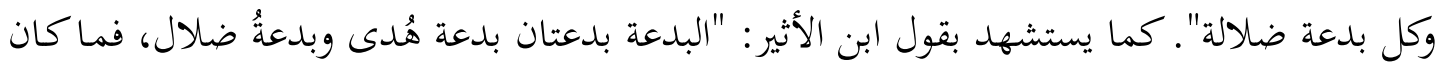

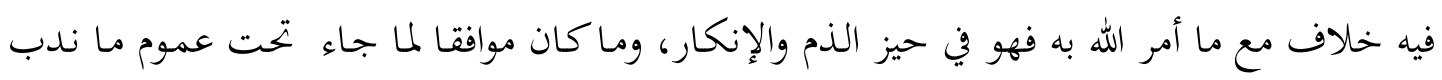

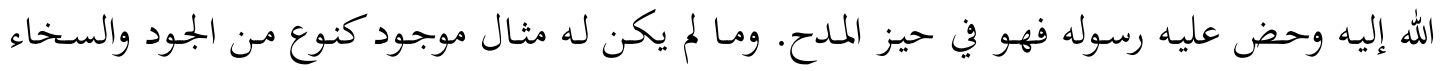

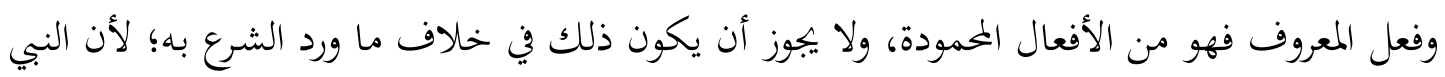

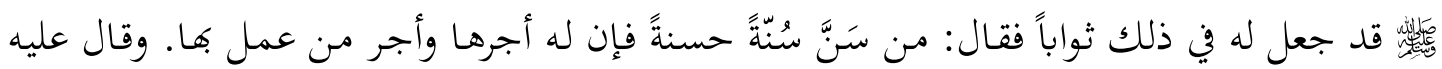

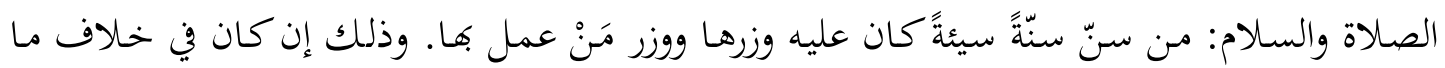

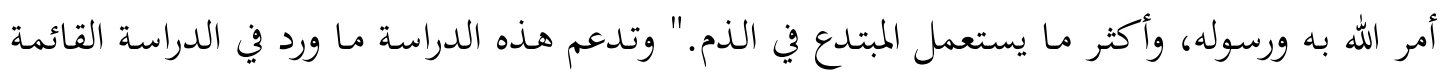

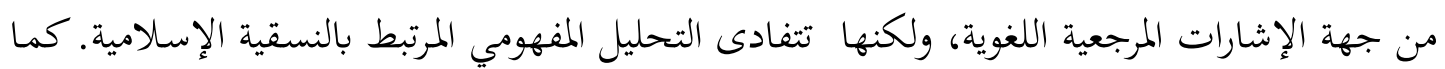

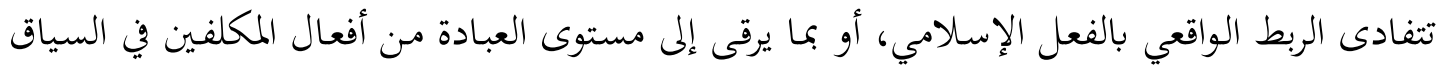

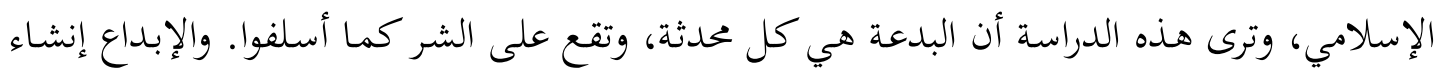

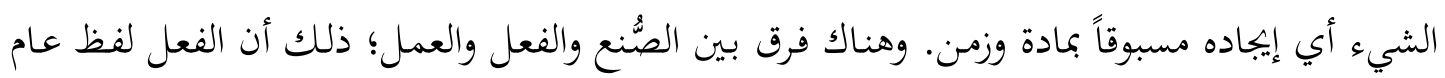

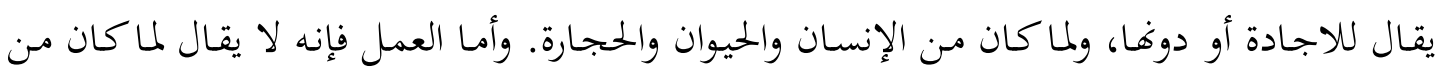

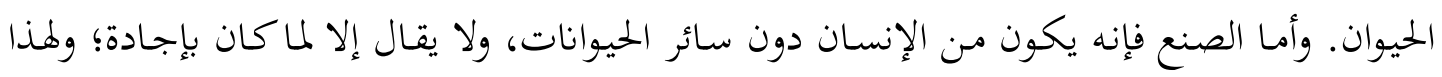

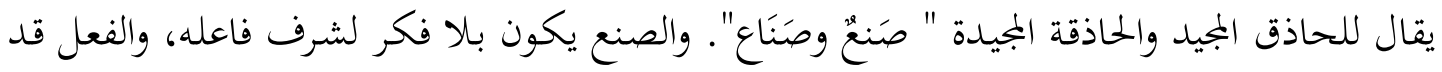

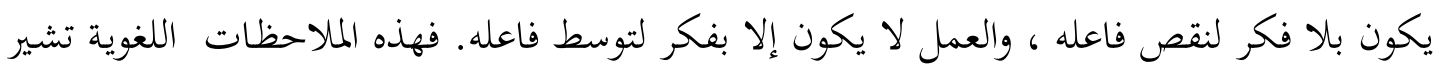

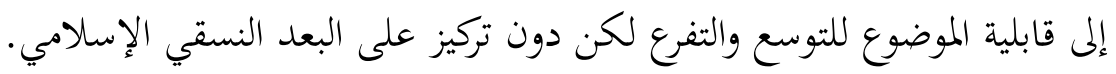


ومن المؤكد أن المنحى الرئيس في هذه الدراسة ليس التحليل المفهومي بقدر مـا هو التحليل

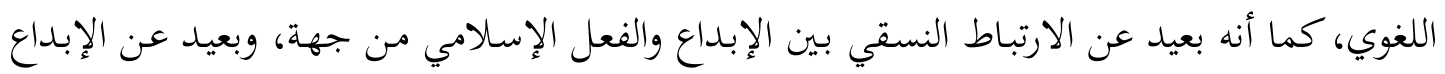
في الفعل الإسلامي من جهة ثانية .

5. عناصر الإبداع العربي، للدكتور عفيف بهنسي، ولا تتناول هذه الدراسة الإبداع العربي

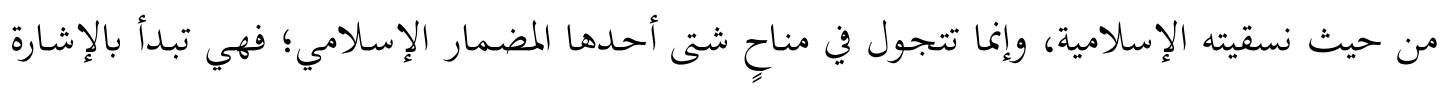

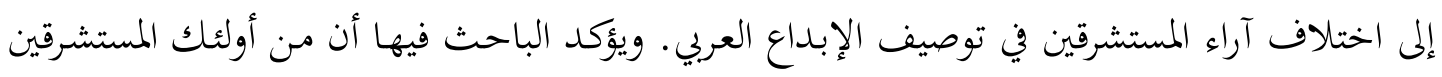

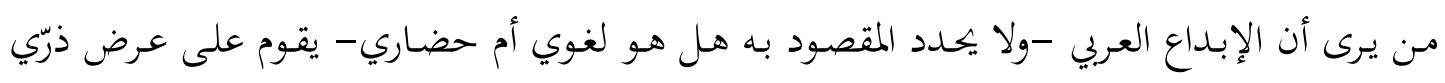

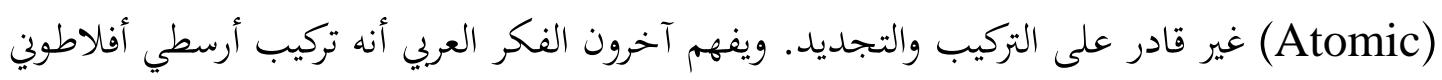

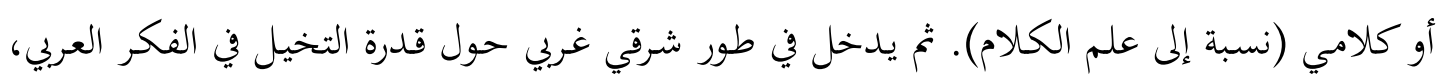

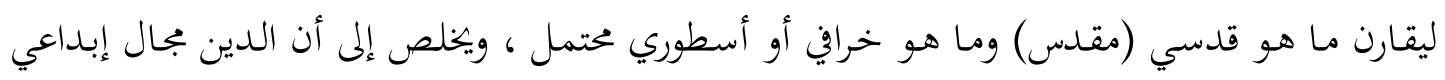

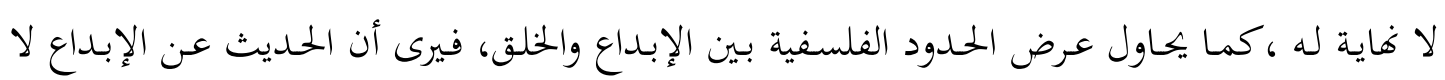

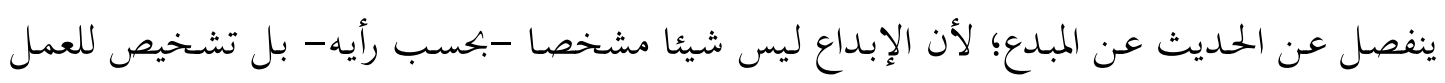

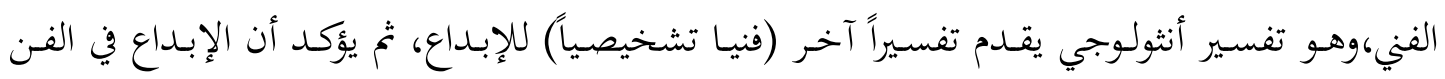

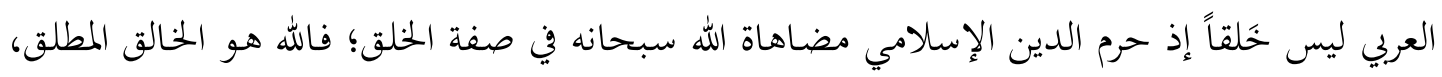

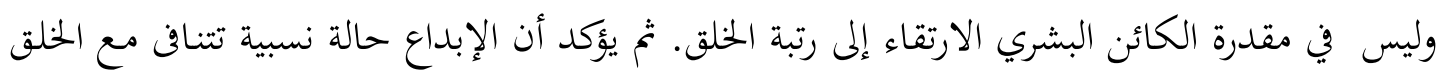

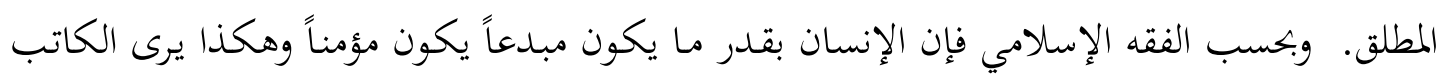

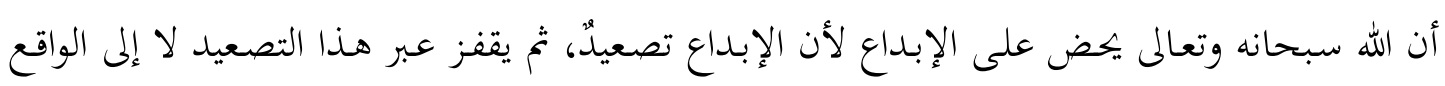

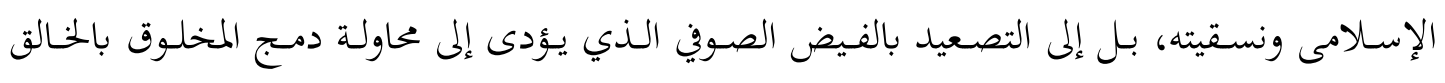

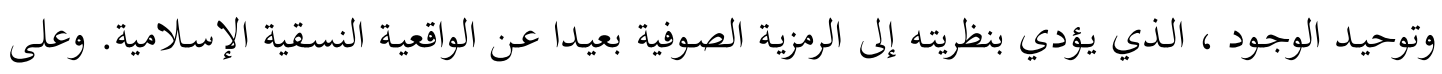

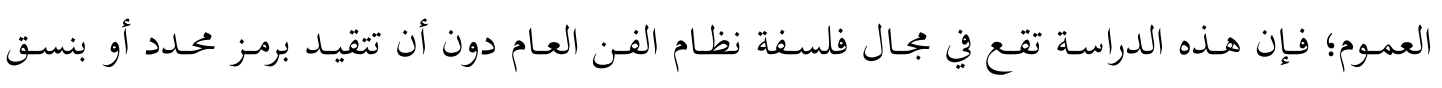

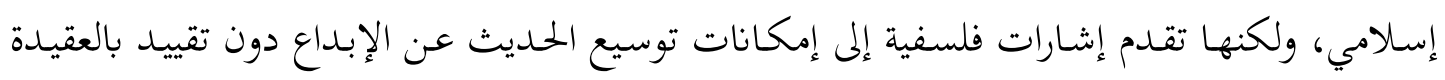
الإسلامية أو بالنسقية الإسلامية.

وبعد، فهذه نماذج من الدراسات السابقة حول الإبداع الإسلامي، لكنها لم تتوقف عند علاقة الإنة

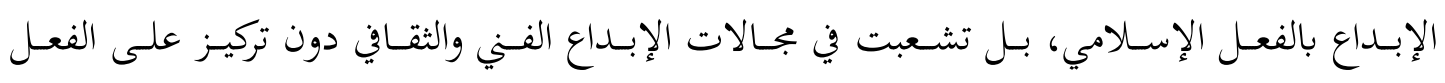

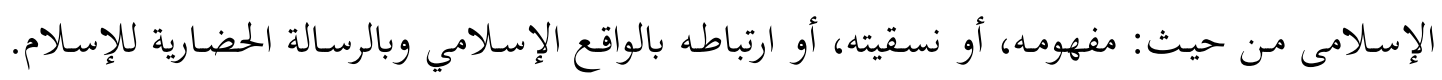


ولعل هذا البحث القائم محاولة لإنارة هذا البعد الذي نأت عنه الدراسات التي تناولت الإبداع في الفكر العربي، فلم تتناوله في إسلاميته الفكرية والفعليه أو في نطاق النسقية الإسلامية.

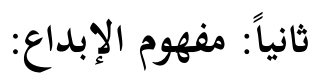

يدور السؤال الأول حول إمكانية عرض رؤية إسلامية لمفهوم الإبداع باعتباره وحدة منتمية

للنسق المفهومي الإسلامي، أو وحدة مفهومية يككن نسبتها إلى النسقية الإسلامية.

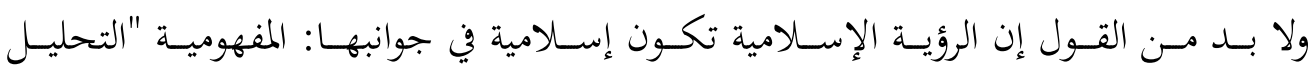

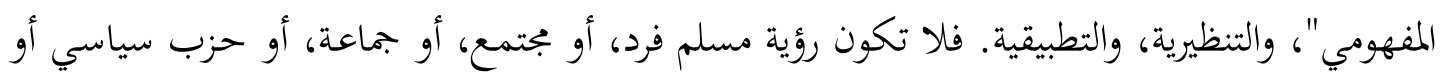

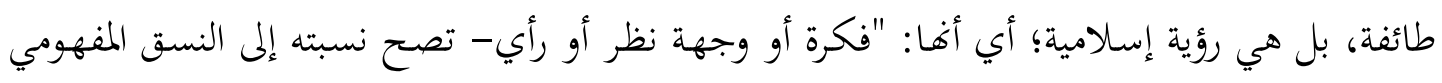

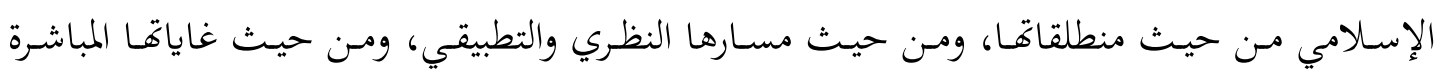

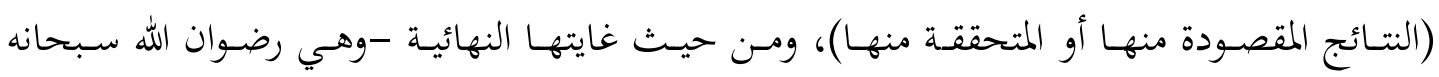
وتعالى - غاية الغايات."

وبذلك فكل فكرة، أو نية، أو عمل، أو نشاط، ينطلق من العقيدة الإسلامية، ويرتبط مساره

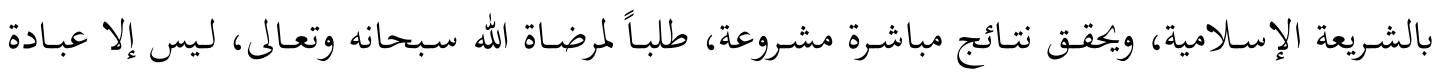

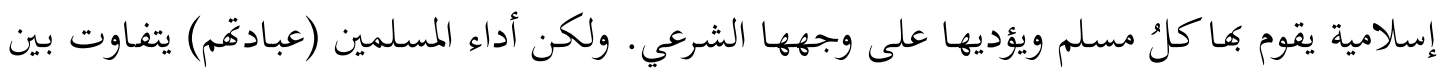

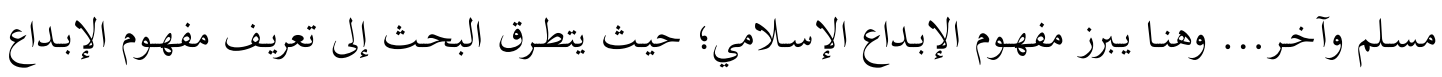

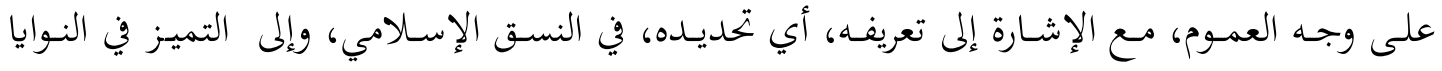

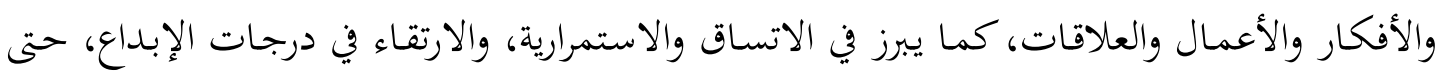

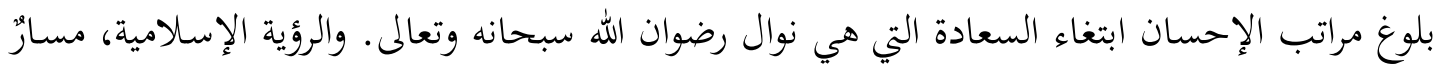

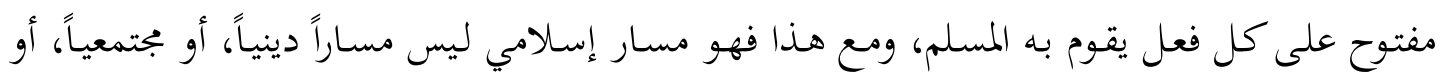

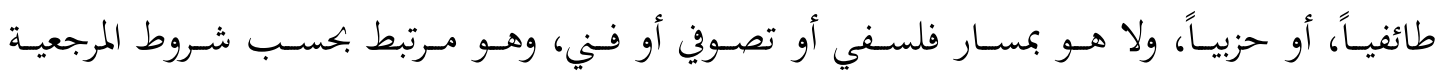
الإسلامية وحدودها المفهومية - إذا صح الاستنباط والتنظير والتأصيل، 10 بالشريعة الإسلامية.

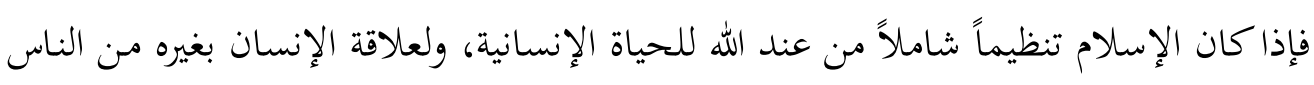

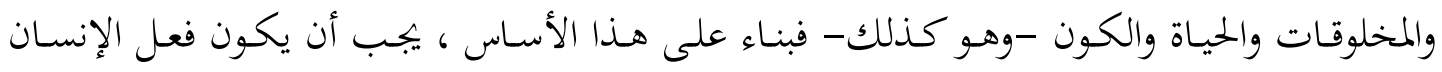

9 Ramzi, Abdul Qader (1940), Islamic Education In the Understanding of Present Day Muslim Educationists: (A view of the Concept of Islamic Education within Islamic context), University of Durham, p. 170.

10 رمزي، عبد القادر . "في النسق المفهومي الإسلامي: البعد الاجتهادي في التنظير والتأصيل"، مرجع سابق، ص103-135. 
المسلم إسلامياً، وكذلك إيمانه الذي يطلب منه أن يتقن أداءه ويبدع في التزامه وفي أداء كل عمل يقوم إنها

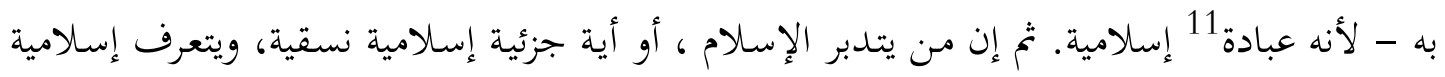

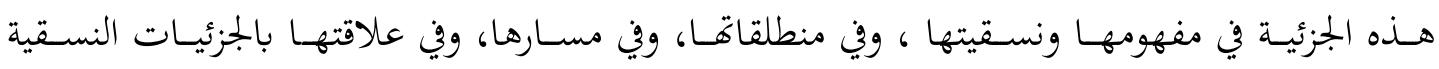

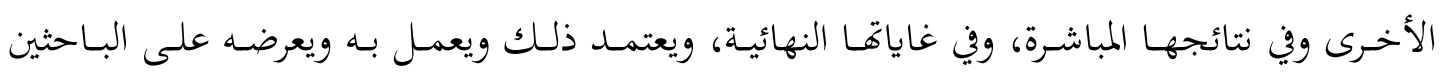

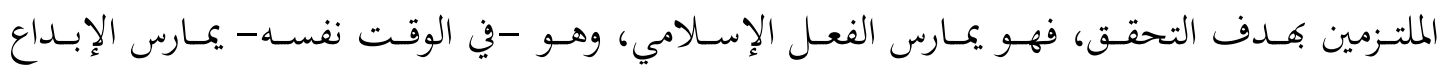
الإسلامي بقدر ما يحسن في ذلك كله .

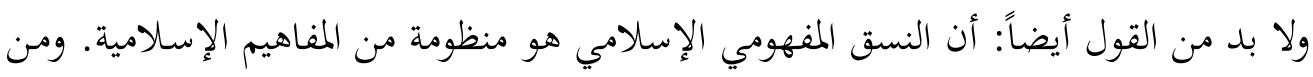

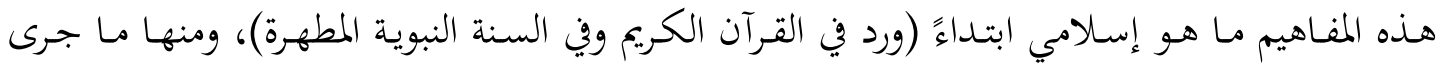

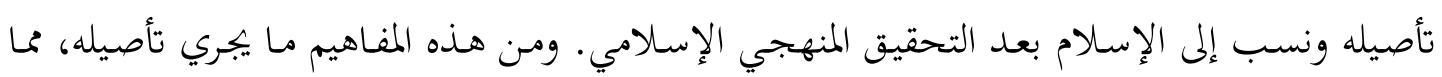

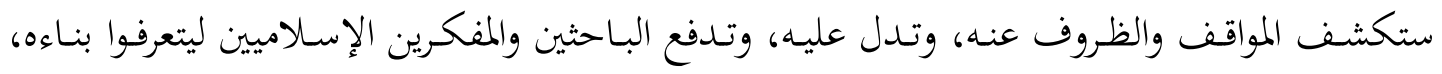

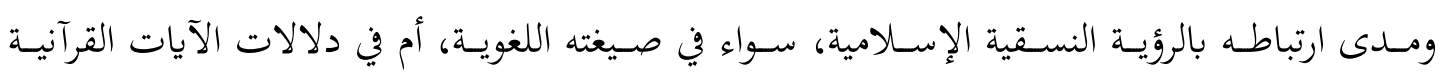

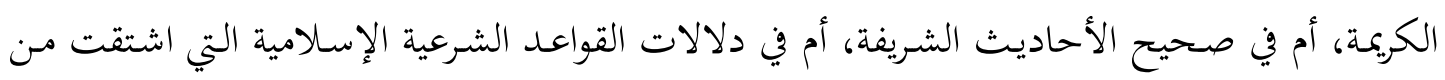

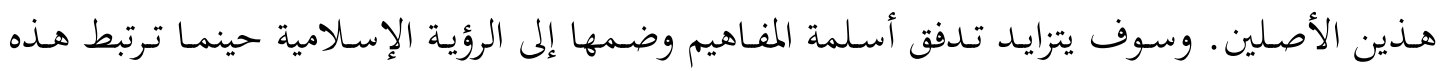

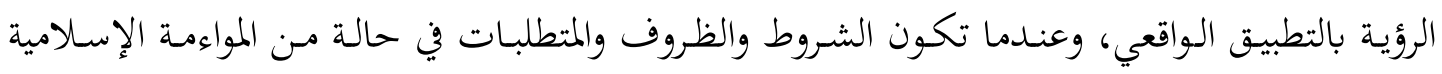

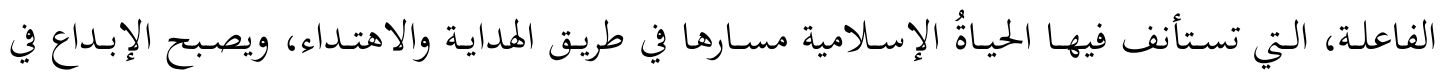
الفعل الإسلامي سمة إنجازية أساسية من سمات التوجه نحو مراتب الإحسان الإنسان ابتغاء مرضاة الله جلّ وعلا.

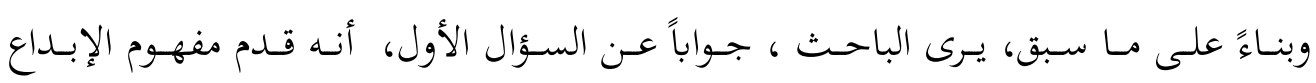

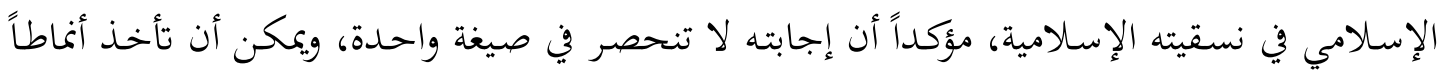

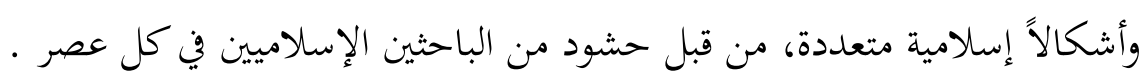

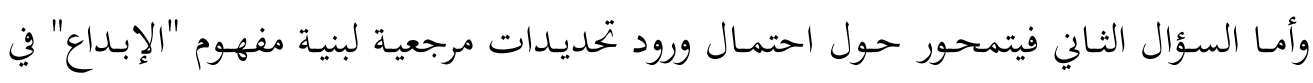

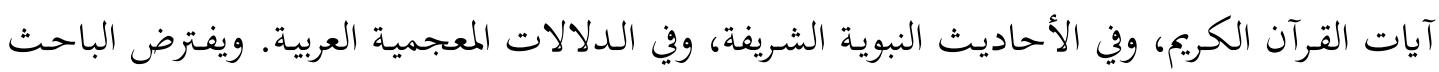

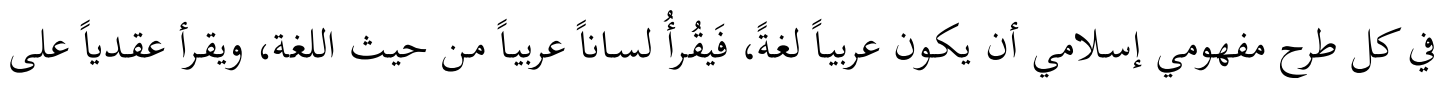

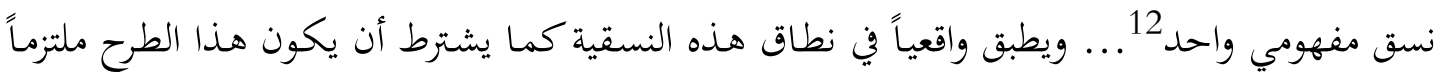

11 أبو سليمان، عبد الحميد. "إسلامية الجامعة وتفعيل التعليم العالي بين النظرية والتطبيق: الجامعة الإسلامية نموذجاً"، مجلة

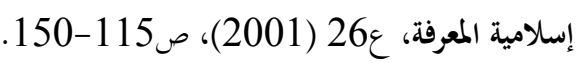

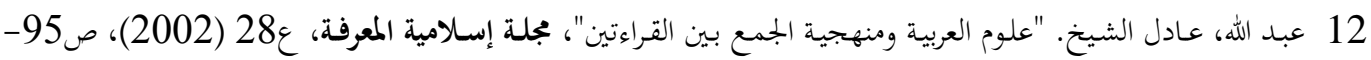


- بل مقيداً بالدلالة اللغوية العربية، ومستنداً إلى المرجعية الإسلامية المتمثلة في الآيات القرآنية العظيمة،

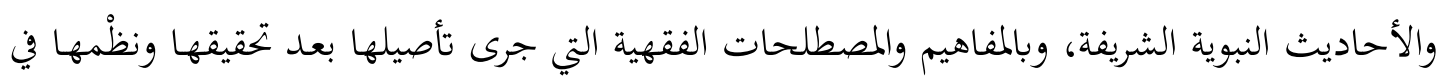

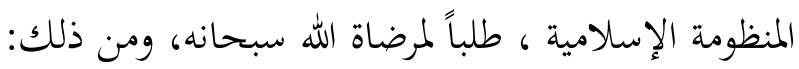

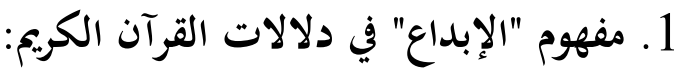

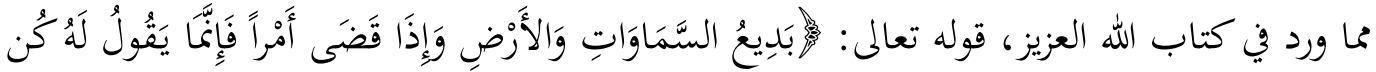

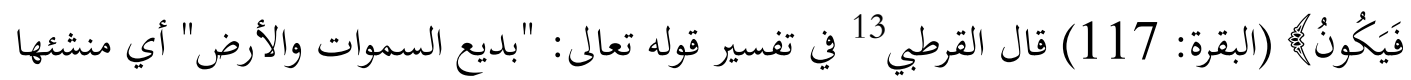

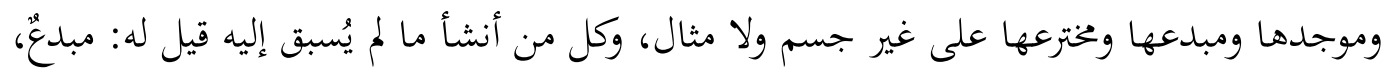

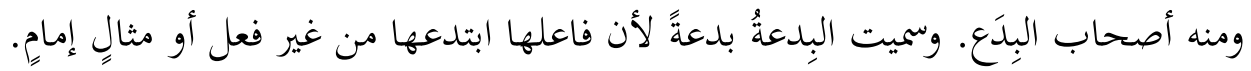

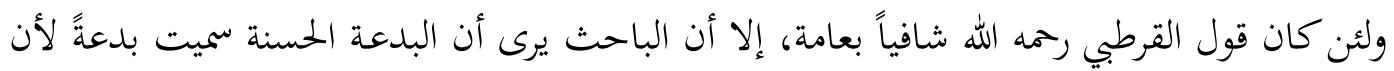

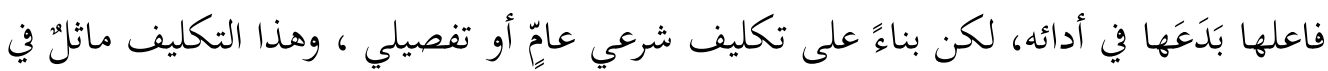

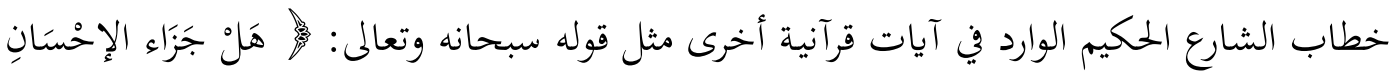

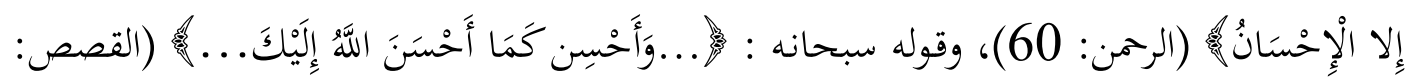

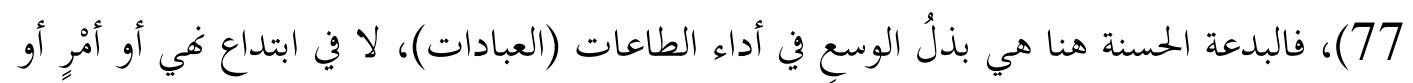

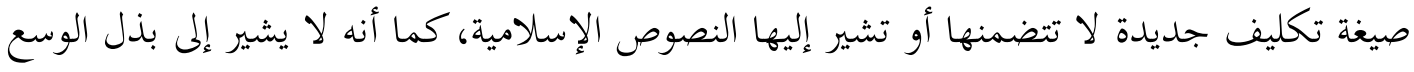

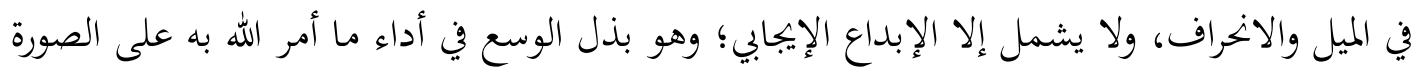

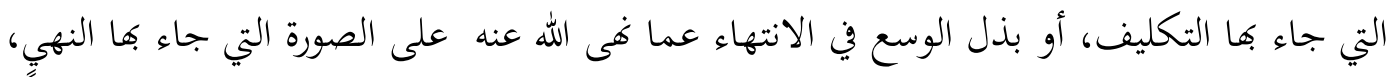
ويدخل في ذلك: الفقه، والاجتهاد، والتفقه، والعلم، والتعلم، والتعليم، والصناعة، والتجارة، وكل نشاط التهاء

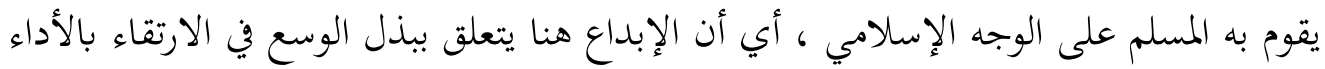

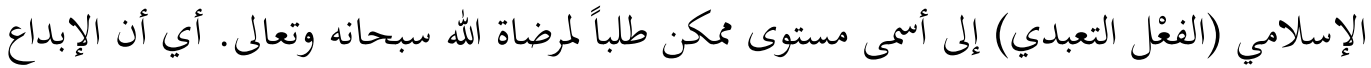

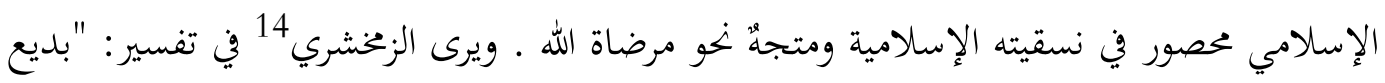

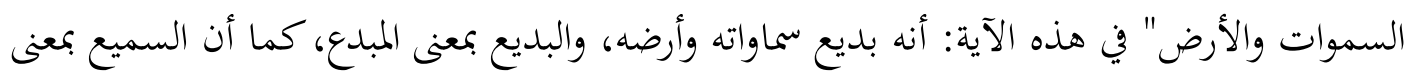

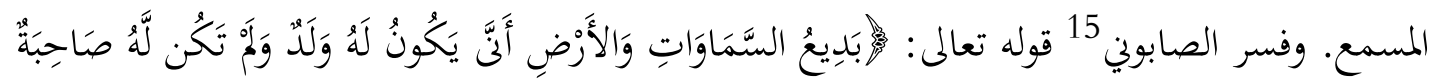

$$
\begin{aligned}
& 13 \text { القرطبي، أبو عبد الله محمد بـ مـد الأنصاري. الجـامع لأحكام القرآن، بيروت: دار الكتب العلمية، 1993، ج2، } \\
& \text { ص86. } \\
& 14 \text { الزخشري، أبو القاسم جار الله. الكشاف عن حقائق التنزيل وعيون الأقاويل في وجوه التأويل، القاهرة: مكتبة مصطفى }
\end{aligned}
$$

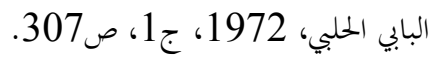

$$
\begin{aligned}
& 15 \text { الصابوني، محمد علي. صفوة التفاسير، الدوحة: مطابع الدوحة الحديثة، 1981، 1981، مج1، ص91. } 91
\end{aligned}
$$




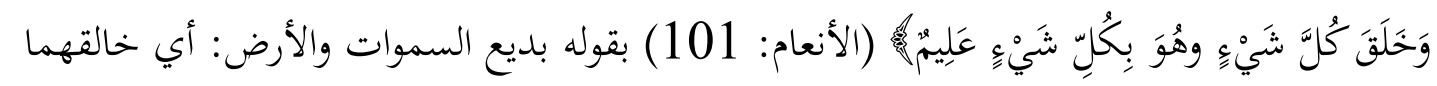
ومبدعهما على غير مثال سابق.

ويككن الاستنتاج، في ضوء ما ذكر : "أن الله سبحانه وتعالى هو: "بديع السموات والأرض"؛

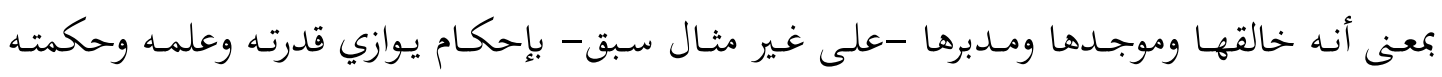

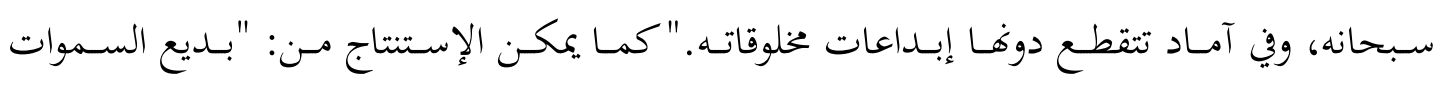

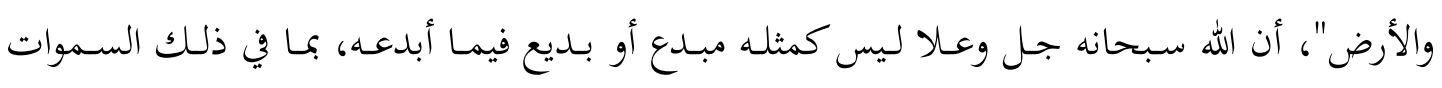

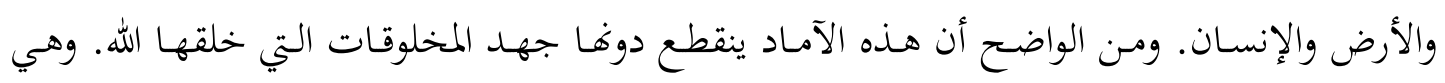

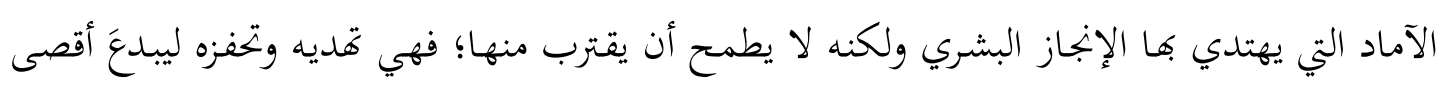

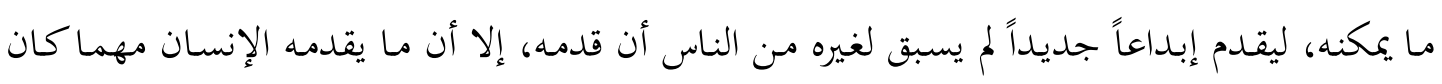

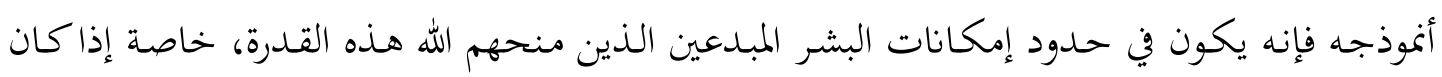

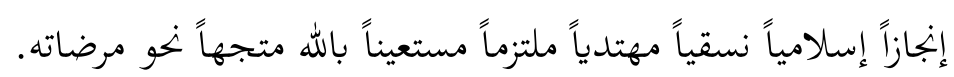

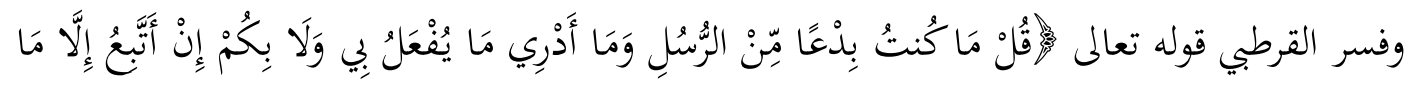

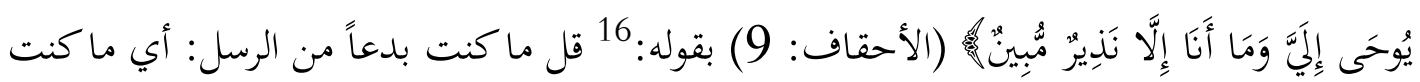

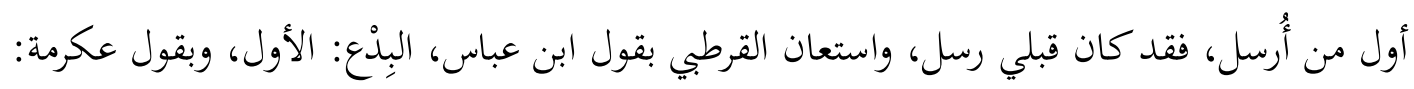
ما كنت صاحب بِدَع، كما أورد القرطبي. ويمكن الاستنتاج أن الإبداع هو الأداء المتميز على غير مثال سابق في تميزه وإن تكررت

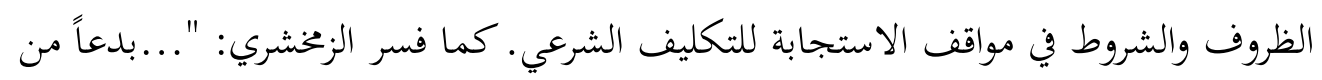

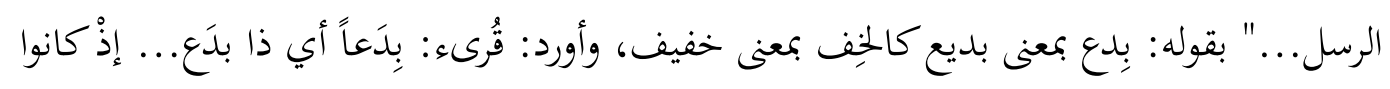

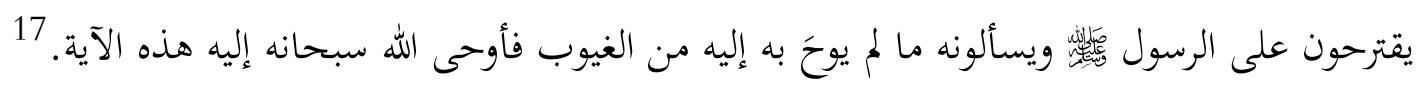

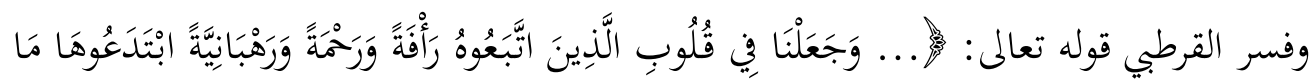

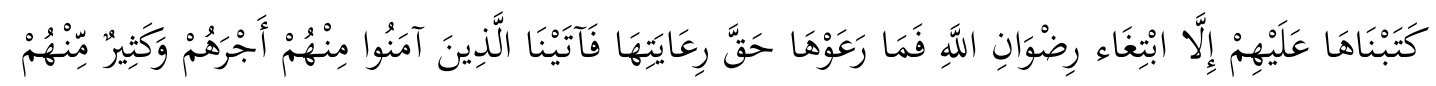

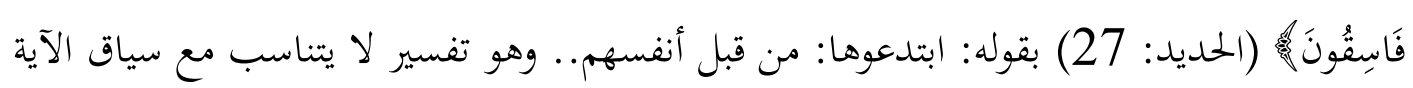

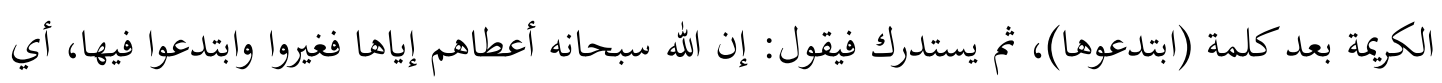

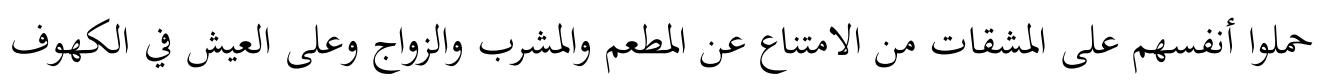


والصوامع."18 ويمكن الاستدراك على قول القرطبي بأن الله سبحانه وتعالى لم يكلفهم هذه المبالغة في

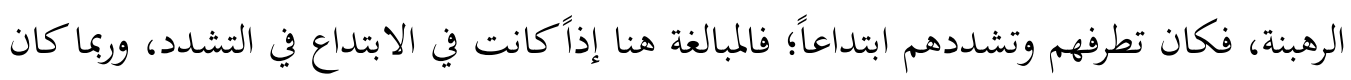

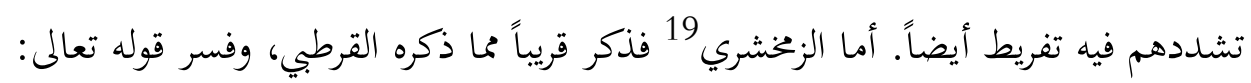

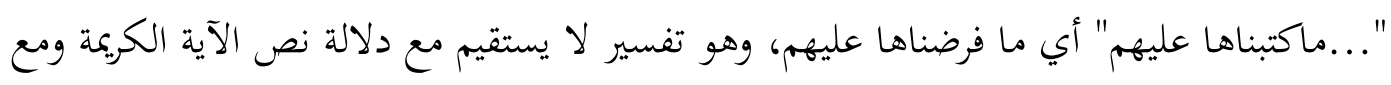

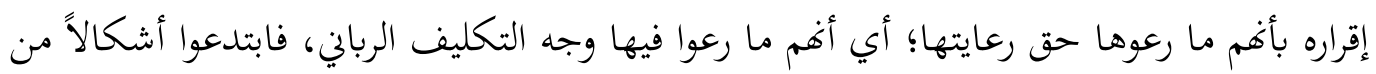
الترهب والإفراط والتفريط لم تكن واردةً في التكليف الذي تثبته الآية ولا تنفيه.

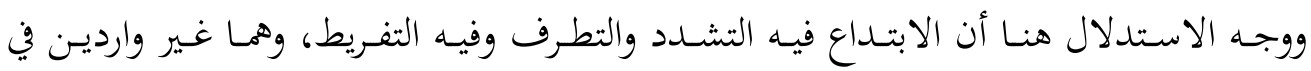

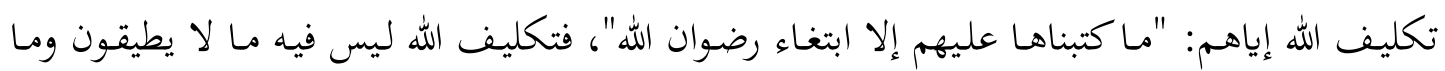

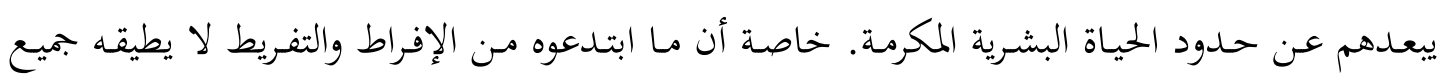

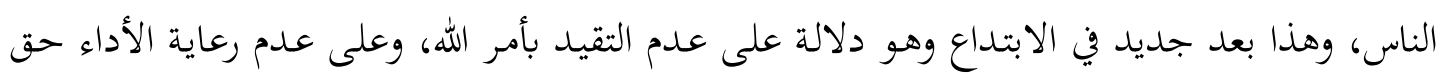

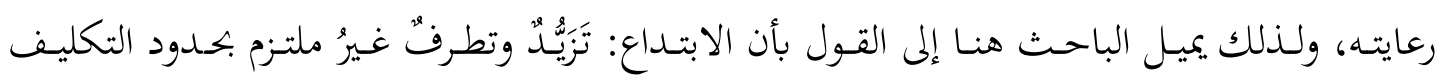

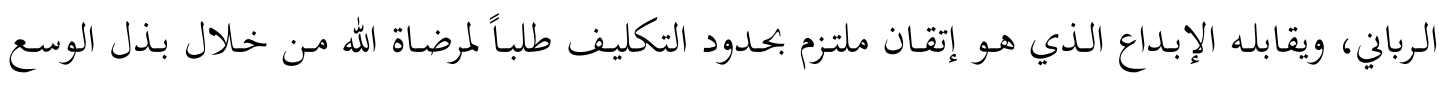
وأقصى الجهد الذي يستطيعه المخاطب المكَلَّنُ .

\section{2. مفهوم الإبداع في دلالات السنة النبوية:}

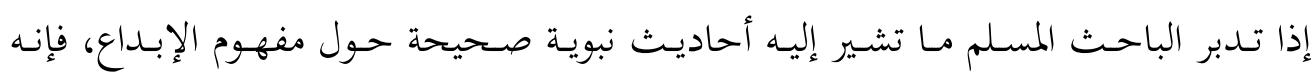

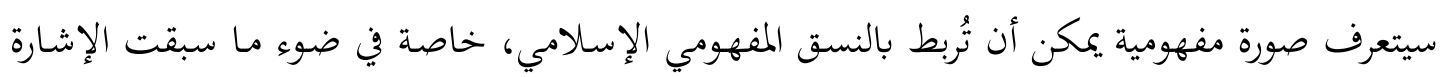

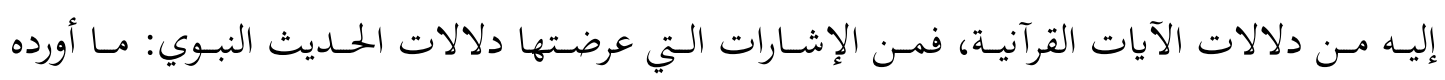

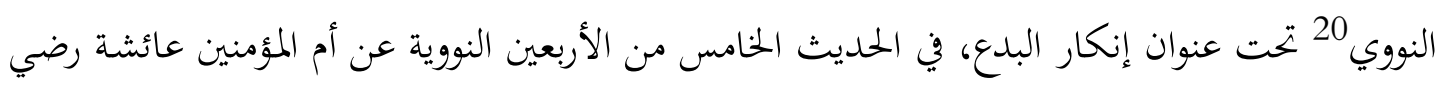

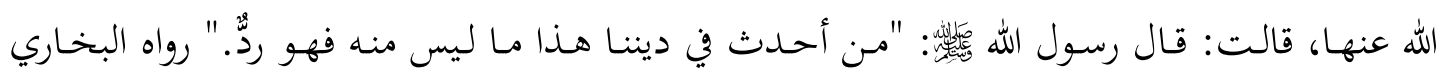

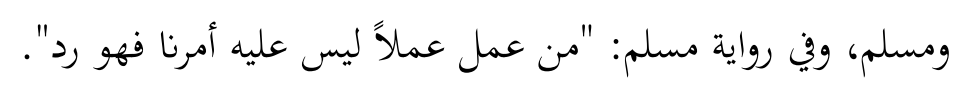

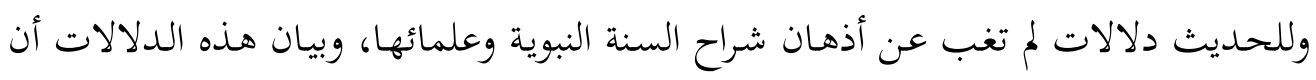

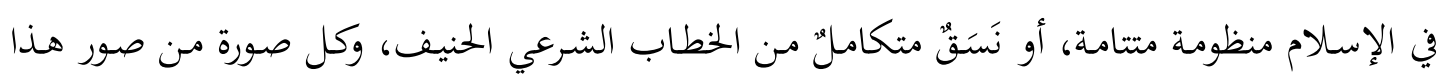

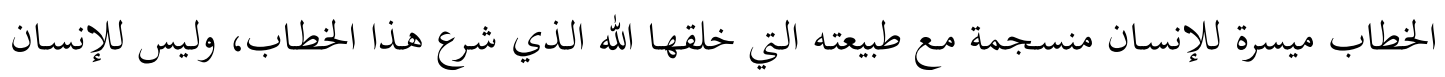

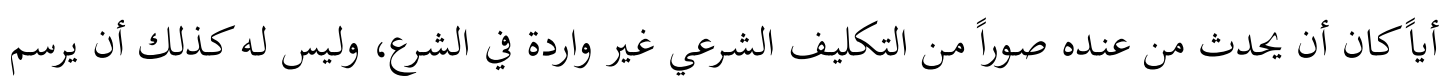

$$
\begin{aligned}
& \text { (18) القرطبي. الجامع لأحكم القرآن، مرجع سابق، مج16، ص155. 155. }
\end{aligned}
$$

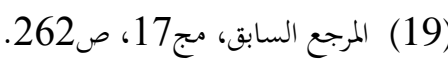

$$
\begin{aligned}
& 20 \text { مسعود. المختار من شح الأربعين النووية، مرجع سابق، ص35. }
\end{aligned}
$$


صورة الأداء مـن عنده، ولكـن درجـات الالتزام، والطاعـة والولاء للإسلام، وابتغاء وجـه الله ومرضاته

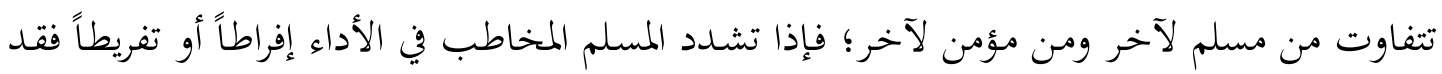

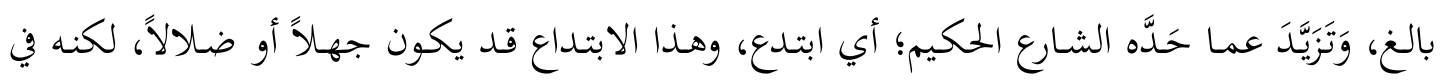

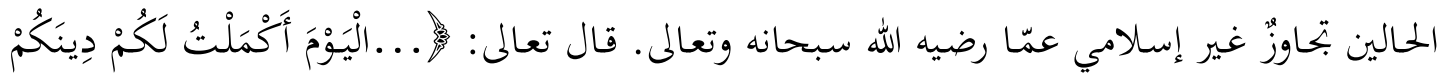

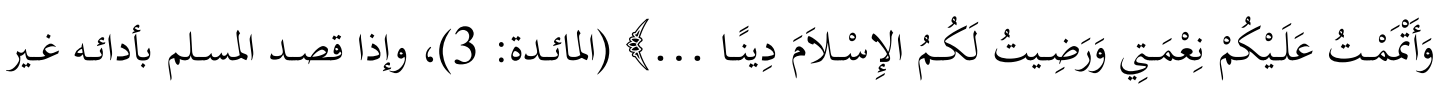
مرضاة الله سبحانه وتعالى -والعياذ به- أو أداه، أو دعا إليه بصورة تشوبها الشوائب فهو مردودُ عليه؛

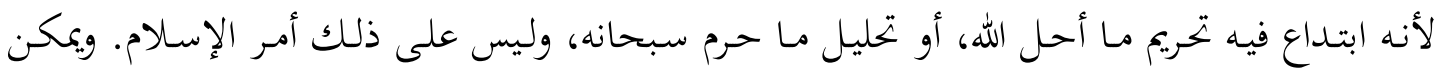
القول بأنه نوع من الإبداع الضال أو البدعة السيئة.

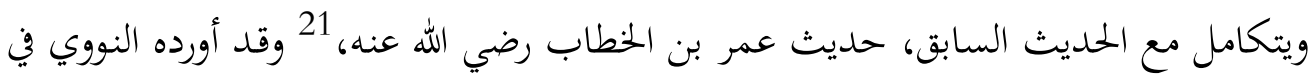

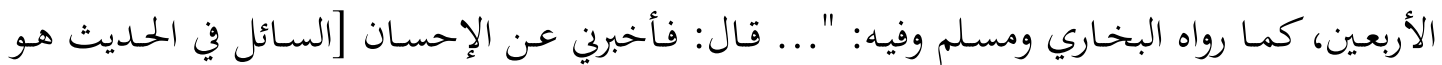

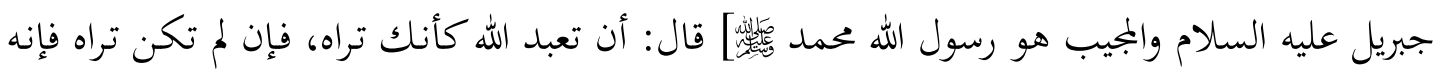

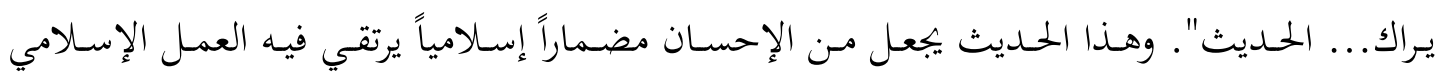

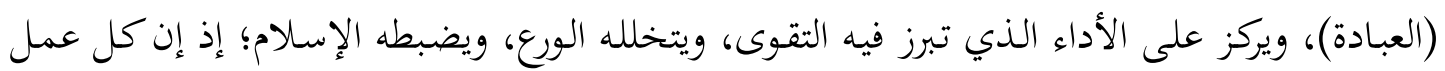

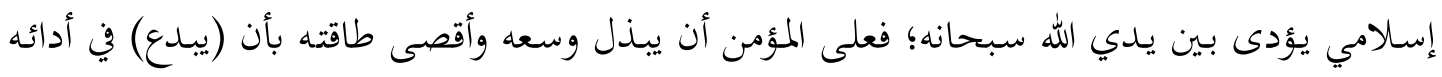

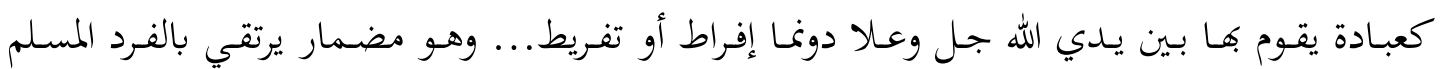

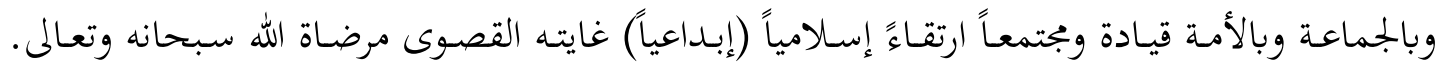

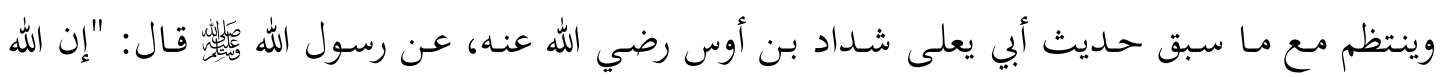

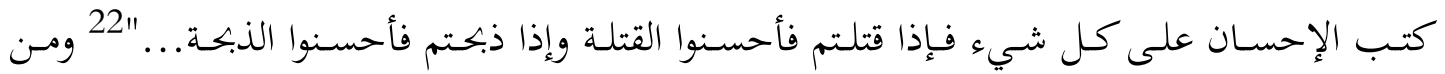

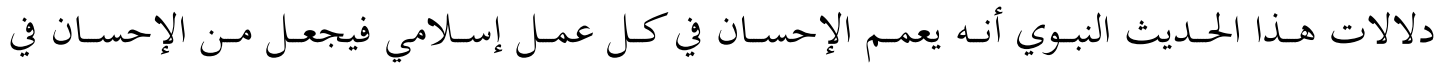

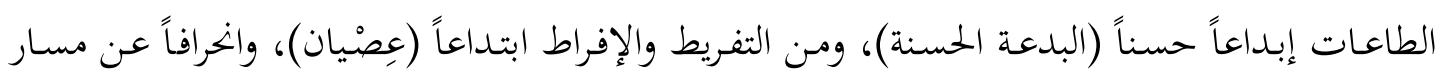
الإحسان، وتحاوزاً لوسطية الإسلام.

ثم إن السنة النبوية المطهرة تقيم الحجة البالغة، في أمر الإبداع والبدعة؛ ففي حديث أبعام أبي الدرداء

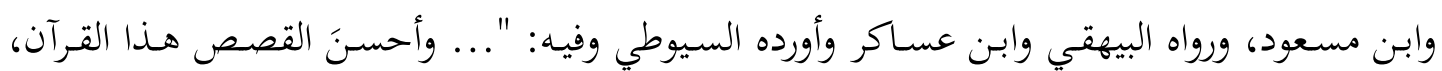

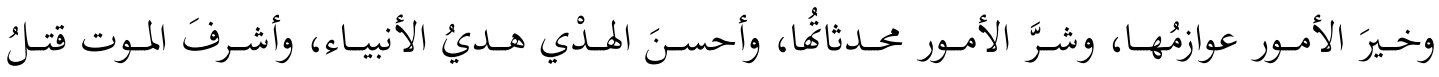




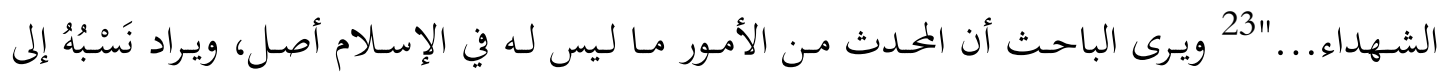

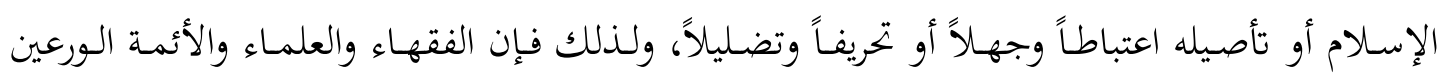

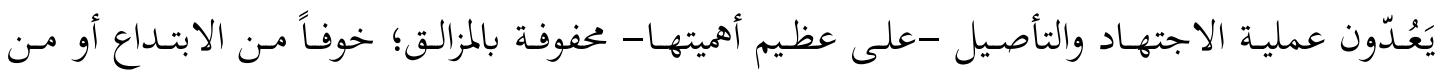

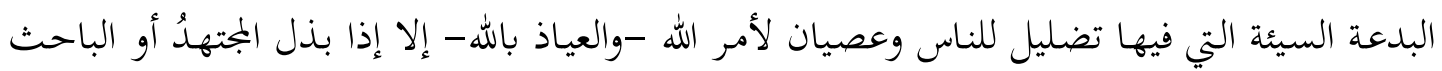

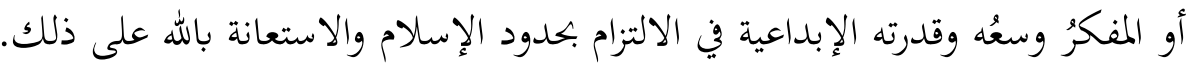

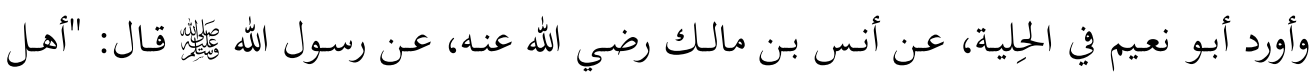

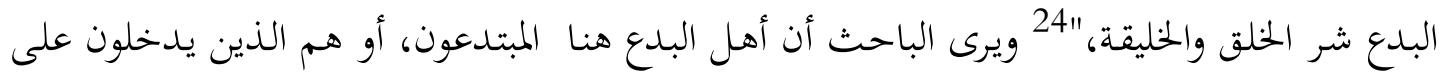

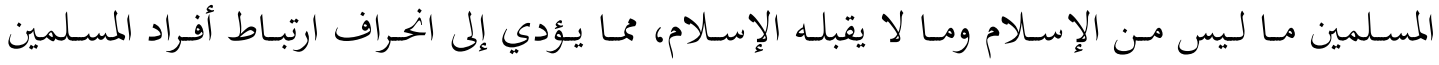

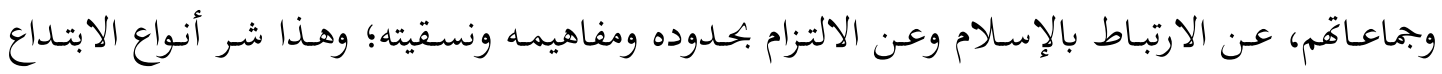

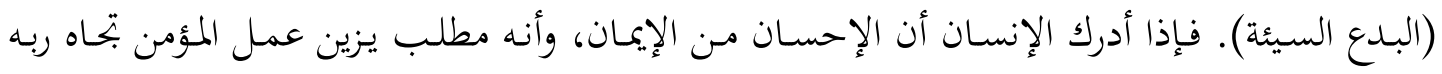

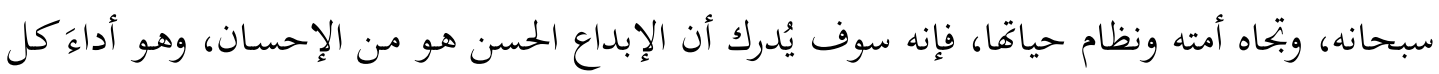

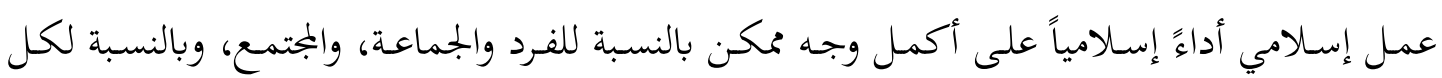

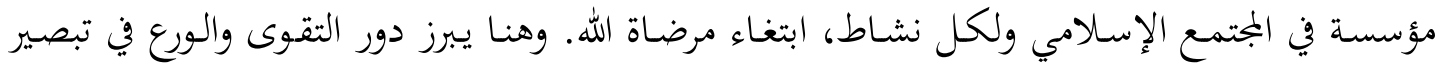
الناس ببذل أقصى ما يسعهم في طاعة الله ، وفي تيسير ذلك عليهم.

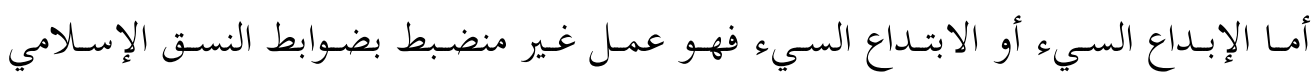

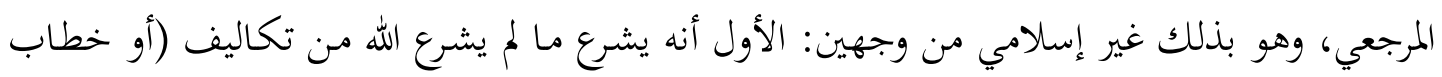

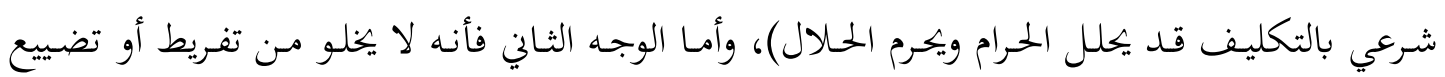

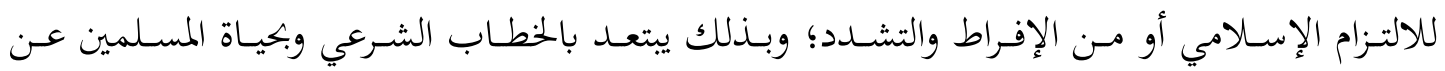

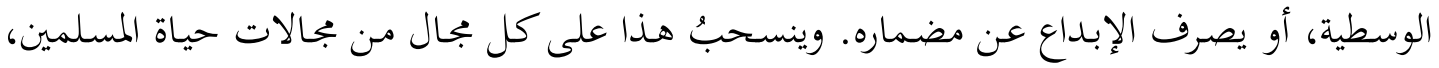

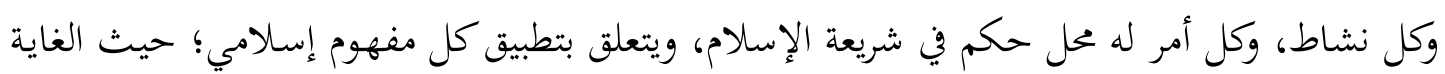

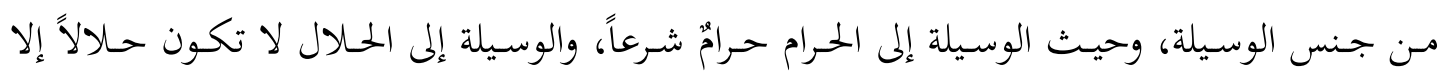

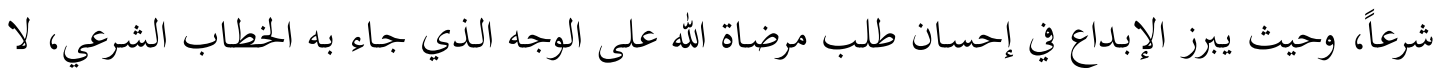
على الوجه الذي يبتدعه المبتدعون الضالون المضلون، منفلتاً من ضوابطه المرجعية الإسلامية.

3. مفهوم الإبداع في المرجعيات اللغوية العربية:

23 السيوطي، جلال الدين أبي بكر. الجامع الصغير في أحاديث البشير النذير، بيروت: دار الكتب العلمية، ج1، ص64.

24 المرجع السابق، ج1، صلال ل109 المبر. 
ورد في مختار الصحاح: أبدع الشيء: اخترعه لا على مثال، والبديع: المبتدع، والبديع: الزق -

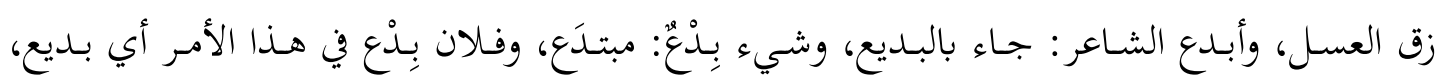

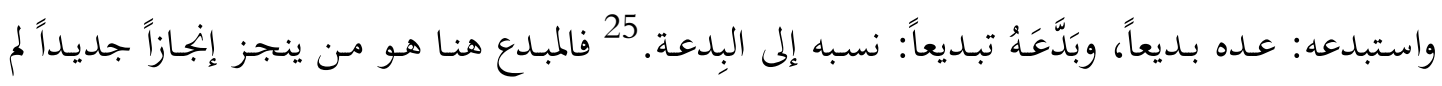
يكن له مثيلٌ سابق.

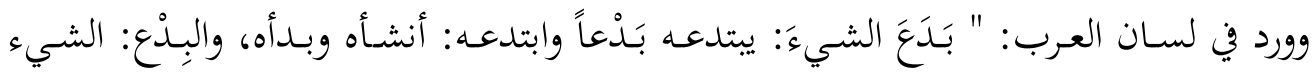

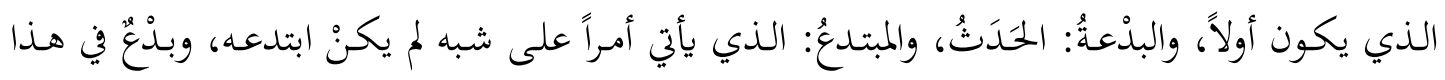

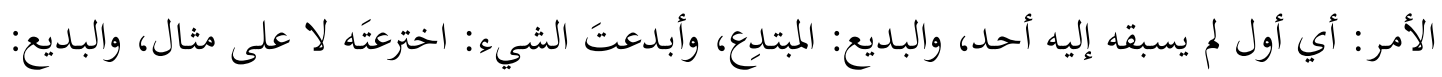

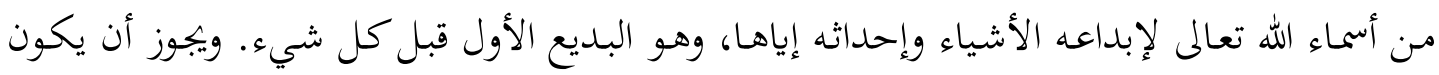

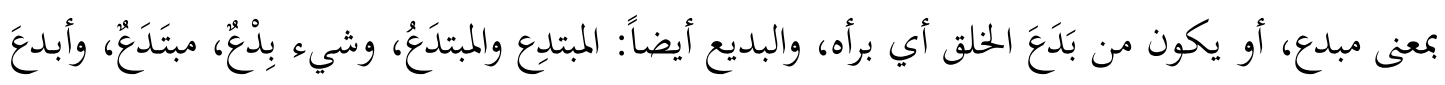

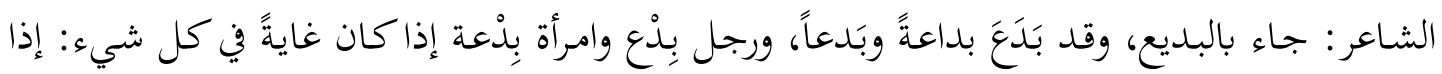

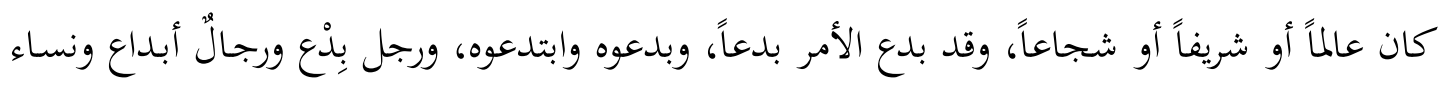

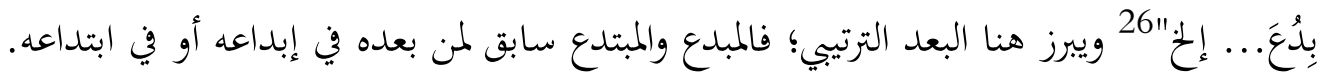

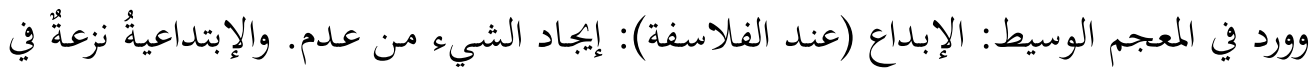

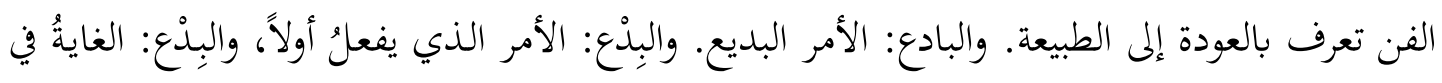

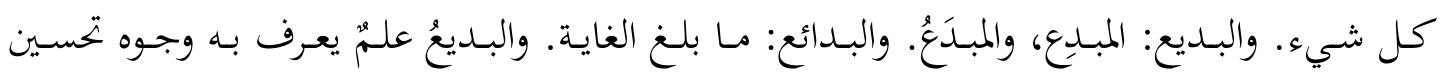

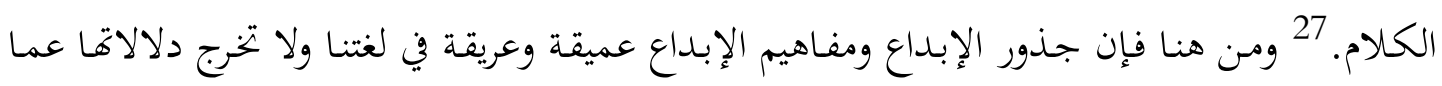

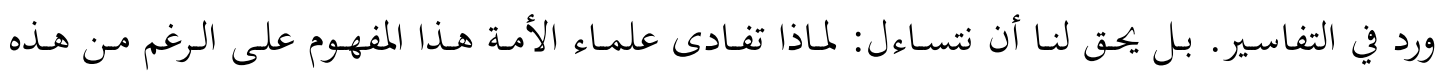

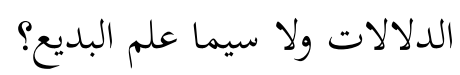

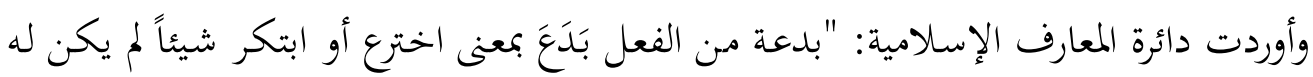

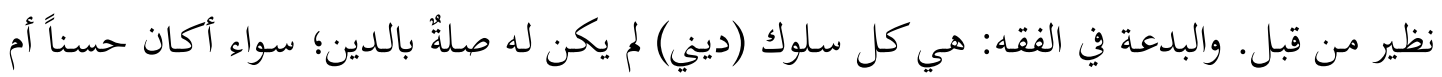

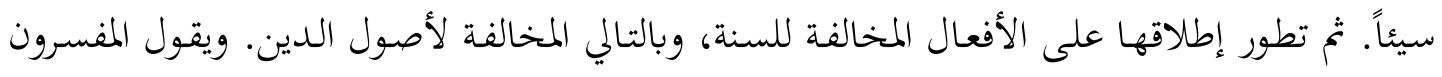

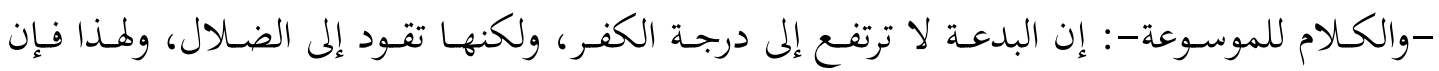

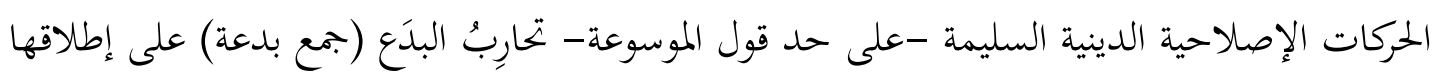

25 الرازي، محمد بن أبي بكر بن عبد القادر. مختار الصحاح، القاهرة: دار هضة مصر، د. ت، ص43.

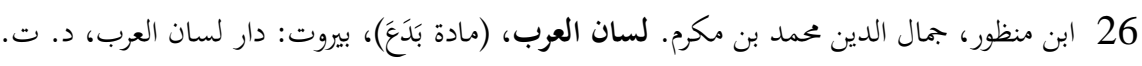

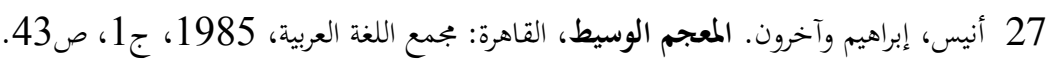


و بأي شكل من الأشكال."28 ولئن نقلت دائرة المعارف هذا الحديث إلى أداء الحركات (الإصلاحية

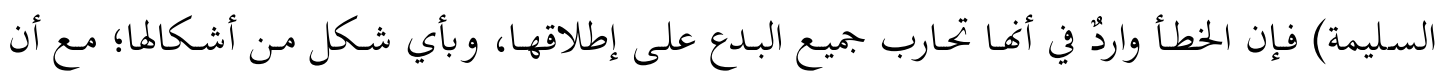

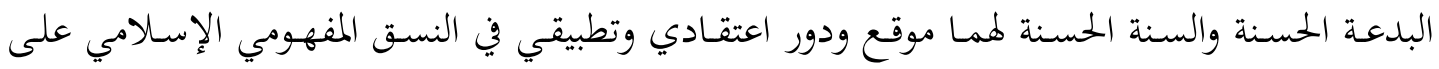
سلم الإحسان في الأداء طلباً لمرضاة الله سبحانه وتعالى.

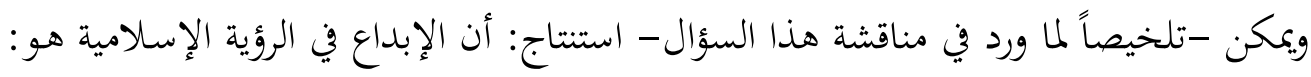

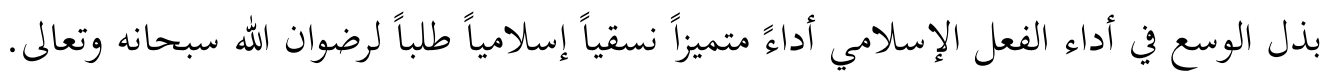

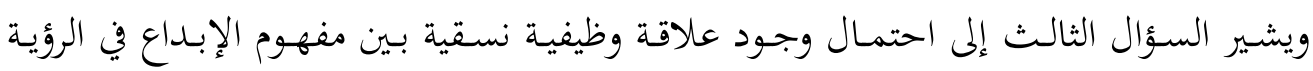

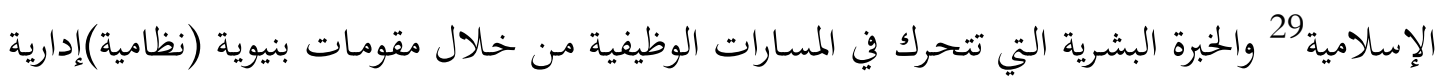

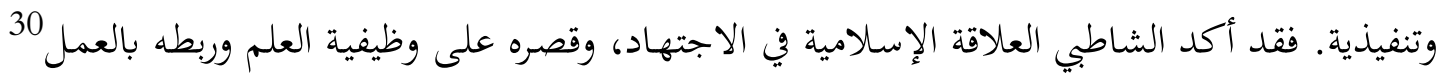

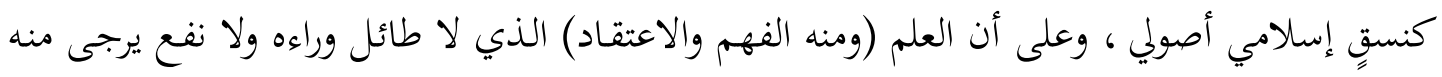

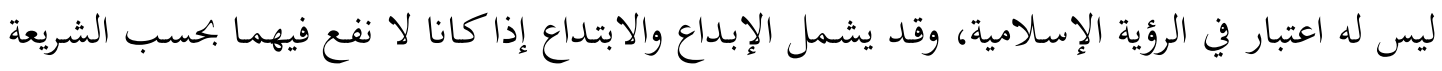

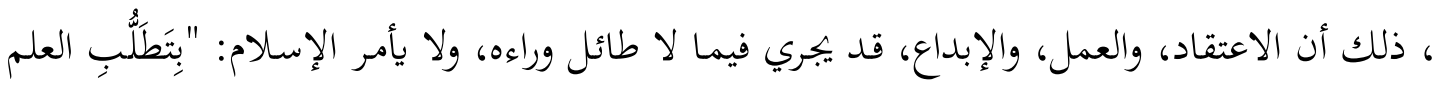

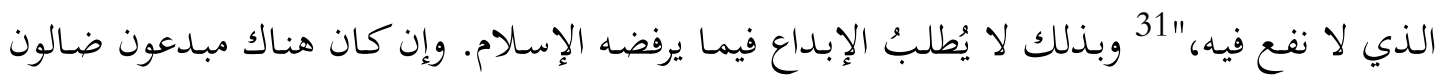
ومُضلُُّنَ.

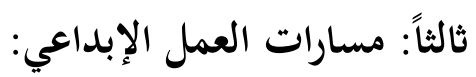
يفترض في الأمة الإسلامية أن توظف الإبداع في كل نشاط إسلامي من خلال المبدعين في كل جيل، وفي حدود النسق الإسلامي ، ليقوم هؤلاء بإبداعاقم في أداء الإسلام تطبيقاً وإحساناً ومملاً

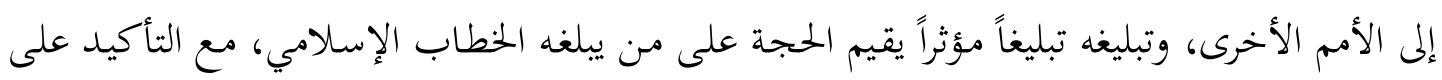

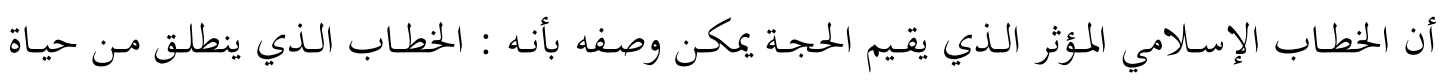

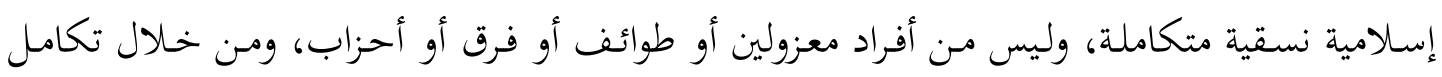

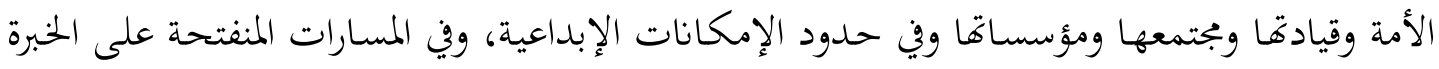

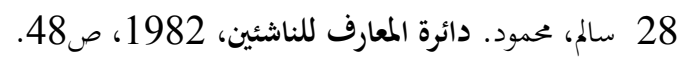

29 الشاطبي، أبو إسحاق إبراهيم بن موسى. الموافقات في أصول الشريعة، بيروت: مؤسسة الرسالة، 1999، ج1، ص2 
البشرية المتجددة في مجالات تنظيم المعرفة وإدارقا، ولكن في نطاق ضوابط النسقية الإسلامية وتفعيلها

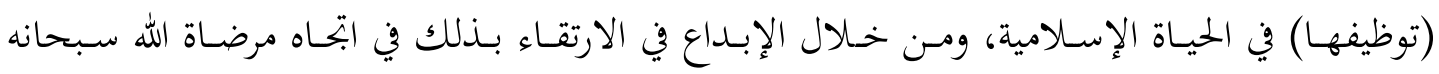

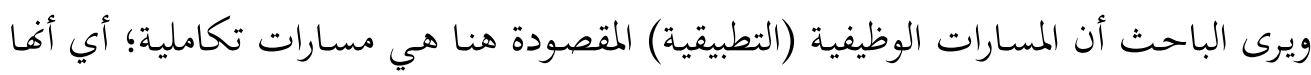

تتكامل فيها إبداعات الأمة أفراداً ومؤسسات. ويمكن الإشارة إليها بإيماز فيما يأتي:

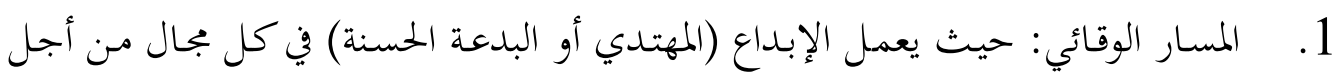

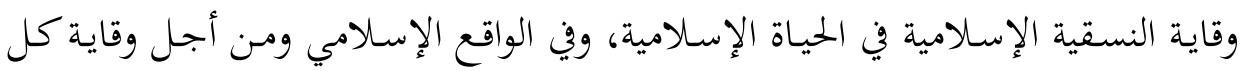
فهم وكل عمل وكل شعور إسلامي من الشوائب التي يمكن أن تشوبه نظراً وأداءً وإنجازاً.

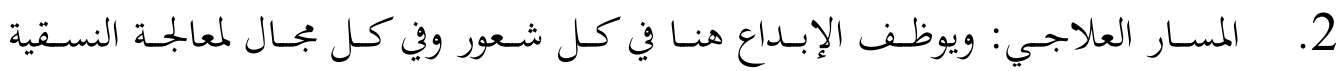

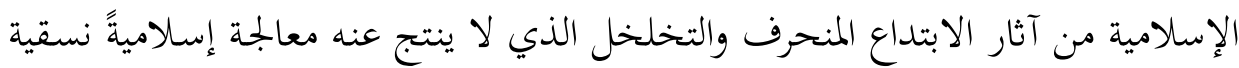

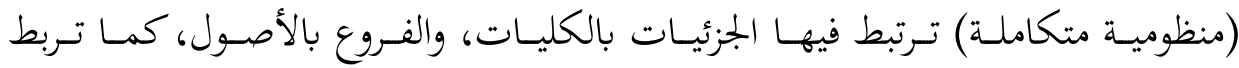

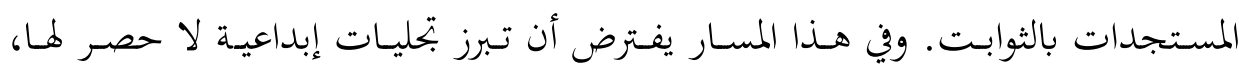
تنتمي إلى النسقية الإسلامية، ابتغاء مرضاة الله في كل نمط من هذه الإبداعات المهتدية.

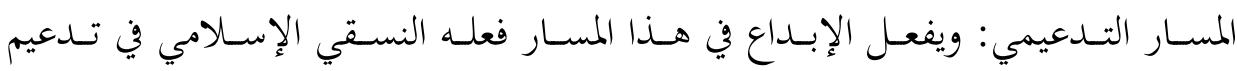
.3

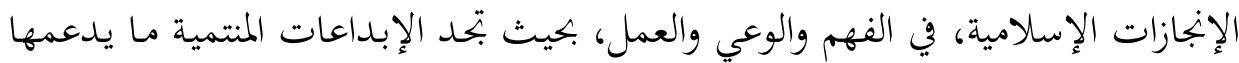

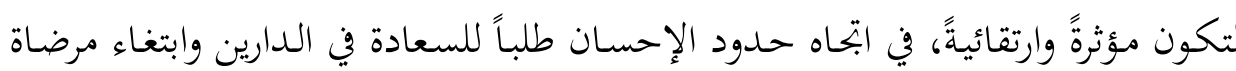
الله.

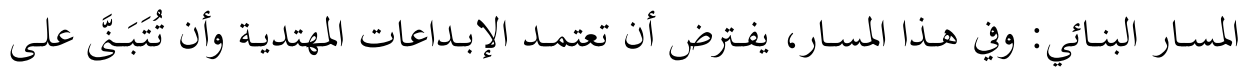

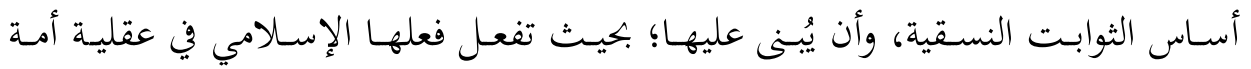

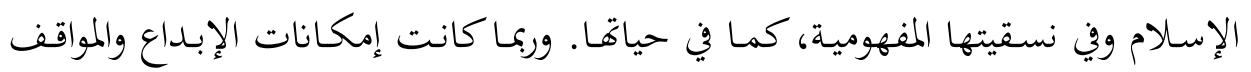

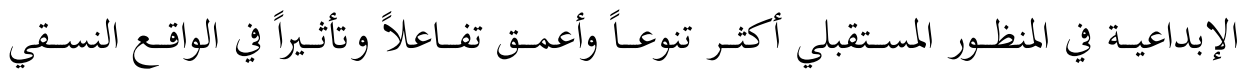

$$
\text { الإسلامي، من أن تحصر. }
$$

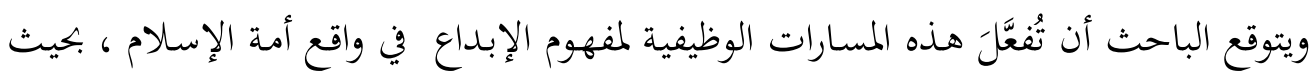

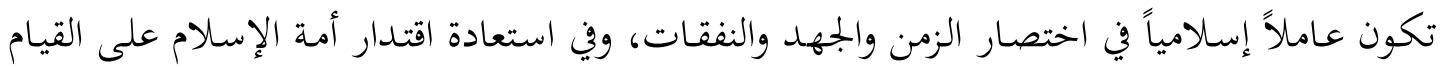
بدورها الحضاري المهتدي في مخاطبة الأمم وقيادتما. 


\section{رابعاً: المقومات التنظيمية لتفعيل مفهوم الإبداع في الواقع الإسلامي:}

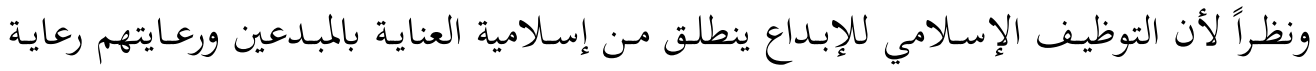

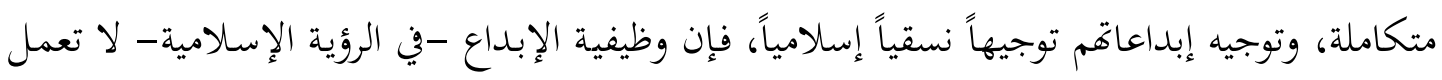

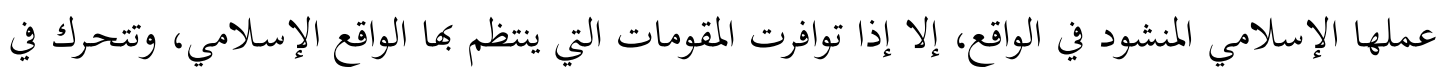

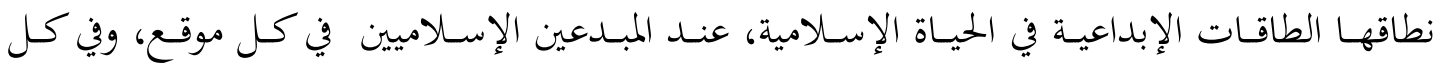

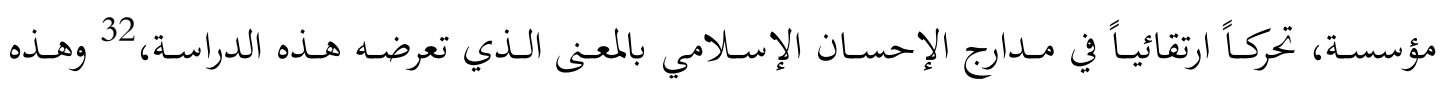

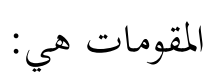

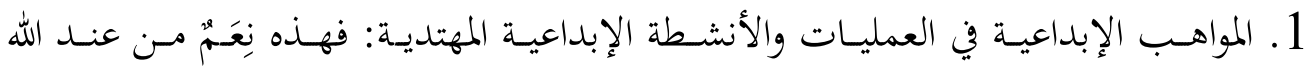

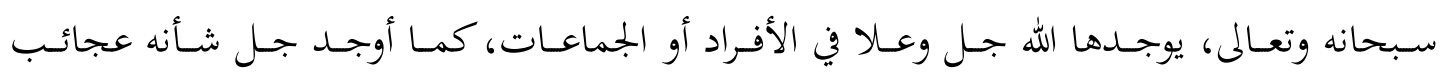

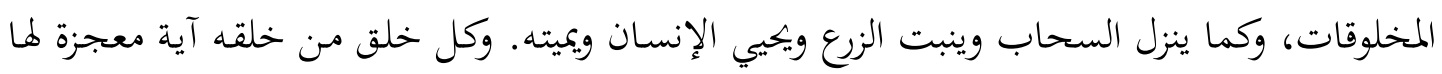

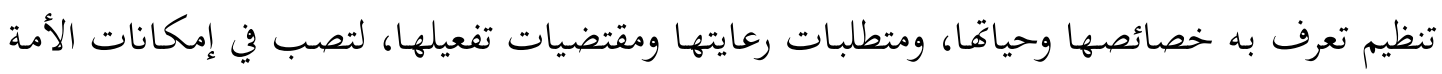

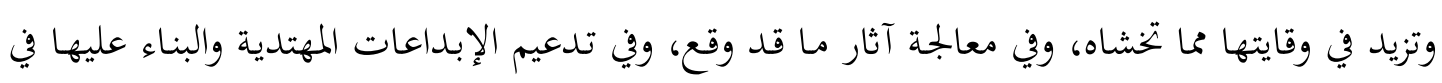

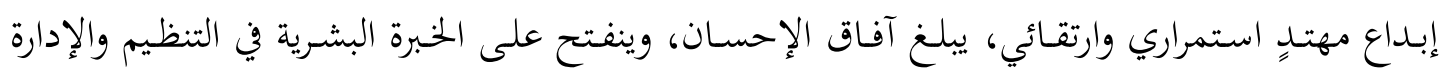
الإبداعيين.

ويقتضي هذا النظر إلى الإبداع الإسلامي على أنه نظام أو عملية نظامية عند أفراد الأمة،

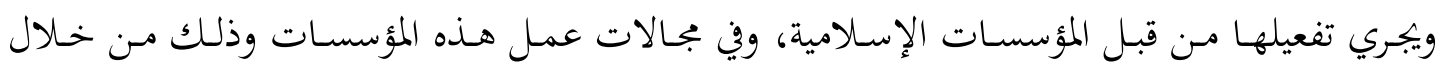

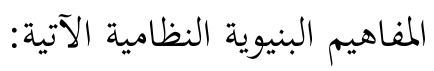
2. مدخلات العملية الإبداعية:33 وهي لفظة محدثة، وتعني خصائص النظام (نظام الإبداع)

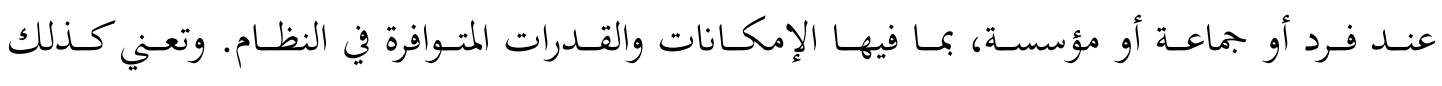

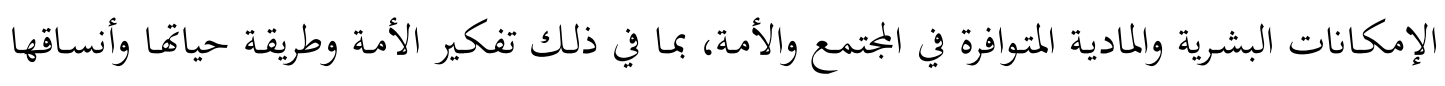

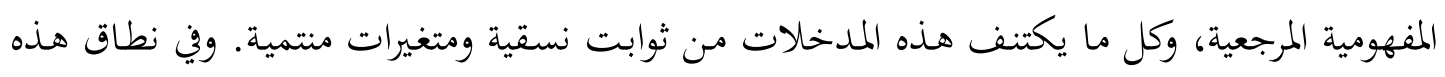

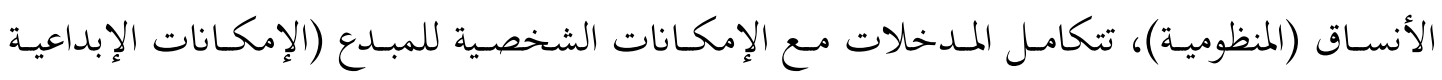
الشخصية) التي تستثيرها المخرضات النسقية الإسلامية، وتبرز في المسارات الواقعية التئ سبق التهات ذكرها.

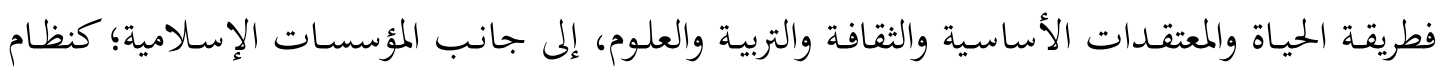

32 الإحسان بذل أقصى الوسع في الإنجاز على أساس أنه عبادة تُبتغى فيها مرضاة الله سبحانه وتعالى وليس الإبداع في ذاته،

$$
\text { انظر مرجع 42، صفحة } 25 .
$$

33 Halsey, William, D., 1982, Merit Student Encyclopedia Dictionary, New York, 1979, p. 531. 
الأسرة، والمدرسة، والمسجد، والجامعة، وغيرها من الأنساق المؤسسية الإسلامية، التي تتكامل في تفعيل

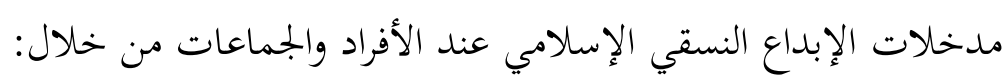

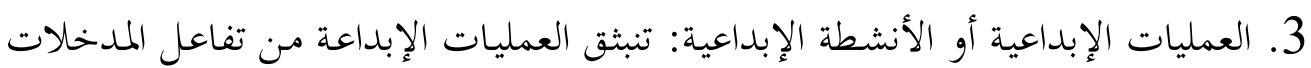

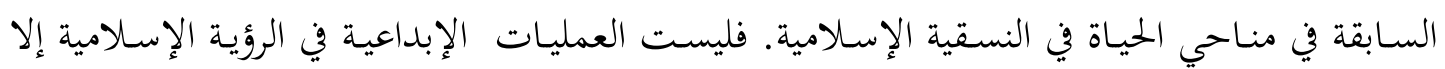

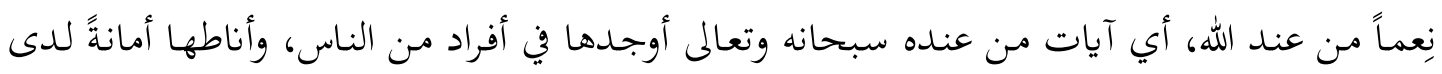

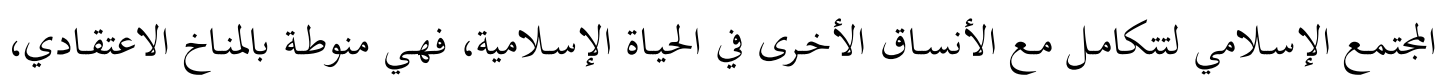

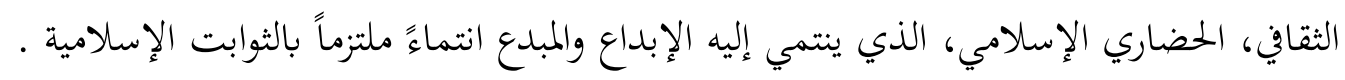

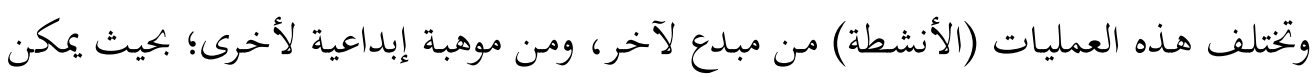

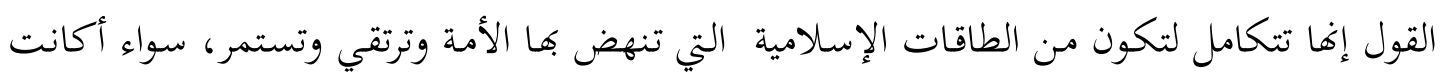
هذه العمليات داخلية -أي داخل السياق الحضاري- أم خارجية.

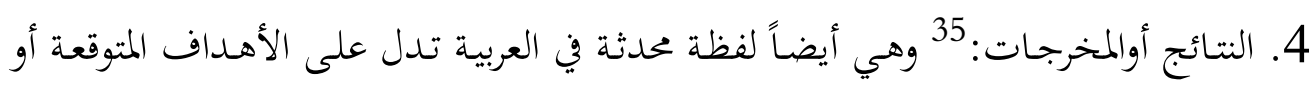

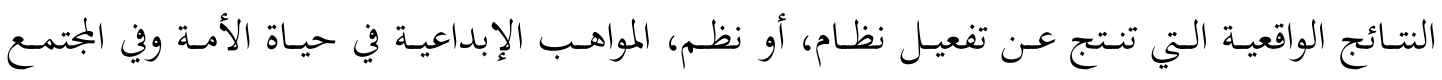

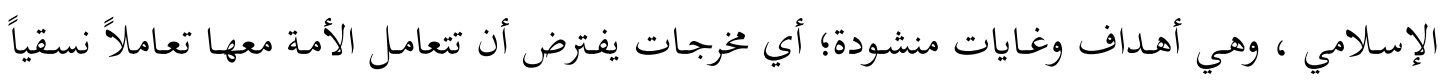

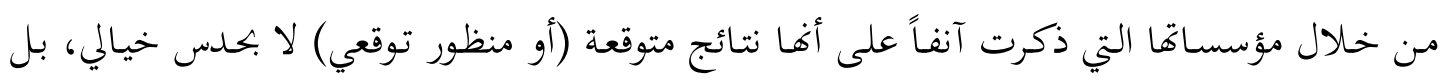

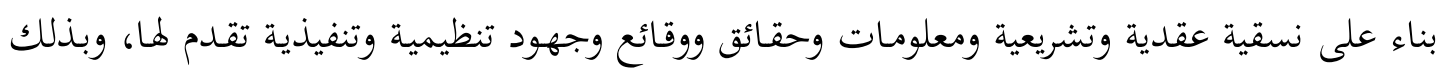

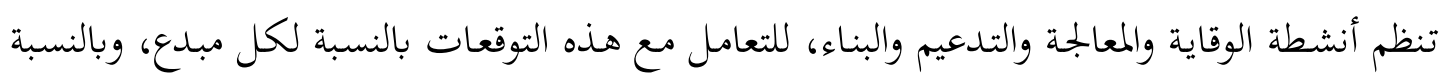

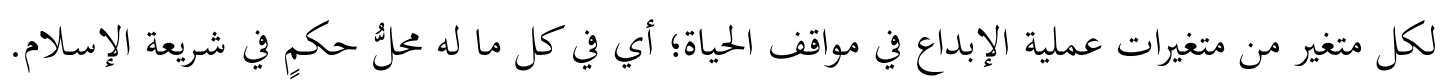
أو أهــاف واقعيـة تظهـر في الواقع وفي النشـاط اليـومي للمؤسســات، كإبـداعات عقليـة، أو نتـائج

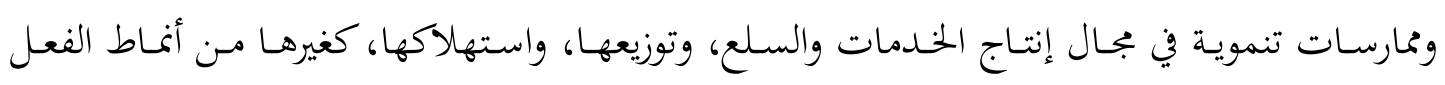

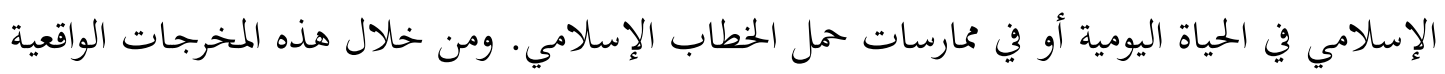

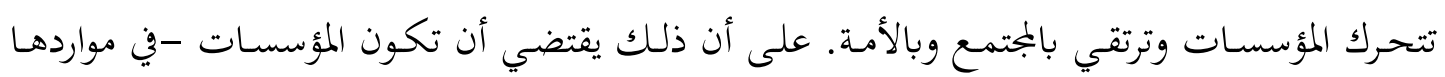

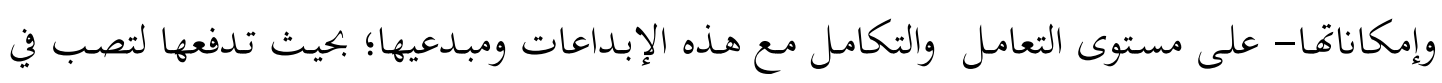
كيان الأمة، فترتقي بها في ابتحاه مرضاة الله سبحانه وتعالى.

$$
\begin{aligned}
& 34 \text { انظر فقرة } 1 \text { القسم الأول من البحث صفحة. }
\end{aligned}
$$

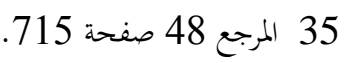




\section{خامساً: متطلبات الواقع الحضاري: - (لمات}

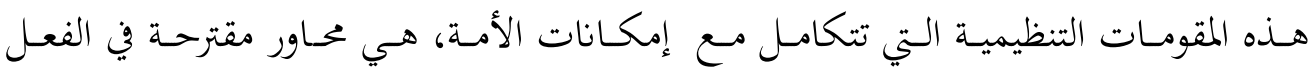

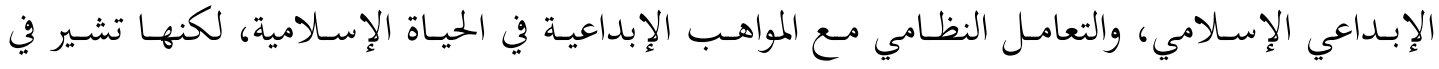

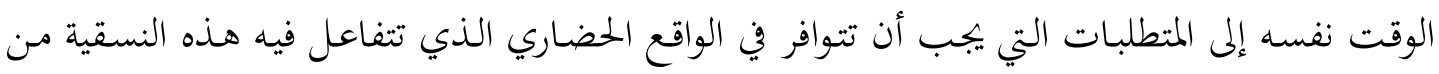

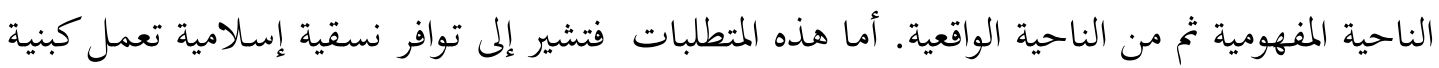
مفهومية أساسية، Conceptual Infra Structure تسبق توظيف مفهوم الإبداع في أبعاده

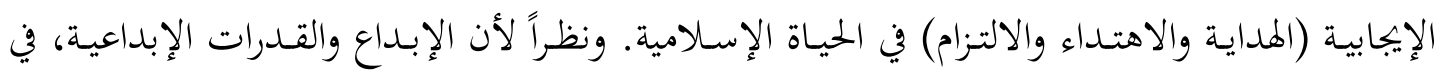

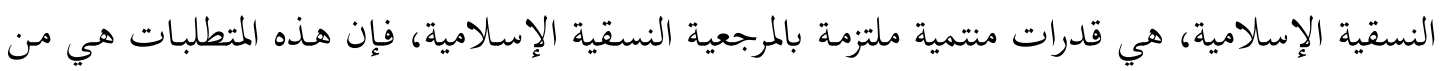

$$
\text { الخصوصيات الحضارية36 للمجتمع الإسلامي أي من الثوابت المفهومية الإسلامية. }
$$

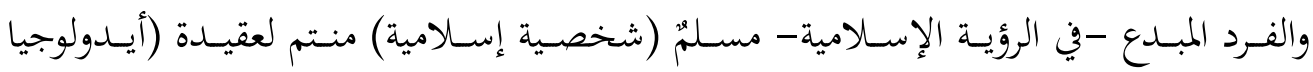

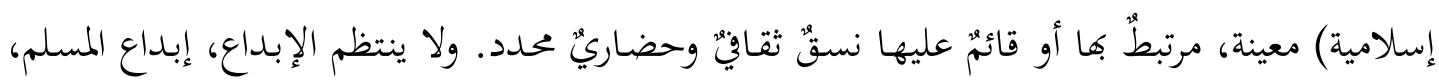

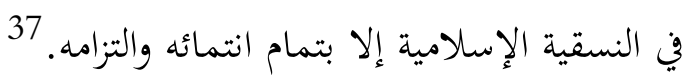

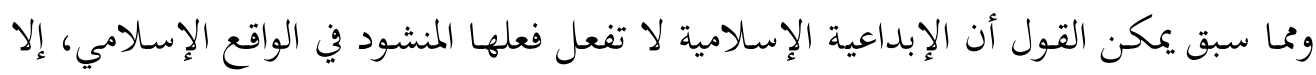
إذا توافرت المتطلبات النسقية القبلية الآتية: 1. المتطلبات الاعتقادية (الأيديولوجية):38 وهي في النسقية الإسلامية منظومة من القناعات

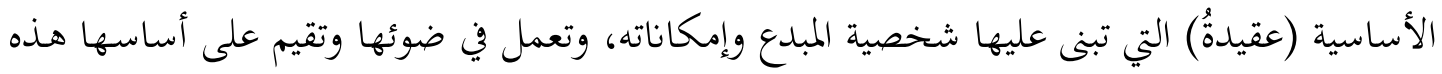

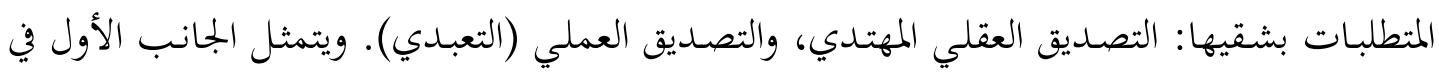

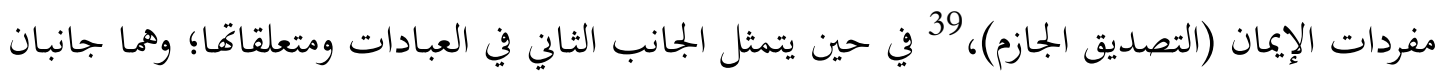

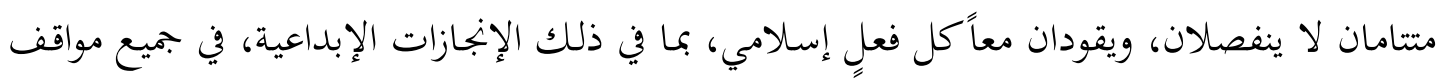

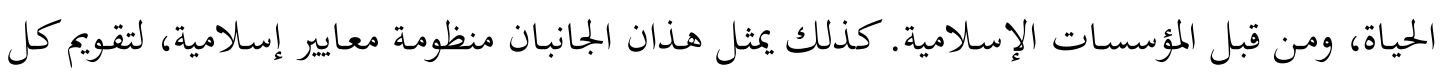

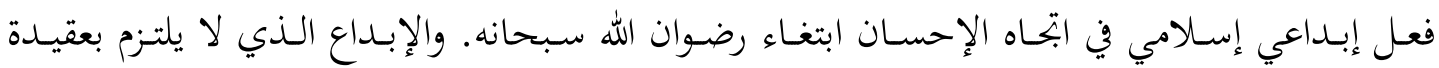

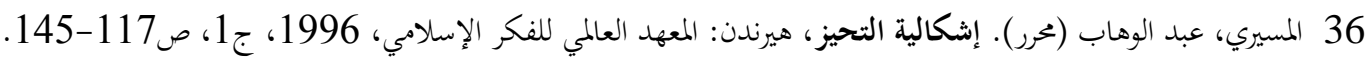
37 يرى الباحث أن الإبداع يصبح دون الالتزام والانتماء بتحارة شخصية ويفقد إبداعيته كما يفقد إسلاميته.

38 Bulloclx, allan, Ctal, The Fontana Dictionary of Modern Thought, $2^{\text {nd }}$ Edition, The Foutour Press, 1988, p. 404-405.

39 رمزي، عبد القادر. "الجامعة في الوطن العربي: الأيديولوجيا، البحث العلمي، التنمية"، البجلة الأردنية للعلوم التطبيقية، ج3،

$$
\text { ع4 (أيلول 2000). }
$$




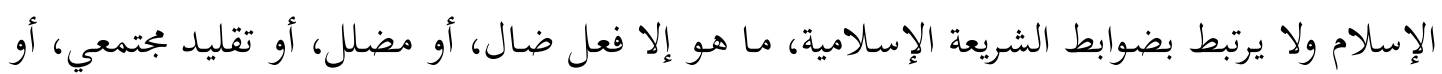
طائفي، أو حزبي، إنه إنجاز منقطع عن روابطه الاعتقادية (الأيديولوجية) في النسقية الإسلامية.

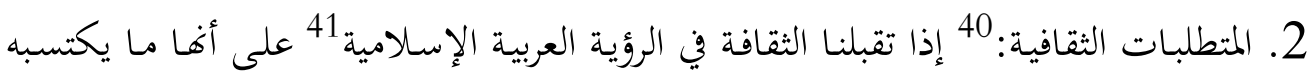

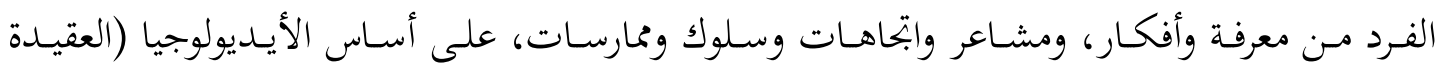

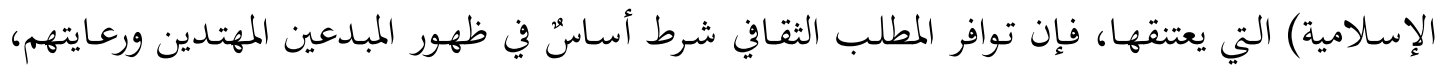

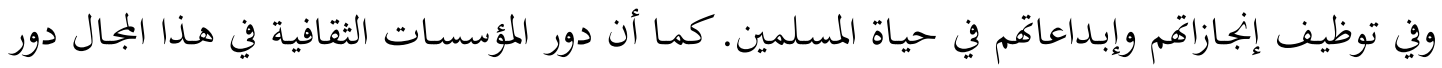

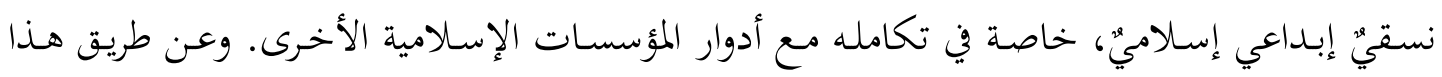

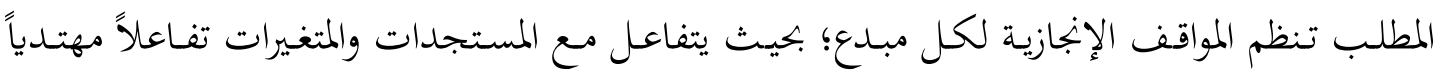

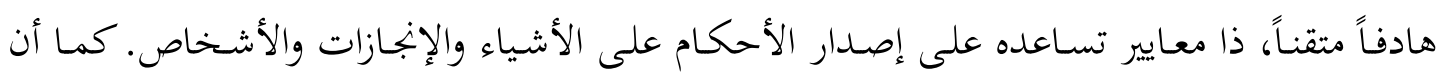

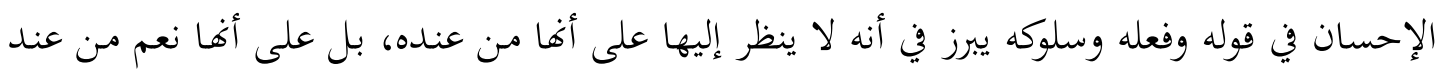
الله سبحانه وتعالى لها وظائف في حياته وفي حياة أمته، يؤجر عليها ويطلب بها رضوان الله.

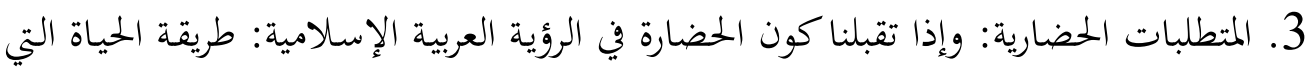

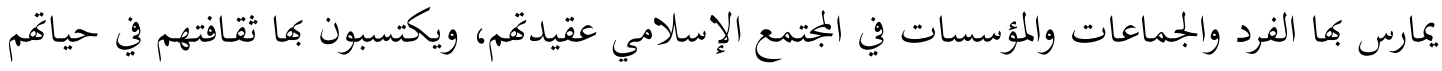

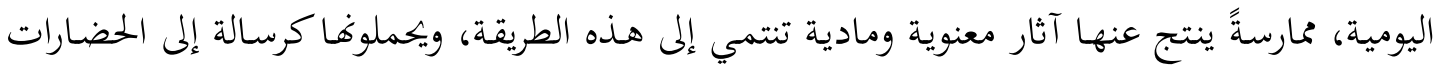

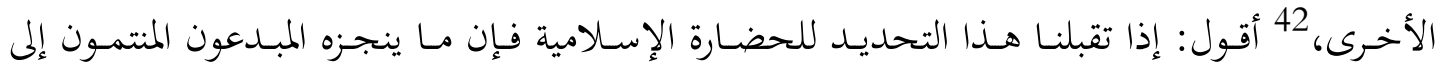

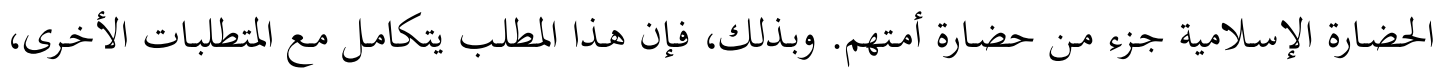

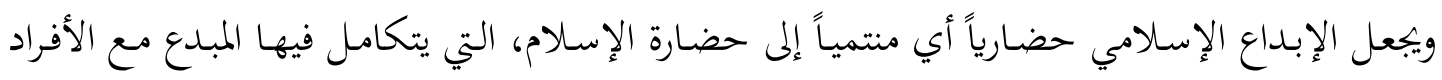

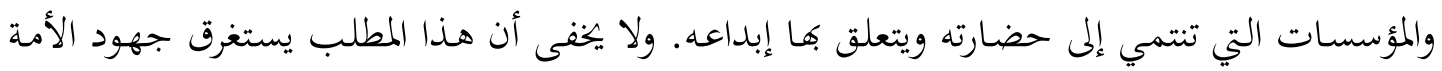

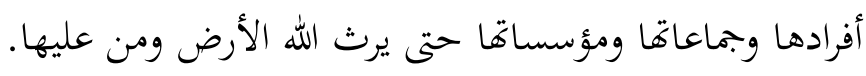

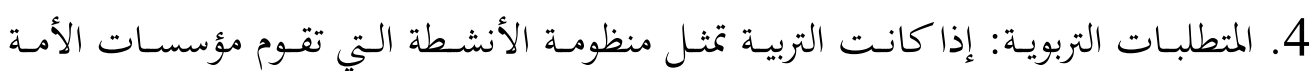

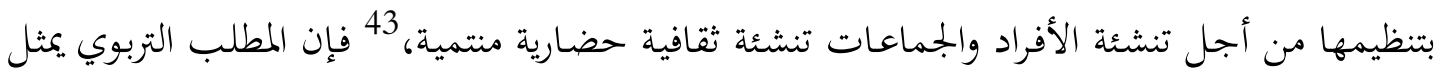

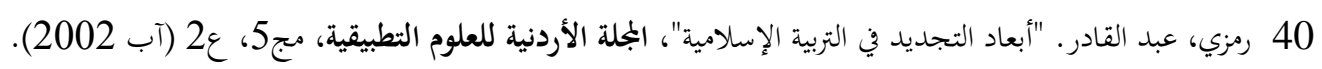

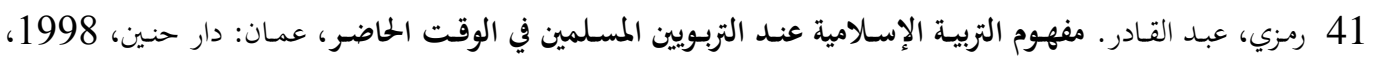
ص261. 42 السعيد، فؤاد. تحيزات غربية في فضنتا الحضارية، إشكالية التحيز، تريرير عبد الوهاب المسيري، هيرندن: المعهد العلمي للفكر

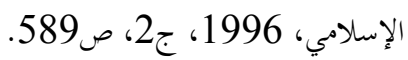
43 منتمية إلى ثقافة وحضارة انتماءُ نظرياً وتطبيقياً متكاملاً. 
موراً إسلامياً أساسياً في تربية المبدعين ورعايتهم وتأهيلهم للمشاركة في حياة مجتمعهم، وبذلك يبرز دور

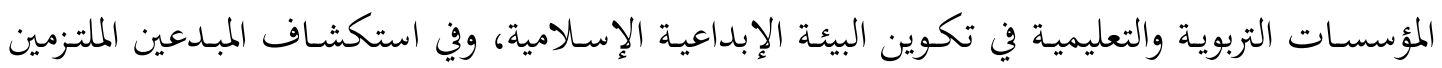

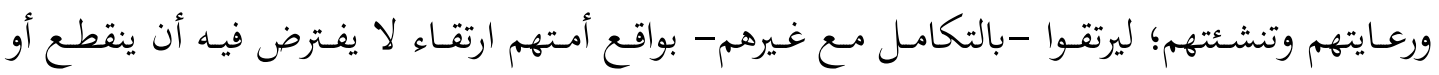

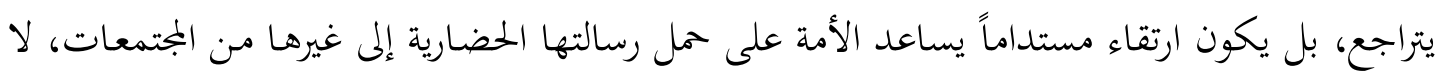

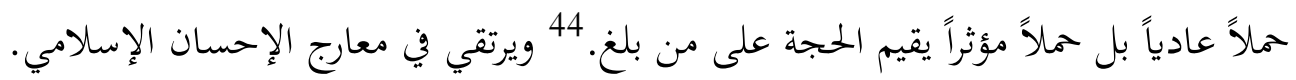

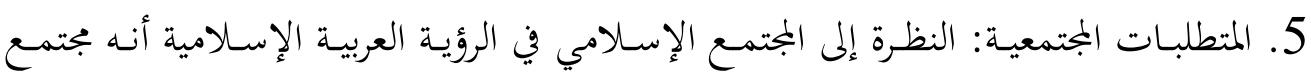

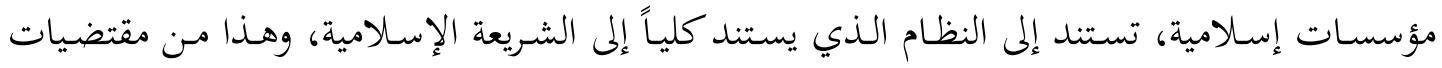

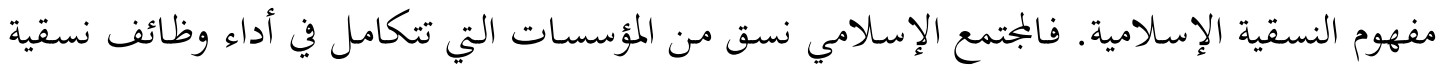

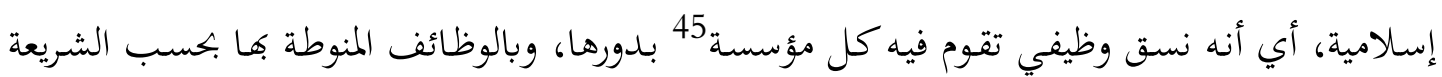

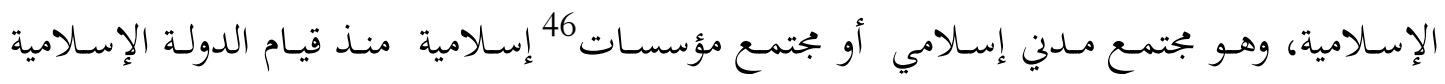

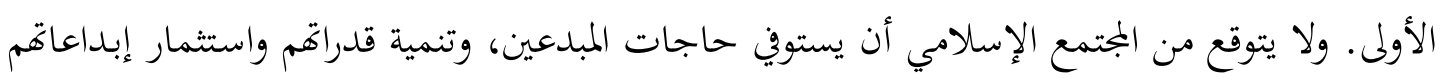

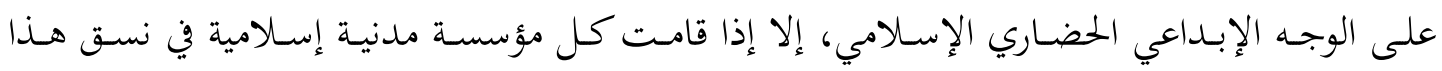

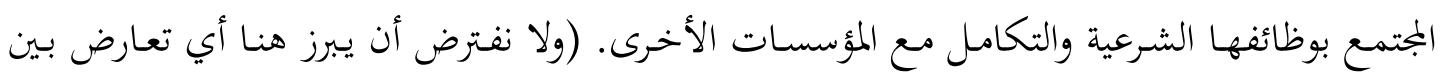

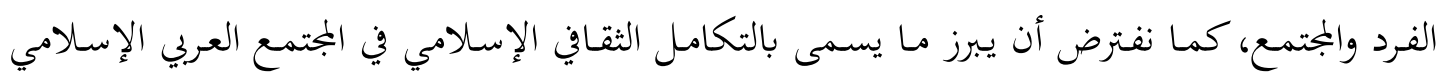
المرتقب). 47 وذلك من خلال تطبيق الشريعة الإسلامية في جميع جوانب الحياة.

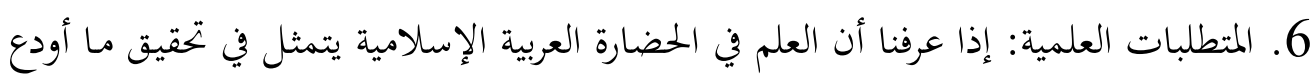

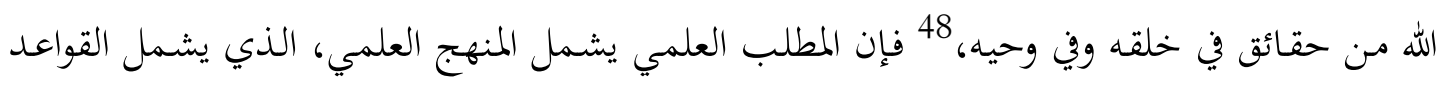

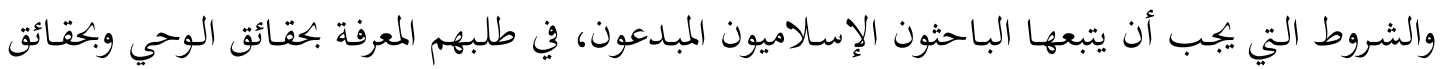

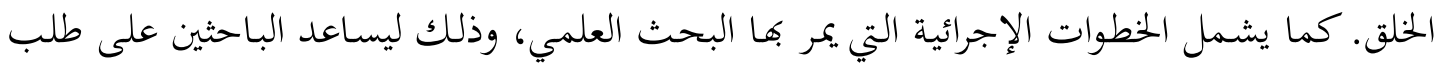

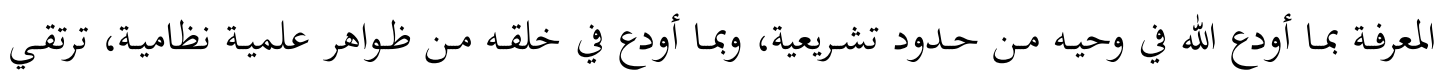

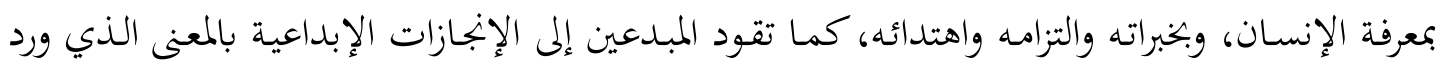

44 أي على كل من يتصل بالحضارة الإسلامية من خلال التربية الإسلامية.

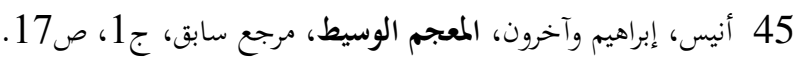

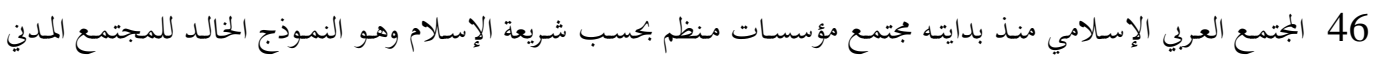


سابقاً. ثم إن تلبية هذا المطلب ومتعلقاته تقتضي توافر المراكز والإمكانات والتسهيلات على أعلى

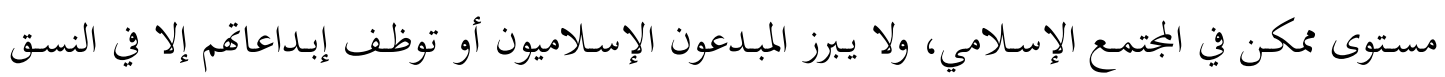

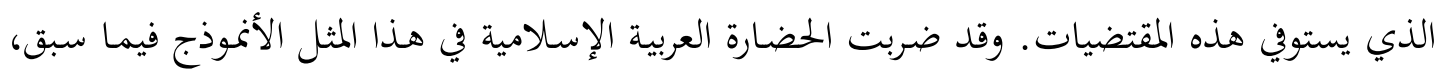

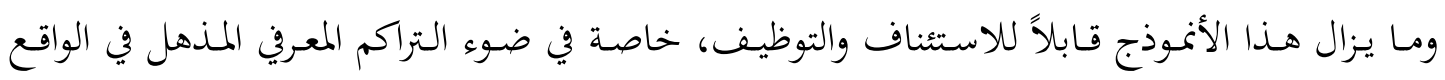

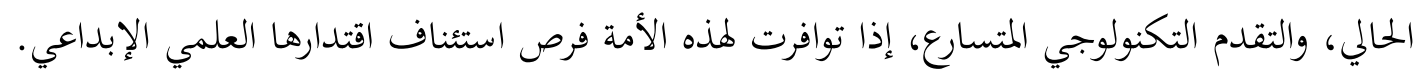

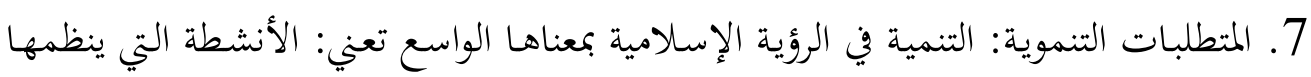

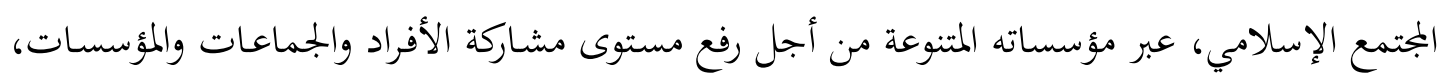

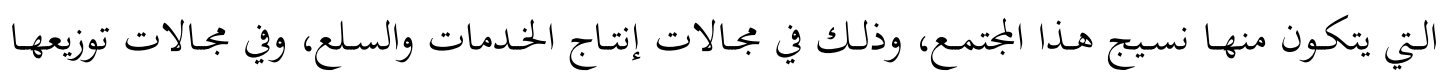

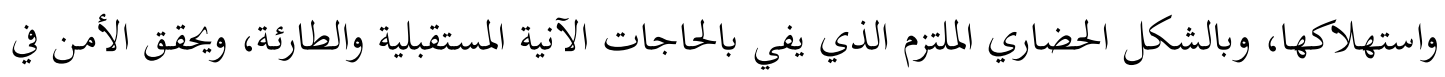

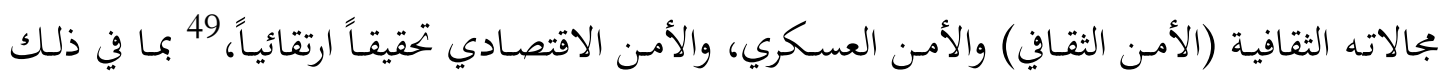

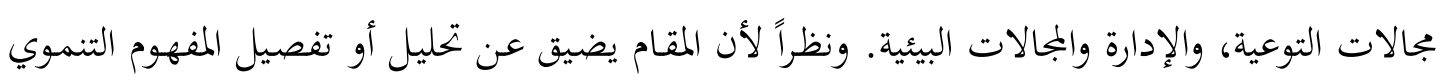

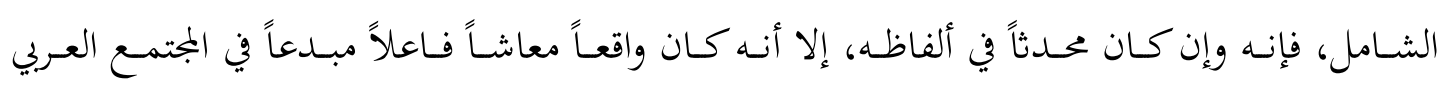

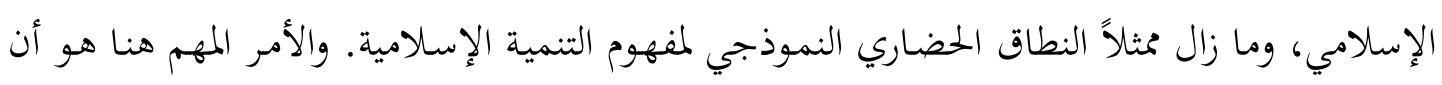

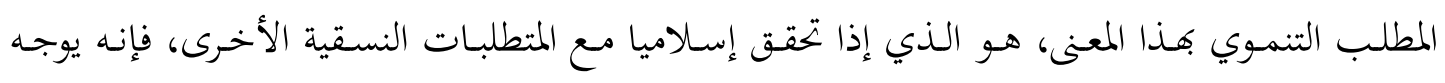

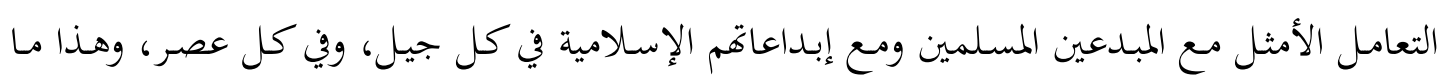
يمكن تسميته إدارة الإبداع في الإسلام.

خاتمة:

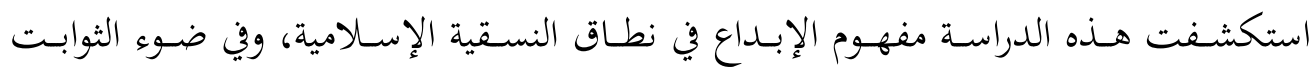

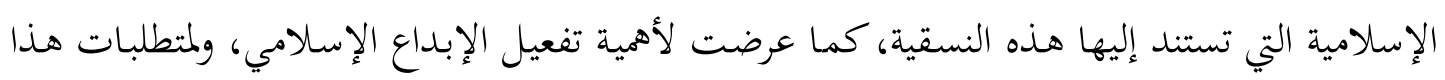

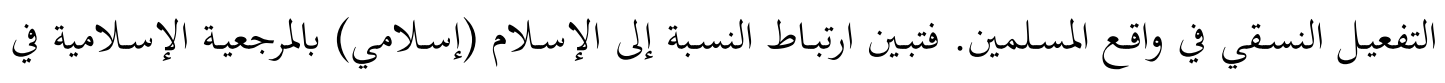
تحديد المفاهيم وفي تحقيق هذه النسبة وفي تأصيلها. وارتباط تحديد المفاهيم وتحقيق أسلمتها (إسلاميتها)

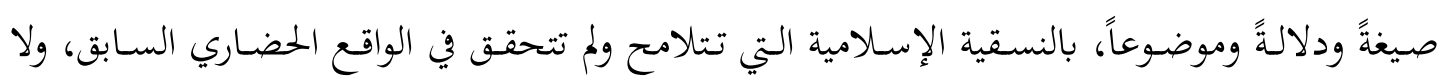

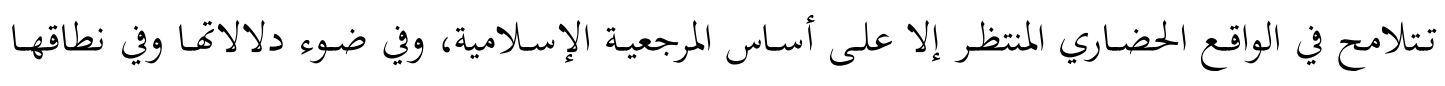

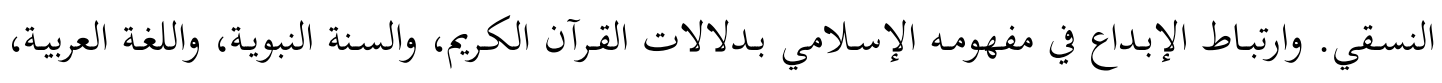

49 النشاط الارتقائي هو الذي يتقل من المستوى الحسن إلى المستوى الأحسن (الباحث). 
لغة الإسلام، ارتباطاً نسقياً في أبعاده التنظيرية، كما في أبعاده التطبيقية التي تتحرك ارتقائياً في مستويات

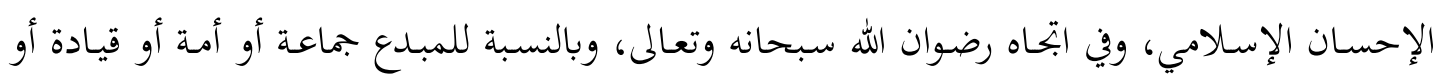
مجتمعاً. أمـا الإبـاع النسقي الإسلامي فمـن أبرز الوسائل الإسلامية في توجيه طاقات الأمة، وفي وقاية مسيرتا عقيدة وثقافة وحضارة وتربية ولغة، ويف حمايتها من التخلخل الداخلي، ومن التغلغل الوافد الإند

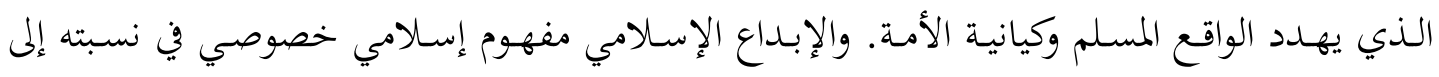

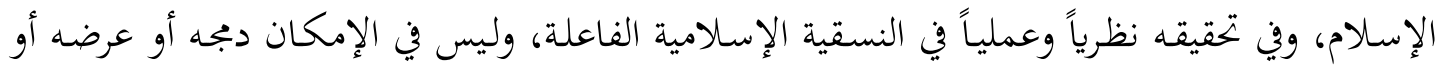

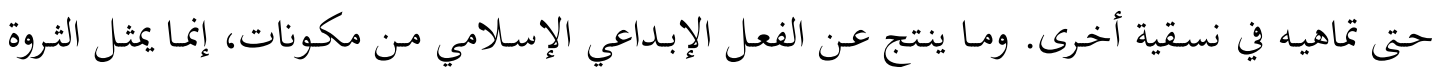

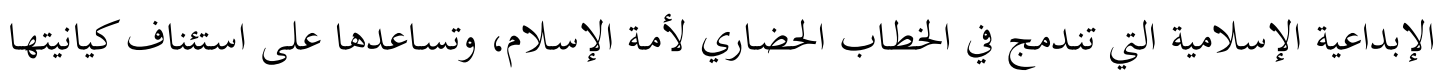

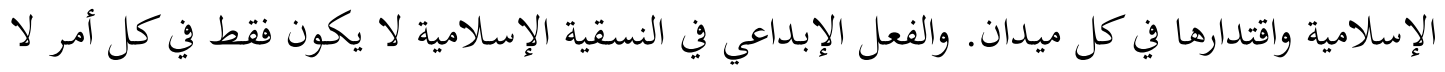

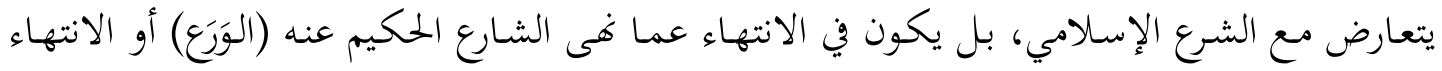

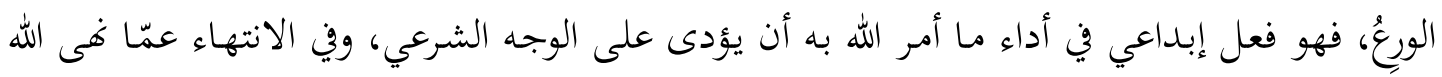

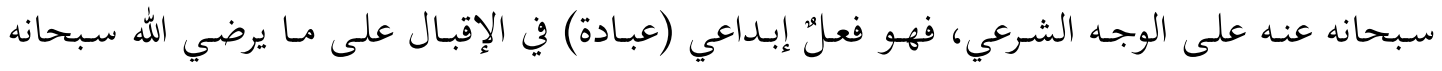
وتعالى، وفي ترك ما يغضبه جل وعلا.

كما أن الإبداع في النسقية الإسلامية يحترم العلاقة الإسلامية بين الوسيلة والغاية؛ إذ الوسيلة في

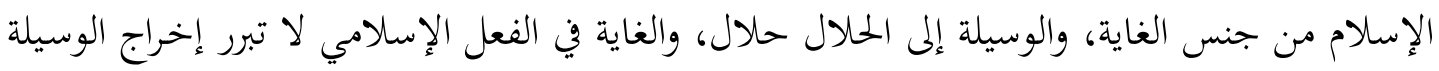

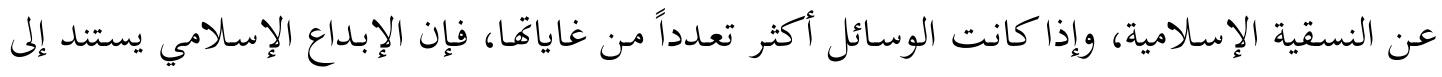

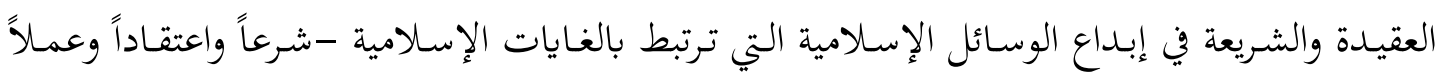

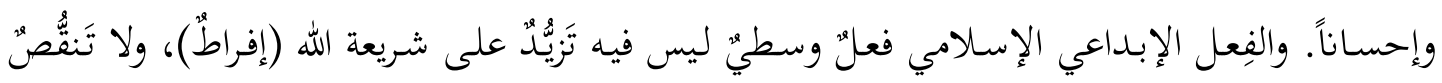

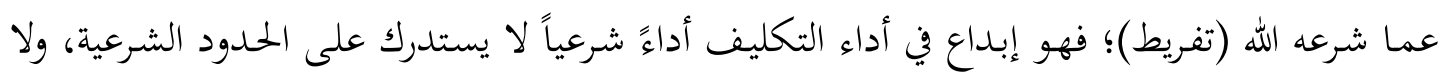

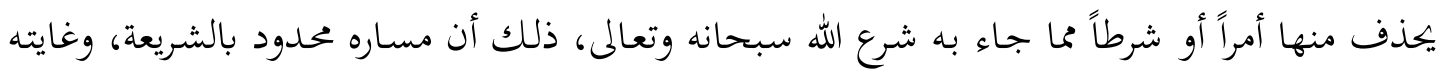

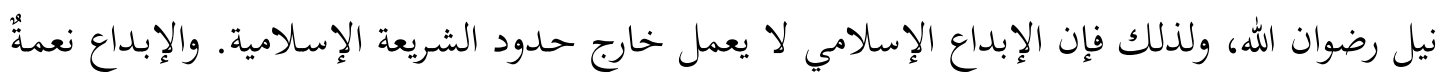

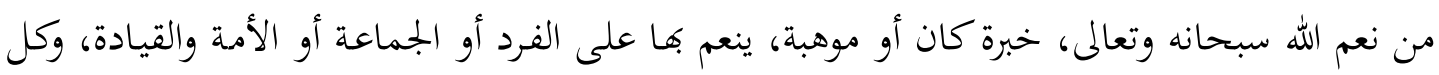

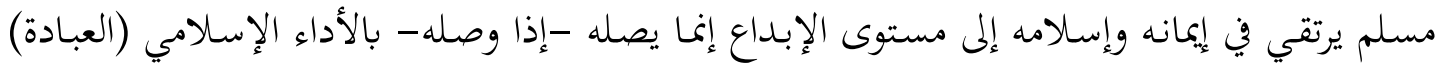

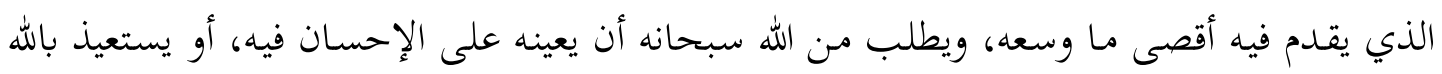

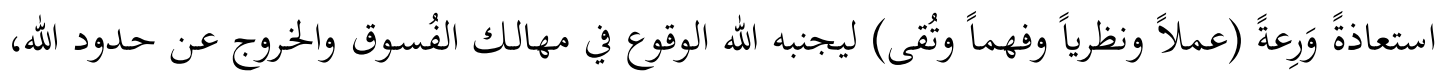


استعاذةً يتمثل فيها التعوذ الإبداعي الذي يرضاه الله سبحانه. كما يفترض الفهم الإسلامي أن توظف

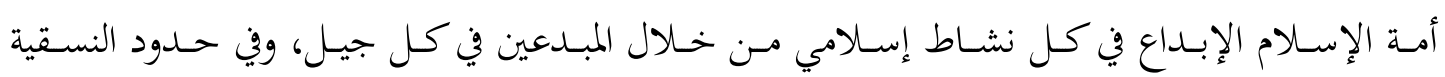

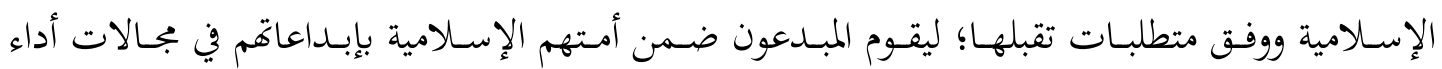

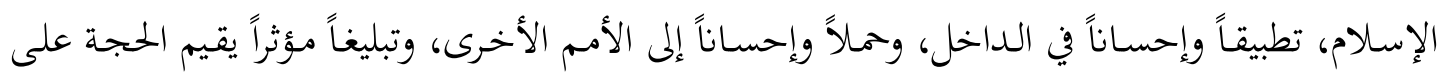

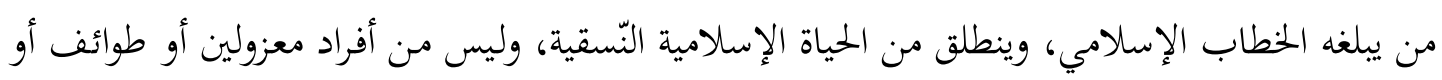

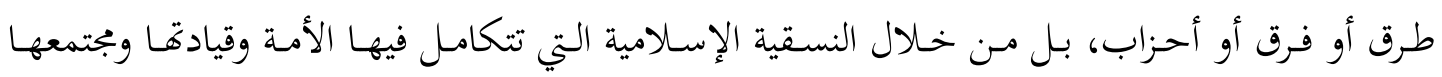

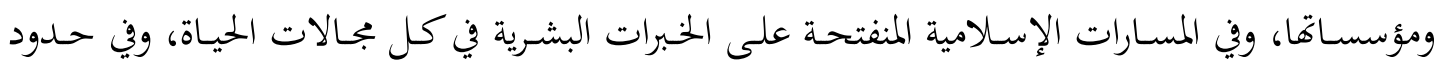
الثوابت الإسلامية.

أما مسارات الإبداع الإسلامي التطبيقية، فتتمثل في: المسار الوقائي، حيث يعمل الإبداع المهتدي

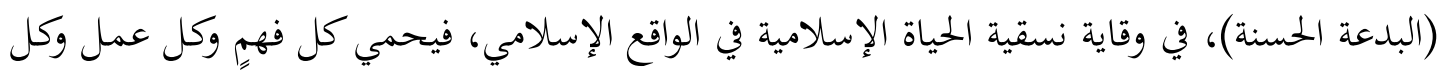

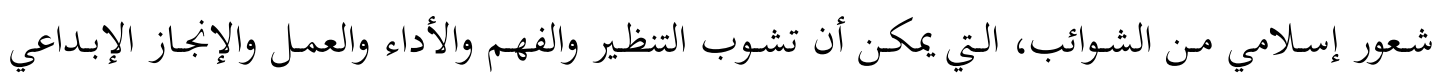

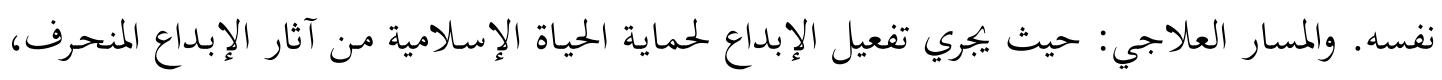

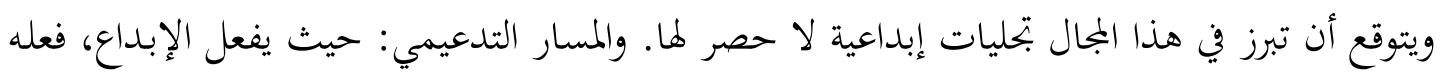

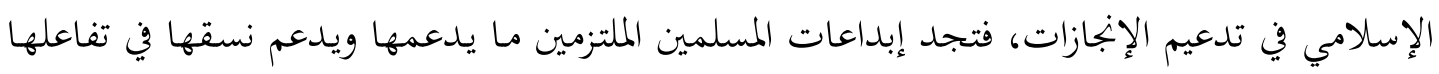

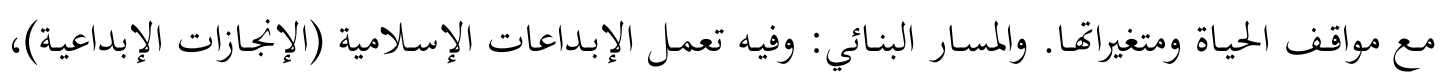

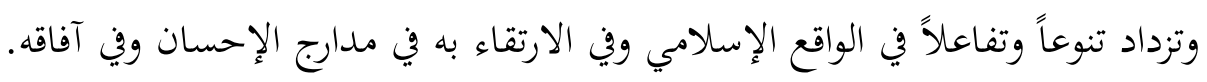

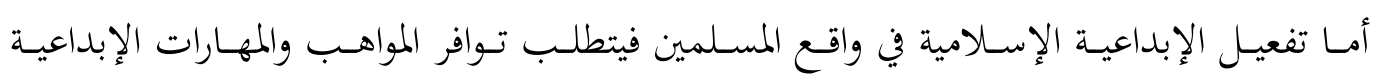

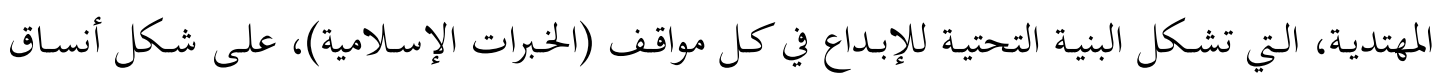

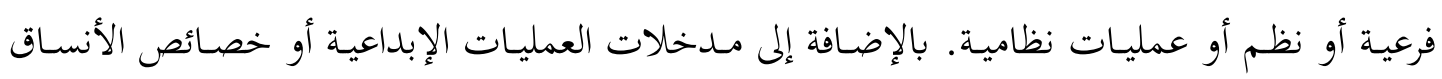

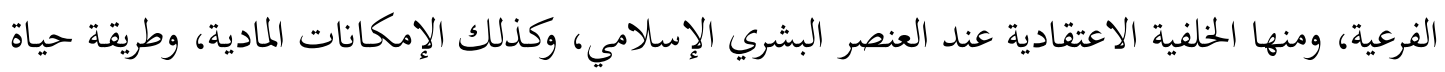

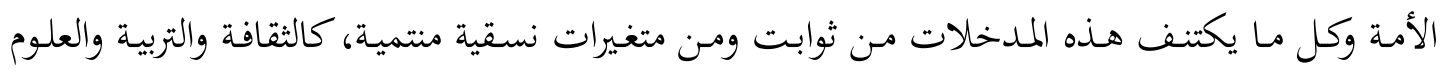

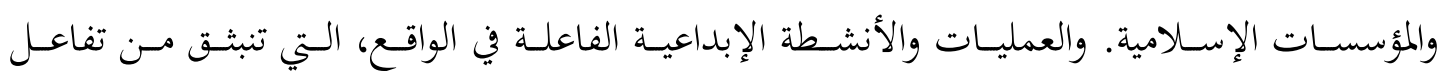
المدخلات في مواقف الحياة مع الأنساق الإسلامية الفرعية.

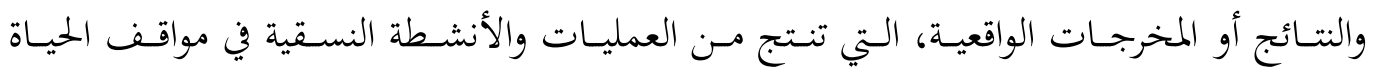

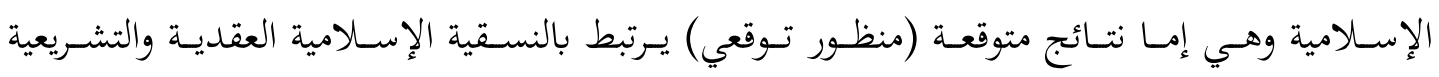

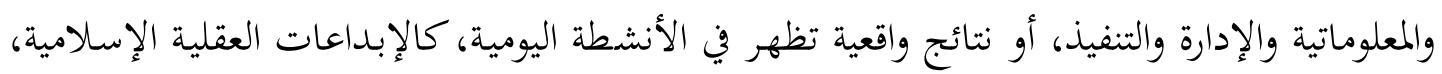


أو الخبرات الجديدة، أو الممارسـات التنموية، التي ترتقي بأداء الأمـة في إنتاج الخـدمات والسلع، وفي

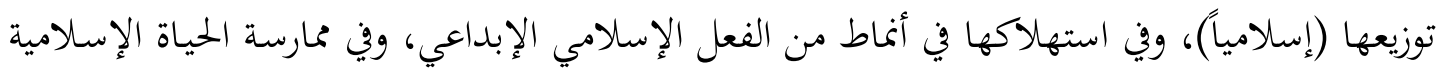

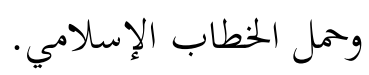

ويشيرُ التفعيل الإسـلامي للنشاط الإبـاعي إلى متطلبات نسقية مـن المتوقع أن تتوافر في الواقع

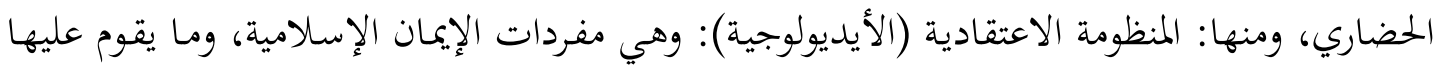

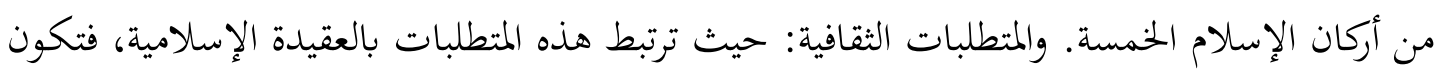

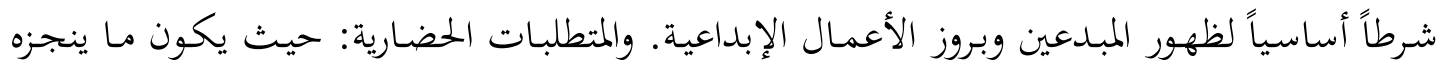

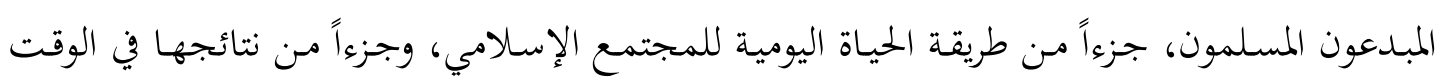

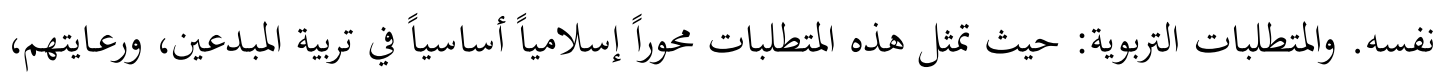

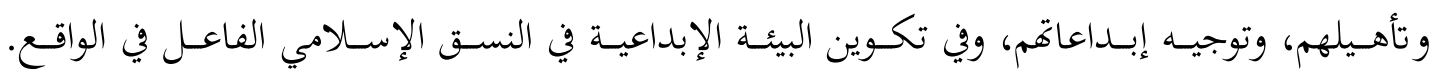

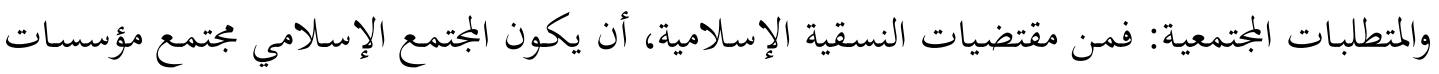

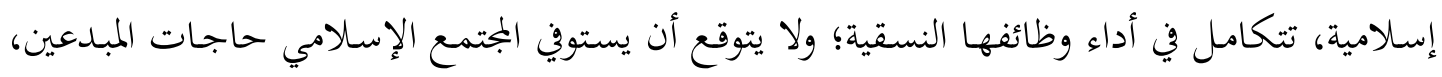

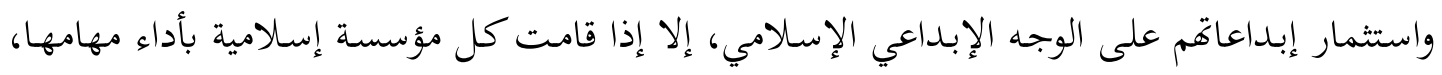

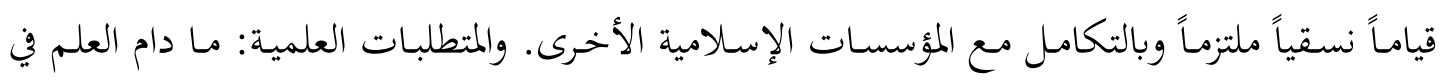

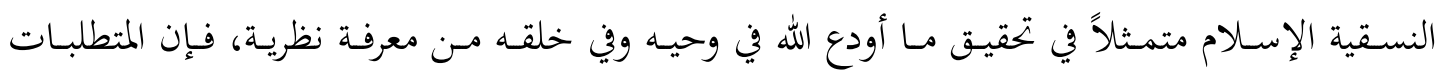

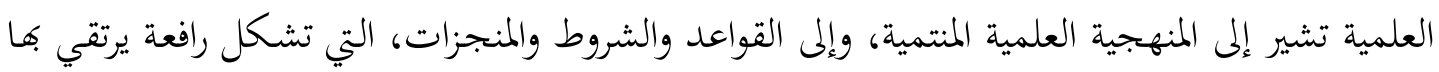

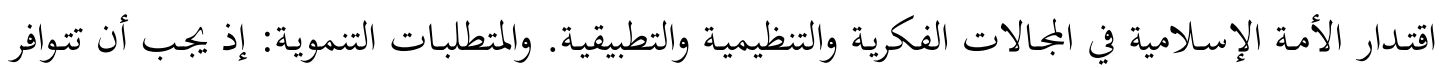

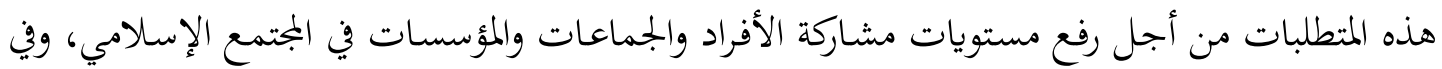

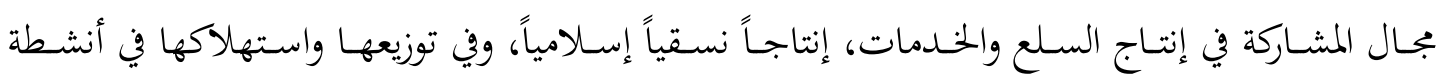

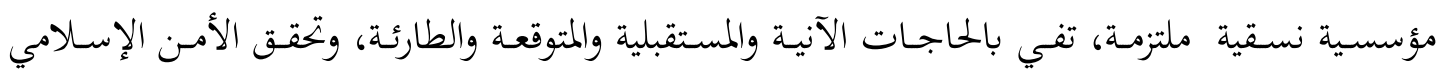
الشامل تحقيقاً ارتقائياً في نطاق النسقية الإسلامية.

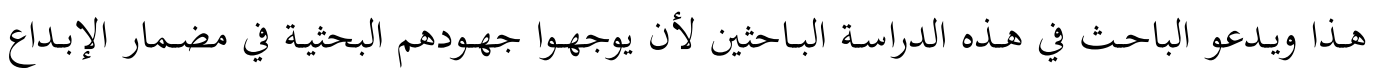

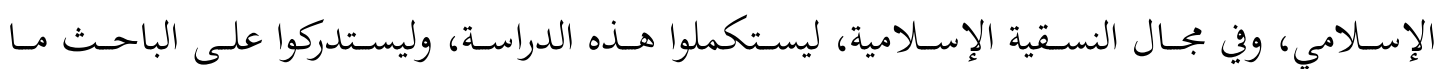
يكتشفونه من استدراكات وثغرات. 